\begin{abstract}
UNIVERSIDADE DE SÃO PAULO
ESCOLA DE ENFERMAGEM DE RIBEIRÃO PRETO

PROGRAMA INTERUNIDADES DE DOUTORAMENTO EM ENFERMAGEM
\end{abstract}

Clícia Valim Côrtes Gradim

\title{
SEXUALIDADE DE CASAIS QUE \\ VIVENCIARAM O CÂNCER DE MAMA
}

RIBEIRÃO PRETO

2005 


\title{
Clícia Valim Côrtes Gradim
}

\section{SEXUALIDADE DE CASAIS QUE}

\section{VIVENCIARAM O CÂNCER DE MAMA}

\author{
Tese apresentada ao Programa de \\ Doutorado Interunidades da Escola de \\ Enfermagem de Ribeirão Preto da \\ Universidade de São Paulo para obtenção \\ do Título de doutor em Enfermagem na \\ linha de pesquisa Sociedade, Saúde, e \\ Enfermagem.
}

Orientadora: Prof $^{\mathrm{a}} \mathrm{Dr}^{\mathrm{a}}$ Ana Maria de Almeida

\section{RIBEIRÃO PRETO}


AUTORIZO A REPRODUÇÃO E DIVULGAÇÃO TOTAL OU PARCIAL DESTE TRABALHO, POR QUALQUER MEIO CONVENCIONAL OU ELETRÔNICO, PARA FINS DE ESTUDO E PESQUISA, DESDE QUE CITADA A FONTE.

\section{Gradim, Clícia Valim Côrtes}

Sexualidade de casais que vivenciaram o câncer de mama / Clícia Valim Côrtes Gradim; orientadora Ana Maria de Almeida. - Ribeirão Preto, 2005. 182 f. -

Tese (Doutorado) - Programa interunidades de Doutoramento em Enfermagem. Área de Concentração Sociedade, Saúde e Enfermagem - Escola de Enfermagem de Ribeirão Preto. Universidade de São Paulo.

1. Sexo no casamento. 2. Câncer de mama. 3. Relações de gênero. 4. Enfermagem I. Título. 


\section{FOLHA DE APROVAÇÃO}

Clícia Valim Côrtes Gradim

SEXUALIDADE DE CASAIS QUE VIVENCIARAM O CÂNCER DE MAMA

Tese apresentada ao Programa de Doutorado Interunidades da Escola de Enfermagem de Ribeirão Preto da Universidade de São Paulo para obtenção do título de doutor.

Área de concentração: Enfermagem

Aprovado: 1

\section{Banca Examinadora}

Profa $^{\mathrm{D}} \mathrm{Dr}^{\text {a }}$ Ana Maria de Almeida Instituição: EERP-USP

Assinatura:

Profa $^{\mathrm{D}}{ }^{\mathrm{a}}{ }^{\mathrm{M}}$ Marli Villela Mamede Instituição: EERP-USP Assinatura:

$\operatorname{Prof}^{\mathrm{a}} \mathrm{Dr}^{\mathrm{a}}$ Raimunda Magalhães da Silva Instituição: UNIFOR Assinatura:

Prof $^{\mathrm{a}}$ Dr a: Roselena Bazilli Bergamasso Instituição: EE-USP Assinatura:

Profo $^{\circ}$ Dr. Manoel Antonio dos Santos Instituição: FFCLRP-USP Assinatura: 


\section{DEDICATÓRIA}

Ao Antonio Carlos, meu companheiro, que me incentivou e esteve ao meu lado em todos os momentos, compartilhando a distância, os filhos, os afazeres domésticos, sempre de bom humor.

A Cíntia e ao Felipe, meus filhos, que aprenderam o estar longe e a participar de atividades fora do mundinho deles, que souberam dar força em muitos momentos.

Aos meus pais, Isaías e Débora que me ensinaram o caminho da leitura.

Aos meus familiares, que me incentivaram e me apoiaram para a realização desta trajetória, em especial ao meu irmão Plínio Valim Côrtes e a Eliana Araújo Côrtes pelo acolhimento em todos os sentidos que proporcionaram.

A Débora e a Neuza, minha mãe e minha sogra, mulheres que viveram em épocas diferentes e que me mostraram o viver com o câncer. 
AGRADECIMENTOS

À Dra. Ana Maria de Almeida, minha admiração e respeito pelo seu saber e por me proporcionar o caminhar por novos caminhos.

Meu muito obrigada! 
Aos casais que participaram do estudo e que compartilharam comigo o seu lar, o seu saber, as suas dúvidas, os seus medos e a sua intimidade. 


\section{Agradecimentos}

Ao Departamento de Enfermagem da Escola de Farmácia e Odontologia de Alfenas/Centro Universitário Federal de Alfenas - Efoa/Ceufe, por minha liberação e pelo apoio durante o Doutorado.

Ao Programa Interunidades de Doutoramento em Enfermagem, nas pessoas da Profa ${ }^{\text {Dra }}{ }^{\mathrm{a}}$ Maria das Graças Bonfim de Carvalho e da Dra ${ }^{\mathrm{a}}$ Márcia Caron Rufino, pela acolhida calorosa e por ter acreditado em meu potencial.

Ao Núcleo de Ensino, Pesquisa e Assistência na Reabilitação de Mastectomizadas - REMA pela oportunidade de conhecer e participar desse grupo.

À Maria Antonieta Spinoso Prado e a Lenita Lopes Guiddorizze que sempre me apoiaram e me auxiliaram nos dados do REMA.

Aos profissionais do REMA, pelo companheirismo e por compartilharem o seu conhecimento.

Ao Conselho Nacional de Desenvolvimento Científico e Tecnológico - CNPq, pelo financiamento desta pesquisa.

As colegas de doutorado, que me mostraram outros caminhos $\mathrm{e}$ compartilharam a sua amizade e seu saber, que foram muitos, e dos quais prefiro não citar nomes, para não omitir ninguém.

Á bibliotecária Fátima dos Reis Goiatá, pela revisão das referências bibliográficas. 
A Deo e a Lourdes que sempre me atenderam com o maior carinho na Sala de Leitura da EERP/USP.

A todas as pessoas que, diretamente ou indiretamente, colaboraram para a execução deste trabalho. 
RESUMO

GRADIM, C.V.C. Sexualidade de casais que vivenciaram o câncer de mama. 2005. 182f. Tese (Doutorado) - Programa Interunidades de Doutoramento da Universidade de São Paulo, Ribeirão Preto, 2005.

Este é um estudo qualitativo que teve como objetivo conhecer junto a casais como a prática sexual é exercida após a mulher ter tido o câncer de mama, utilizando-se como referencial teórico as relações de gênero e, como metodologia, a Teoria Fundamentada em Dados. Por meio de entrevistas com nove casais, em que a mulher havia tido um diagnóstico de câncer de mama, obtivemos os dados que após análise permitiu a criação de dois diagramas; 1- a mama após o câncer: um olhar órgão que ficou afetado pela cirurgia, independente de ter ocorrido a mastectomia e que ficou longe das carícias no ato sexual. 2- O exercício da sexualidade dos cônjuges - nos homens o desejo sexual não diminuiu pela doença da esposa, mas as relações sexuais, sim, em razão de a mulher não estar disposta para o ato, principalmente no período de quimioterapia. As relações de gênero estiveram presentes no desenrolar de cada fase da doença e do tratamento, sendo que os papéis sexuais se mantiveram dentro dos padrões de nossa cultura. A desinformação masculina foi maior do que a feminina, mas os casais utilizaram alguma forma de enfrentamento. Os dados permitiram verificar que muitos mitos, como o abandono da mulher pelo homem, a nudez da mulher, o encerramento da vida sexual, não acontecem se o casal já tiver realizado uma construção de vida a dois.

Palavras chaves: sexo no casamento, câncer de mama, relações de gênero, enfermagem 
ABSTRACT

GRADIM, C.V.C. Sexuality of couples that lived the breast cancer. 2005. $182 f$. Theory (Doctorate) - Programs Inter Units of Taking the degree of doctor of the University of São Paulo, Ribeirão Preto, 2005.

This is a qualitative study that had as objective knows close to couples as the sexual practice is exercised after the woman to have had the breast cancer, being used as theoretical reference the gender relationships and, as methodology, the Grounded Theory. Through interviews with nine couples, in that the woman had had a breast cancer diagnosis, we obtained the data that allowed us the creation of two diagrams after analysis; 1 - the mamma after the cancer: a glance - organ that was affected for the surgery, independent of having happened the mastectomy and that it was far away from the caresses in the sexual action. 2 - the exercise of the spouses' sexuality - in the men the sexual desire didn't decrease for the wife's disease, but the sexual relationships, yes, in the woman's reason not to be disposed for the action, mainly in the chemotherapy period. The gender relationships were present in uncoiling of each phase of the disease and of the treatment, and the sexual papers stayed inside of the patterns of our culture. The masculine disinformation was larger than the feminine, but the couples used some form to face it. The data allowed to verify that many myths, as the woman's abandonment for the man, the woman's nakedness, the finishing of the sexual life, does not happen if the couple has already accomplished a life construction for two.

Key words: sex in the marriage, breast cancer, gender relationships, nursing 


\section{RESUMEN}

GRADIM, C.V.C. La sexualidad de parejas que vivieron el cáncer del pecho.

2005. 182f. La teoría (el Doctorado) - Los Programas Inter Unidades Doctoral de la Universidad de São Paulo, Ribeirão Preto, 2005.

Esto es un estudio cualitativo que tuve como objetivo conocer junto a las parejas como la práctica sexual se ejerce después de que la mujer haber tenido el cáncer del pecho, usándose como la referencia teórica las relaciones del género y, como la metodología, la Teoría Basó en los Datos. A través de las entrevistas con nueve parejas, en que la mujer había tenido un diagnóstico de cáncer de pecho, nosotros obtuvimos los datos que después del análisis nos permitieron la creación de dos diagramas; 1 - la mamá después del cáncer: una mirada - órgano que era afectado por la cirugía, independiente de haber pasado la mastectomía y que estaba lejos de las caricias en la acción sexual. 2 - el ejercicio de la sexualidad de los cónyuges - en los hombres el deseo sexual no disminuyó con la enfermedad de la esposa, pero las relaciones sexuales, sí, en la razón de la mujer no estar dispuesta para la acción, principalmente en el período de la quimioterapia. Las relaciones del género estaban presentes desenrollando a cada fase de la enfermedad y del tratamiento, y los papeles sexuales se quedaron dentro de los modelos de nuestra cultura. La desinformación masculina era más grande que el femenino, pero las parejas usaron algunas formas para enfrentarlo. Los datos permitieron verificar que muchos mitos, como el abandono de la mujer por el hombre, que la desnudez de la mujer, el acabamiento de la vida sexual, no pasa si la pareja ya ha logrado una construcción de vida a dos.

Las palabras llaves: el sexo en el matrimonio, cáncer del pecho, las relaciones del género, enfermería. 


\section{LISTA DE QUADROS E DIAGRAMAS}

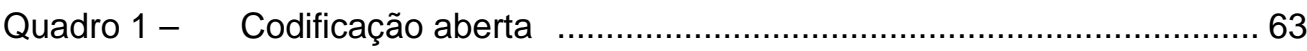

Quadro 2 - Formando categorias e sub-categorias ..................................... 64

Diagrama 1 - A mama após o câncer: um olhar ………………………….... 80

Diagrama 2 - O exercício da sexualidade dos cônjuges que vivenciaram o câncer

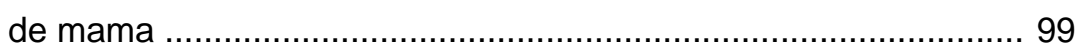

Diagrama 3 - Sexualidade dos casais que vivenciaram o câncer de mama: quebrando mitos 142

Quadro 3 -Contextualizando o câncer de mama ................................................170

Quadro 4 - A mama após o câncer de mama ...................................................172

Quadro 5 - O exercício da sexualidade dos cônjuges que vivenciaram o câncer de mama 


\section{LISTA DE ABREVIATURAS E SIGLAS}

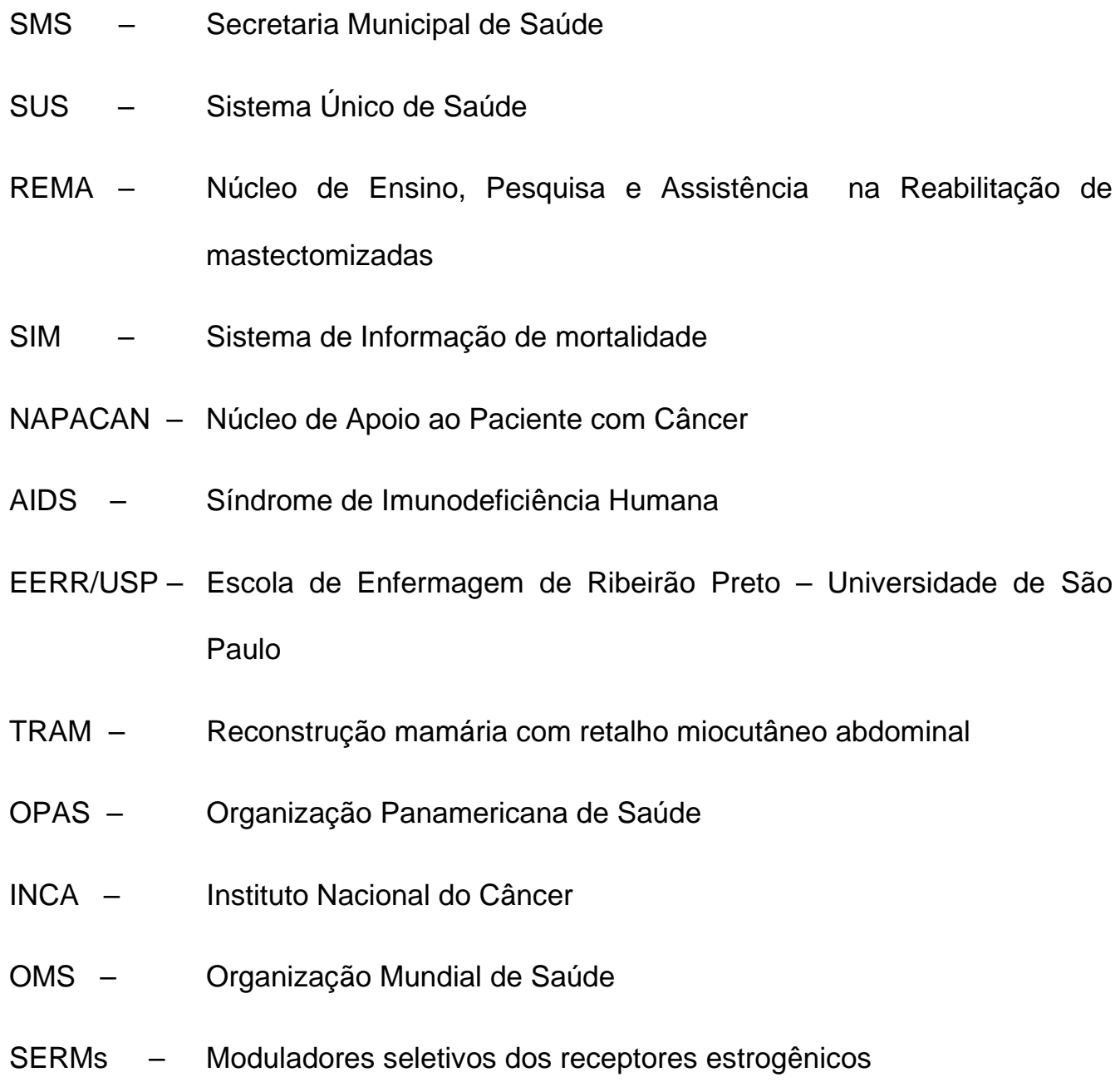




\section{SUMÁRIO}

RESUMO

ABSTRACT

RESUMEM

LISTA DE QUADROS E DIAGRAMAS

LISTA DE ABREVIATURAS E SIGLAS

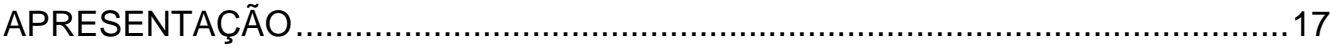

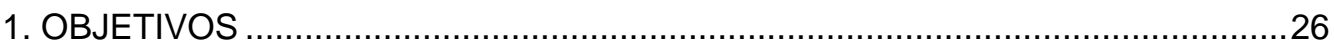

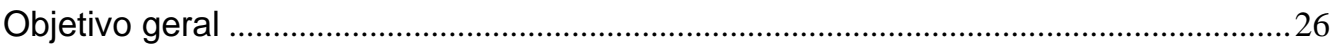

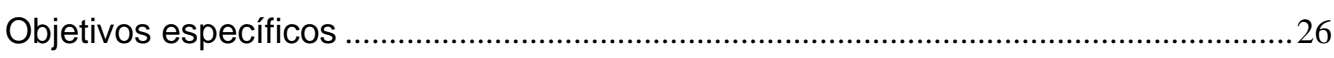

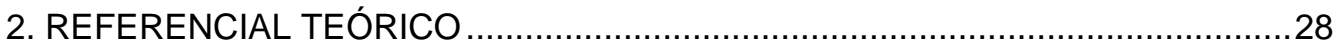

2.1. O câncer de mama e a sexualidade ..........................................................................2 28

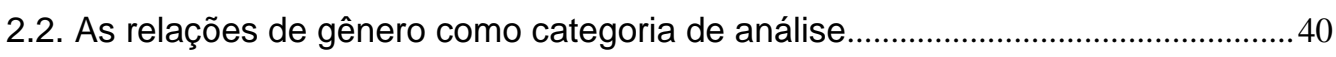

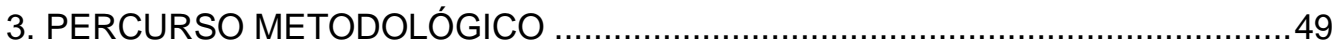

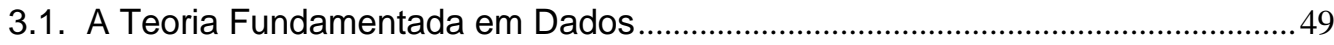

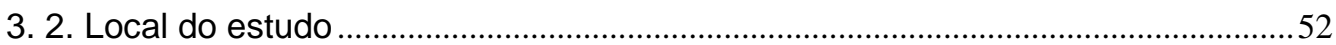

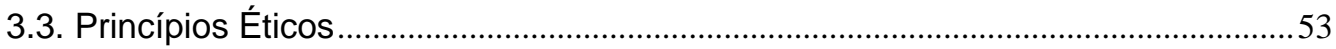

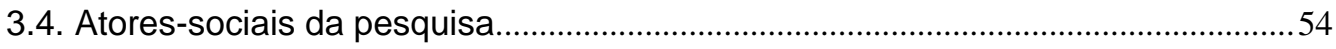

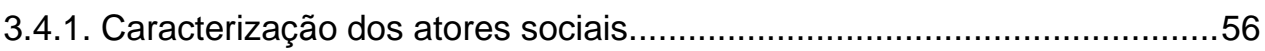

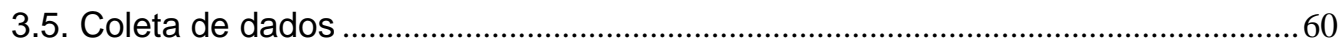

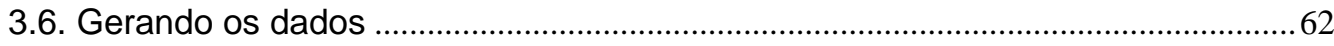

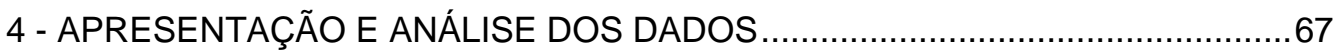

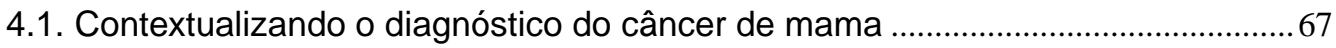

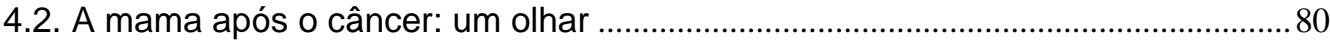

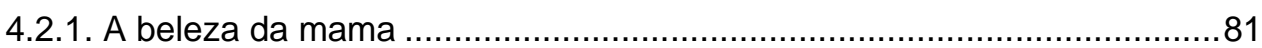

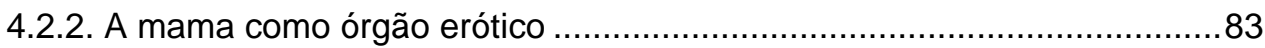

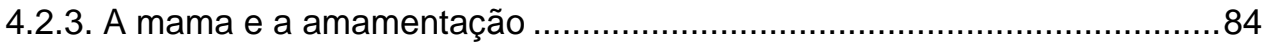

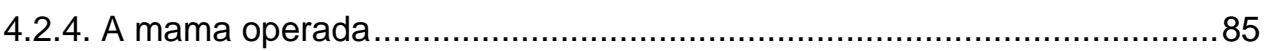

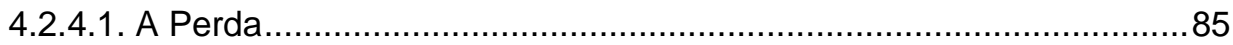

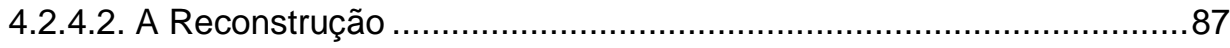

4.2.4.3. Percebendo as diferenças e tendo cuidado.....................................91 
4.2.4.4. O Toque 93

4.3. - O exercício da sexualidade dos cônjuges que vivenciaram o câncer de mama

.98

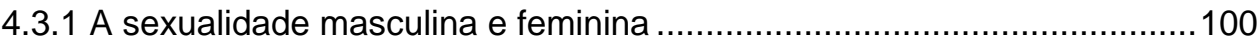

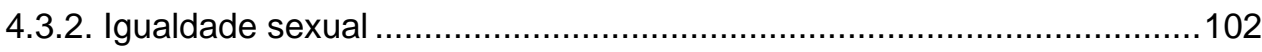

4.2.3. O Cuidado de manter a vida sexual .................................................... 108

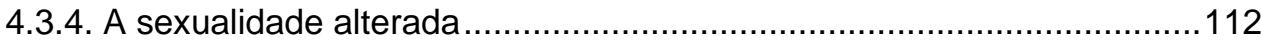

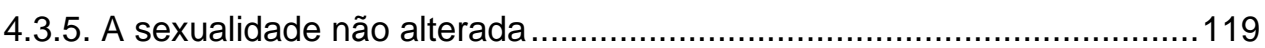

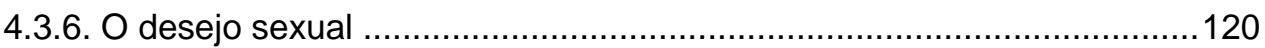

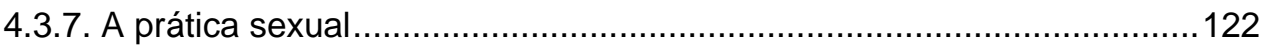

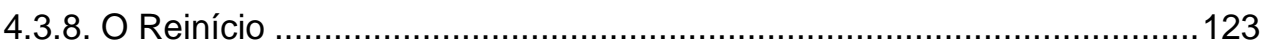

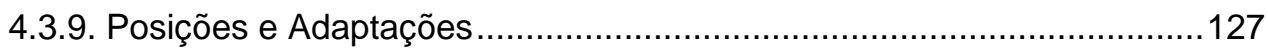

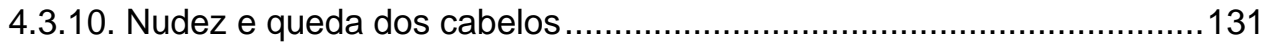

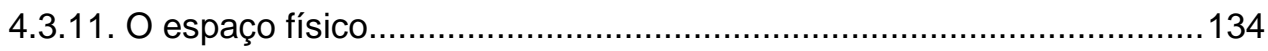

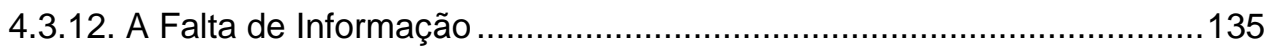

5. A CATEGORIA CENTRAL: A SEXUALIDADE DOS CASAIS QUE VIVENCIARAM

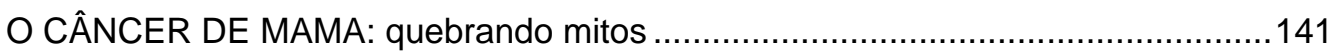

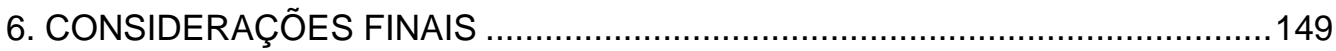

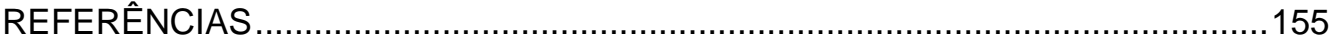

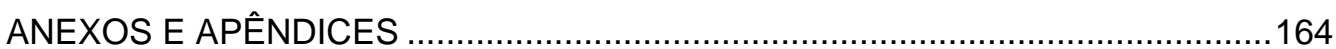




\section{Crônica de Mário Quintana}

Em maio de 1998, escrevi um texto que achava bonito o ritual do casamento na igreja, com seus vestidos brancos e tapetes vermelhos, mas que a única coisa que me desagradava era o sermão do padre:"promete ser fiel na alegria e na tristeza, na saúde e na doença, amando-Ihe e respeitando-Ihe até que a morte os separe?" acho simplista e um pouco fora da realidade. Dou aqui novas sugestões de sermões:

- Promete não deixar a paixão fazer de você uma pessoa controladora, e sim respeitar a individualidade do seu amada, lembrando sempre que ele não pertence a você e que está ao seu lado por livre e espontânea vontade?

- Promete ser amigo (a) e ser amante, sabendo exatamente quando devem entrar em cena uma e outra, sem que isso the transforme numa pessoa de dupla identidade ou numa pessoa menos romântica?

- Promete fazer da passagem dos anos uma via de amadurecimento e não uma via de cobranças por sonhos idealizados que não chegaram a se concretizar?

- Promete sentir prazer de estar com a pessoa que você escolheu e ser feliz ao lado dela pelo simples fato de ela ser a pessoa que melhor conhece você e portanto a mais bem preparada para Ihe ajudar, assim com você a ela?

- Promete se deixar conhecer?

- Promete que seguira sendo uma pessoa gentil, carinhosa e educada, que não usará a rotina como desculpa para sua falta de humor?

- Promete que fará sexo sem pudores, que fará filhos por amor e por vontade, e não porque e o que esperam de você, e que os educará pra serem independentes e bem informados sobre a realidade que os aguarda?

- Promete que não falará mal da pessoa com quem se casou só para arrancar risadas dos outros?

- Promete que a palavra liberdade seguirá tendo a mesma importância que sempre teve na sua vida, que você saberá responsabilizar-se por si mesmo sem ficar escravizado pelo outro e que saberá lidar com sua própria solidão, que casamento algum elimina?

- Promete que será tão você quanto era minutos antes de entrar na igreja?

- Sendo assim, declaro-os muito mais que marido e mulher, declaro-os maduros! 
APRESENTAÇÃO 


\section{APRESENTAÇÃO}

Desde criança ouvimos falar sobre câncer, mesmo desconhecendo o significado dessa patologia para as pessoas. Entretanto, logo entendemos que ela estava associada à morte, porque os adultos choravam e, às vezes, diziam que "fulano de tal", que estava com câncer havia morrido.

Isso para uma criança que não compreendia o significado da doença e da morte, era algo horrível, pois deixava todos muito abalados e a nós também, principalmente, quando perdemos um primo, que era nosso companheiro nos folguedos.

Desta primeira perda de um ente querido com câncer até chegar à vida profissional, muitas coisas se passaram e muitas perdas de familiares com câncer ocorreram.

Em minha formação como enfermeira, tive pouca experiência com pacientes com câncer, mas, mesmo nos serviços de saúde ou na assistência domiciliar, o câncer estava associado à morte porque tínhamos mais contato com pacientes em fase terminal, principalmente com aqueles que vinham para morrer perto da família, visto que estudamos em uma cidade do interior de Minas Gerais.

Depois de formada, já fazendo especialização em Enfermagem Obstétrica e Obstetrícia Social, iniciamos o contato na área de ginecologia com mulheres que 
Apresentação

apresentavam câncer e a ênfase ainda era assistência ao paciente em fase terminal. Isso se justificava visto que, há vinte anos, a formação do especialista, seguindo o modelo assistencial vigente enfatizava os aspectos curativos das doenças e, assim, a prevenção, a detecção precoce e a reabilitação eram relegadas a um plano secundário.

Quando iniciamos o trabalho como profissional de saúde, nos distanciamos desta área de atuação, pois durante 13 anos estivemos mais envolvida em atividades relacionadas à assistência à mulher no ciclo grávido-puerperal, mas pessoalmente vivia o cotidiano de ter familiares com câncer, inclusive minha mãe que teve câncer de mama. Como essa área nos instigava à reflexão, há doze anos iniciamos uma proposta de trabalho com ênfase na prevenção do câncer ginecológico e de mama.

Vários fatores contribuíram para essa opção, mas dois deles acredito terem sido preponderantes: termos identificado quão pouco é valorizada e implementada a atenção à saúde com vistas à promoção da saúde e a prevenção de doenças no País e termos convivido com pessoas muito jovens morrendo ou sendo mutiladas por uma doença que pode ser tratada e algumas vezes curada, quando diagnosticada precocemente.

Com a preocupação voltada para a prevenção e detecção precoce do câncer, implementamos junto com a equipe de enfermeiras da Secretaria Municipal de Saúde (SMS) de uma cidade mineira, a normatização para o exame de mama e a coleta de citologia oncótica do colo uterino. Criamos uma uniformização do atendimento no serviço, com registro de todos os exames preventivos em livro ata e um protocolo de atendimento foi proposto para as mulheres que apresentavam alterações sugestivas de neoplasia. Com essa proposta, tendo registro de todos os 
atendimentos realizados pelo Sistema Único de Saúde (SUS), foi possível o desenvolvimento de estudos descritivos que visavam identificar o perfil da população feminina que utilizava os serviços de saúde do Município.

Os resultados desses estudos permitiram organizar um serviço sistematizado em que todas as mulheres com alterações no exame de Papanicolau, com resultado a partir de NIC I, conforme a classificação de Bethesda, eram localizadas e convocadas para realização da colposcopia. Paralelamente ao controle do câncer cérvico-uterino, realizávamos orientações sobre o auto-exame de mama nas salas de espera de todos os ambulatórios. Essas atividades levaram a um aumento da demanda do serviço ginecológico do Município, que na época era centralizado em somente um ambulatório.

Em 1999 ocorreu uma reestruturação dos serviços de saúde no Município, e a assistência ginecológica foi descentralizada, passando a ser oferecida em todos os ambulatórios da cidade. Vilas Boas; Gradim (2002) relatam que, com a descentralização do serviço de ginecologia no Município, o número de atendimentos triplicou em relação ao período em que o serviço era centralizado.

Com o aumento da coleta da oncocitologia para prevenção do câncer cérvicouterino e a implementação de rotina nos serviços, foi possível observar que muitas mulheres não retornavam para buscar o resultado da citologia, fato observado pelas enfermeiras que, ao receberem os resultados dos exames, passavam para um caderno de registro da oncologia e aguardavam a mulher voltar para buscar o resultado. Com a verificação de que muitas mulheres não voltavam, a visita domiciliar passou a fazer parte da rotina do serviço como estratégia de busca ativa das mulheres faltosas com resultados de exames com alterações citológicas que necessitavam de exames diferenciais para diagnóstico de câncer. Assim, essas 
mulheres recebiam uma visita domiciliar, quando eram orientadas sobre a necessidade de outros exames e se fazia um agendamento da colposcopia, nessa oportunidade.

Essa estratégia possibilitou termos contato com as famílias e, mais especificamente, com os maridos e/ou companheiros. Observamos que, muitas vezes, os parceiros se tornavam o foco de nossa atenção e intervenção, especialmente quando sugeríamos que a parceira retornasse ao serviço para a continuidade da assistência.

Sinais de ansiedade eram uma constante observada entre os casais, mas a mulher recebia a notícia como uma necessidade de se cuidar e os parceiros solicitavam maiores esclarecimentos sobre a importância da prevenção e controle das lesões cérvico-uterinas para a saúde de suas companheiras.

Por outro lado, em situações em que havia um resultado positivo para o câncer, o companheiro era motivo de preocupação por parte da equipe, pois muitas vezes ele se sentia culpado, angustiado e cheio de dúvidas sobre o futuro da vida sexual do casal. Essas situações nos chamavam a atenção, porque o foco de atendimento era a mulher, ou melhor, a patologia da mulher, desconsiderando que quando um membro da família adoece, outros membros necessitam de apoio e orientações para não adoecerem também.

Essas percepções divergiam da realidade do modelo biomédico em que estávamos acostumadas a trabalhar, pois o foco de atendimento não era a família e, sim, a pessoa. Por outro lado, do ponto de vista sociocultural a mulher é tida como responsável pelo bem-estar da família e como cuidadora da mesma e, quando essa adoece, normalmente é delegado a outra mulher o cuidado. No entanto, estávamos 
nos deparando com situações novas, pois os companheiros questionavam, não somente o que aconteceria com sua esposa, mas também qual o papel que teriam nesse processo.

Verificamos que necessitávamos rever a nossa postura como profissional porque a visão que tínhamos do homem estava baseada nos conceitos oriundos da sociedade patriarcal em que a ele é designado o papel de provedor, forte, insensível, desprovido de espaço para manifestar sua intersubjetividade. Era, portanto, uma postura profissional que negligenciava momentos em que o parceiro poderia nos mostrar suas fragilidades, necessidades de explicitar emoções, inseguranças, temeroso perante uma situação desconhecida para ele.

Esse homem em quem começamos a prestar mais atenção era visto por sua esposa como alguém isento das responsabilidades tidas com femininas e preocupado apenas com a satisfação sexual. As preocupações explicitadas por elas eram: o que iria acontecer com ela? Como a sua família se comportaria, se ela se ausentasse durante o seu tratamento, visto que o tratamento adjuvante era realizado fora do Município? Suas angústias em relação aos companheiros centravam, principalmente, na preocupação ao darmos orientações sobre a necessidade de abster-se de relações sexuais durante um determinado período e a insegurança frente às necessidades sexuais do marido e o medo de ser traída.

Mesmo com essas inquietações que percebíamos, os atendimentos ainda estavam centrados nas mulheres e, não, no casal. Os trabalhos educativos realizados em feiras de saúde, palestras em centros comunitários visavam à população feminina, estimulando-a a realizar o auto-exame de mama e a prevenção do câncer cérvico-uterino, mas nada era orientado ao casal, não se falava da 
Apresentação

importância da participação do homem na prevenção de doenças da esposa e viceversa.

Estando envolvida nessas atividades de controle do câncer cérvico-uterino e mamário, e inserida num programa de doutorado, tivemos a oportunidade de conhecer o Núcleo de Ensino, Pesquisa e Assistência a Mulheres Mastectomizadas REMA, que funciona na Escola de Enfermagem de Ribeirão Preto da Universidade de São Paulo.

Esse núcleo atende mulheres com câncer de mama, procurando assisti-las após a cirurgia e durante todo o processo de reabilitação, buscando favorecer o crescimento e o desenvolvimento pessoal e o tratamento de seqüelas em mulheres que as apresentam, a prevenção de recidivas, o que me permitiu o envolvimento com essa área no atendimento às mesmas.

A experiência com essas mulheres com câncer de mama trouxe à tona aquele questionamento anterior sobre o envolvimento dos parceiros, visto que na assistência a elas tem sido comum o relato de pouca participação dos maridos, quer no tratamento, quer na recuperação como também a dificuldade dos mesmos em assumir novos papéis. Nas discussões feitas no grupo de apoio, observamos que surgiam questionamentos de como lidar com a sexualidade do marido, como fazê-lo compreender que ela estava necessitando dele, de seu carinho, de seu afago,etc. Percebíamos que tais questionamentos estavam ligados ao tipo de relacionamento que o casal construiu em suas vidas juntos. Percebíamos que o conteúdo de seus relatos nem sempre eram homogêneos entre as mulheres; uns extremamente negativos e, outros, abordavam a integração do parceiro no seu processo de adaptação. Percebíamos, então, que elas reconstruíam novos modelos de se relacionarem perante essa novel situação que era o câncer de mama. 
Essas observações nos levaram a refletir sobre se se faz a reconstrução do relacionamento conjugal do casal após o câncer de mama. Parece que não existe regra, mesmo em uma sociedade como a nossa, que sofre forte influência judaicocristã, na qual é estabelecido que o homem é o chefe da família. No entanto, não existe uma norma que defina claramente o papel de gênero que cada membro irá assumir, seja na sociedade ou no relacionamento a dois. Assim, cada casal constrói o tipo de relacionamento que deseja para si e o que irá fazer quando alguma situação vier a prejudicar essa relação.

Quando um deles adoece, o que se espera do outro e o que eles têm a oferecer? Quando se tem uma doença estigmatizante, como o câncer, e se este envolve um órgão tido como feminino como a mama, como o casal se percebe nessa nova realidade?

A mama é tida como um órgão erótico, apesar de que a sua valorização seja diferente para as pessoas e sua contextualização dentro do relacionamento sexual dependa do valor a ela dado, que pode ser diferente nas várias etapas da vida da mulher. Quando se tem um câncer e a mama sofre uma intervenção cirúrgica, esta traz alterações na sexualidade do casal?

No grupo de apoio do REMA, que é o espaço que as usuárias têm para discutir seus medos, conflitos, angústias e dúvidas sobre a doença, as questões de sexualidade têm surgido com freqüência. No entanto, essa temática surge geralmente nos minutos finais das sessões grupais e de forma acanhada, ficando as discussões, muitas vezes, sem aprofundamento. Preocupadas com essas necessidades apontadas pelas usuárias, os profissionais que atuam no REMA vêm desenvolvendo vivências sobre sexualidade e revelando boa aceitação pelas mulheres. Além disso, o REMA possibilita um atendimento individualizado de forma 
Apresentação

a favorecer a discussão sobre suas dúvidas e angústias. Esta nossa preocupação sobre a sexualidade das mulheres levou-nos aos prontuários das clientes que não estavam freqüentando o serviço, a fim de verificarmos se questionamentos semelhantes estavam registrados nos mesmos. Lendo os prontuários, verificamos que questões sobre a sexualidade sempre surgiram, tanto em relação à postura do parceiro, como quanto à própria sexualidade da mulher e o exercício desta, o que reforçou o nosso interesse nesta área e a importância da investigação.

Perante todas as alterações físicas e emocionais que as mulheres com câncer de mama vivenciam, a influência sobre a sua sexualidade e a escassez de estudos que buscam conhecer as conseqüências da dimensão da sexualidade na qualidade de vida do casal após um câncer de mama, reafirmamos a necessidade de estudos nessa área especialmente quando observamos que o desafio maior para o casal é construir espaços nos quais possam conversar sobre os seus medos, suas necessidades e não adotarem atitudes de afastamento, que quase sempre representam a idéia de que quem está doente não tem necessidades sexuais e afetivas. As alterações que o tratamento pode trazer sobre a sexualidade da mulher provocam um afastamento do casal nesta área?

Os questionamentos são muitos e como estes estão direcionados sempre para o casal, optamos por trabalhar com a sexualidade do mesmo. Assim, o presente trabalho pretende conhecer como a prática sexual do casal é exercida, quando a mulher tem um diagnóstico de câncer de mama. 


\section{OBJETIVOS}

\section{Objetivo geral}

Conhecer junto aos casais como a prática sexual é exercida após a mulher ter tido um câncer de mama.

\section{Objetivos específicos}

1) Identificar as alterações sexuais percebidas pelo casal durante o convívio com o câncer de mama.

2) Conhecer as estratégias de enfrentamento do casal frente as alterações sexuais percebidas.

3) Verificar as informações recebidas durante o tratamento sobre a sexualidade do casal. 


\section{REFERENCIAL TEÓRICO}

\subsection{O câncer de mama e a sexualidade}

O câncer é uma desordem celular em que há um crescimento desordenado das células, levando a alterações de funcionamento. Pode ocorrer em qualquer órgão e, quando não tratado precocemente, pode levar à morte. O câncer, culturalmente tem sido uma patologia associada à morte, e por isso, estigmatiza o seu portador que é visto como alguém que está próximo de morrer.

Até a década de 1980 os recursos terapêuticos para o tratamento do câncer eram escassos e seu portador tinha uma taxa de sobrevida baixa, principalmente porque o diagnóstico era feito tardiamente. Com o avanço das técnicas de diagnóstico, este passou a ser realizado mais precocemente e, com tratamentos mais eficazes, o câncer passou a ser considerado uma doença crônica degenerativa.

Como tal, apresenta uma evolução prolongada e progressiva, tendo um período de latência, uma fase assintomática prolongada, envolvimento de múltiplos fatores de risco e interação com o meio ambiente. Devido a esses múltiplos fatores, é uma patologia que acomete mais pessoas na fase adulta e com idade mais avançada (BRASIL, 1995). Por estar associado à idade avançada, reforça o fato de estar ligado à morte.

No Brasil tem sido possível conhecer o quadro de morbi-mortalidade pelo câncer, devido à implementação do SUS, que tem facilitado o acesso das camadas sociais excluídas aos serviços de saúde, aliadas às ações preventivas propostas 
pelo governo, centradas nas medidas de detecção precoce de neoplasias mamárias, de próstata e de colo uterino. Essas medidas têm como objetivo o diagnóstico em fases iniciais, levando a tratamentos mais eficazes e precoces, melhorando a qualidade de vida e, a partir dos resultados alcançados, tem sido possível a proposição de novas pesquisas com conseqüente incremento de artefatos tecnológicos de maior precisão em diagnósticos e tratamento, tendo relevância os recursos de diagnóstico de imagem.

Essas ações permitiram aumentar o atendimento ao usuário e, por outro lado, a implementação de sistemas de informação em saúde e a melhora do preenchimento dos atestados de óbitos. Esses dados permitiram aos órgãos centrais conhecer e configurar um quadro da realidade de saúde do País, podendo os mesmos planejar ações de maior impacto na formulação e implementação das políticas públicas na área da Oncologia.

Atualmente muitas pessoas acometidas por câncer, após tratamento, ficam curadas ou se mantêm na condição de portador de uma doença crônica controlada. Essas pessoas vivem como qualquer pessoa que tem uma doença crônica e os profissionais de saúde devem aprender a lidar com os usuários do sistema de saúde que referem histórias pregressas de câncer.

Dentre todos os tipos de câncer feminino, o de mama é conhecido desde a antiguidade e vem acometendo cada vez mais mulheres no mundo. No Brasil, excetuando-se os cânceres de pele, é a neoplasia maligna mais freqüente na mulher e, por seu diagnóstico ainda continuar sendo tardio, os índices de morbi-mortalidade têm sido elevados, levando a mutilações físicas e distúrbios psicológicos na mulher, assim como em toda sua família (RIBEIRO; GRADIM; SILVA, 1999; BRASIL, 2004). 
O câncer de mama é uma patologia mais freqüente após os 50 anos, mas, atualmente, o seu diagnóstico tem sido realizado em mulheres cada vez mais jovens. No REMA, de janeiro de 1998 a fevereiro de 2005, atendemos 221 casos novos. Destes, 129 foram de mulheres com idade inferior a 50 anos, sendo que 41 tinham menos de 40 anos e seis menos de 30 anos.

O Hospital do Câncer de São Paulo relata que, em um levantamento preliminar de agosto de 2003 a agosto de 2004, atendeu 16,8\% de mulheres com tumor mamário com menos de 30 anos, enquanto que o esperado seria de 5 a $7 \%$ (COLLUCCI, 2005).

Alguns fatores têm sido identificados para justificar a precocidade do acometimento do câncer de mama, entre eles, a tecnologia de diagnóstico atualmente disponível associada à maior conscientização das mulheres na busca dos serviços de saúde, quando identificam algum sinal ou sintoma na mama, o que tem permitido um diagnóstico em estágios mais precoces, e início do tratamento o mais cedo possível, com menos mutilação física e maior sobrevida.

O estadiamento do câncer de mama é um dos parâmetros utilizados para a indicação do tratamento. Quando indicado o tratamento cirúrgico, este poderá ser a retirada do nódulo, do quadrante(s), e da mama afetada, uni ou bilateralmente, acompanhada ou não do esvaziamento axilar. O tratamento cirúrgico pode ser complementado com a quimioterapia, a radioterapia e a hormonioterapia. Esses procedimentos têm permitido melhorar a qualidade de vida da mulher com câncer, podendo, em alguns casos, estabilizar a doença. Mas, mesmo com todos esses avanços, estima-se para o ano de $2005,49.470$ novos casos, com uma taxa de incidência de 53 casos por 100.000 mil mulheres. A taxa de mortalidade é de 10,4/100.000 mulheres no País, maior do que no período de 1979 a 2000 que era de 
9,74 (BRASIL, 2003). O aumento na taxa de mortalidade pode estar associado ao processo de municipalização da saúde e a implantação do sistema de informação de mortalidade (SIM). Esse sistema facilita monitorar as causas de morte devido à informatização dos dados. O SUS possui de 17 \% a 56\% de mamógrafos do País, tornando-se responsável por grande parte dos exames, resultando muitas vezes para o diagnóstico tardio e as altas taxas de mortalidade em decorrência das dificuldades de acesso das mulheres à tecnologia (BRASIL, 2004).

Com o diagnóstico tardio, ainda encontramos mulheres submetidas a cirurgias mais radicais, como a mastectomia e retirada da rede de linfonodos axilares. Essa cirurgia compromete aspectos estéticos e de auto-imagem, que pode ser acentuado com os tratamentos adjuvantes a que, com freqüência, a mulher é submetida como a quimioterapia, a radioterapia e a hormonioterapia que podem reforçar esses aspectos.

A quimioterapia é um tratamento que utiliza uma droga ou uma combinação delas com a finalidade de eliminar as células cancerosas e de prevenir metástases. Esse tratamento, apesar da eficácia, pode provocar alguns efeitos colaterais, tais como queda de cabelos, enfraquecimento de unhas, irritação e/ou sangramento gengival, pele ressecada, acne, prurido, diarréia, constipação, anorexia, irritabilidade, fadiga, desânimo, náuseas e vômitos, ansiedade, alteração no fluxo menstrual, amenorréia, diminuição ou perda do funcionamento das gônadas, diminuição da libido, ressecamento vaginal, diminuição dos glóbulos brancos e plaquetas, dependendo do tipo, da quantidade e do tempo da droga utilizada (BONASSA, 2000; FREITAS et al, 2001; NÚCLEO DE APOIO AO PACIENTE COM CÂNCER - NAPACAN [2002?]; BRASIL, 2003). 
Esses efeitos colaterais do tratamento podem ser percebidos pela mulher imediata ou tardiamente e mesmo que ela não venha a ter consciência de que muitos sintomas que ela sente estão relacionados à quimioterapia, como a queda do cabelo que é um fator que diminui a auto-estima.

A radioterapia consiste na irradiação de ondas de energia originada de material radioativo que visa a destruir as células tumorais. Utilizado, principalmente, após a década de 1980 como coadjuvante do tratamento do câncer mamário, apresenta também alguns efeitos colaterais como: leve eritema na região irradiada, anemia, alterações de paladar, mal-estar geral, fadiga, sonolência (BONASSA, 2000; FREITAS et al., 2001; VIANA; MARTINS; GEBER, 2001). Durante essa fase do tratamento, a fadiga e a sonolência levam as mulheres a se queixarem de um desinteresse por tudo.

A hormonioterapia também é um tratamento adjuvante que consiste no uso de hormônios que inibem o crescimento de tumores hormônios-dependentes. Em nosso meio, o tamoxifeno é a medicação de escolha. O seu uso tem sido atualmente questionado devido aos efeitos colaterais que causam como menopausa precoce, disfunções sexuais, ondas de calor e ressecamento vaginal, osteoporose, alterações do endométrio. Entretanto, em tumores estrógenos dependentes, o seu uso permite a diminuição de $27 \%$ da mortalidade (FREITAS et al., 2001; NAPALCAN, [2002?]; ROGERS; KRISTJANSON, 2002; FOLGUEIRA; BRENTANI, 2003).

Entretanto, o diagnóstico e o tratamento de um câncer de mama não se limitam à mama, pois a mulher é afetada física, emocional e socialmente bem como sua família e seu parceiro. Estudos vêm demonstrando que a mulher com câncer de mama pode ter sua auto-imagem alterada e sua recuperação depende de como ela percebe seu corpo, do apoio da família e dos amigos, do preconceito que se tem da 
doença, de como se lida com o problema (ALMEIDA, 1997; SILVA, 1994; ALMEIDA, 1997).

Em relação à mama, acresce-se o fato de que no mundo ocidental, ela é vista como um órgão representativo da feminilidade, tendo ênfase como órgão erótico, de prazer sexual, além de ser responsável pelo aleitamento de uma criança (YALOM, 1997). Isso é observado principalmente na publicidade, quando o corpo feminino é marketing para venda de qualquer produto e a ênfase que tem sido dada às mamas, sendo valorizadas as mamas grandes e firmes, que não é o perfil da mulher brasileira.

Dentro deste contexto de valorização da mama, o que ocorre quando essa é acometida por qualquer patologia e vem a sofrer intervenções cirúrgicas que a mutilem? Quais os sentimentos que o casal expressa sobre essa parte do corpo que tem importante papel na sexualidade?

Estudos têm demonstrado que mulheres que foram submetidas à mastectomia têm sua auto-imagem afetada, principalmente aquelas que têm companheiros. Esse sentimento pode ser evidenciado pela dificuldade de mostrar o corpo, como demonstrado no presente relato: "Tá certo que eu tenho meus dois seios, mas a gente fica meio assim... de tirar a roupa na frente de uma pessoa, do marido...(mastectomizada com reconstituição)" (RODRIGUES, 1999, p. 42). No mesmo estudo, algumas mulheres relatam aspectos positivos da doença, demonstrando que sua vida sexual melhorou após a cirurgia, ressaltando, entretanto, que mantinham um bom relacionamento com o marido anteriormente.

Um estudo sobre rede de apoio a mulheres com câncer de mama identificou dificuldades por parte dos parceiros em oferecer suporte social às suas esposas. Essas dificuldades eram relacionadas com a comunicação, a insegurança, em não 
saber lidar com a doença, a sensação de impotência, as dificuldades no manejo dos afazeres domésticos, o descobrimento acerca do momento de retomar as atividades sexuais, sendo que esses fatores influenciam na vida do casal dependendo do relacionamento que eles já tinham (BIFFI, 1998).

Perante tantas mudanças provocadas seja pela cirurgia e/ou pelo tratamento que leva a alterações fisiológicas nas mulheres, como lidar com a sexualidade do casal, considerando que o tratamento é variável em relação à evolução da doença e à modalidade do mesmo? Os profissionais de saúde devem lembrar que a sexualidade é inerente a todo o ser humano e, independentemente de raça, credo ou condição sócio-econômica, ela está presente e se manifesta no modo de ser das pessoas e, por isso, esta dimensão do cuidado deve ser contemplada na assistência.

No entanto, Pereira (2000) relata que os profissionais de saúde baseados somente nos conhecimentos de anatomia e fisiologia da reprodução humana que foram aprendidos na escola, não conseguem abordar com tranqüilidade e autoconfiança a mulher ou o casal perante as dificuldades de ordem sexual que este possam apresentar, quer seja sanando dúvidas ou orientando sobre como proceder perante os mesmos.

Em nossa sociedade, a visão sobre a sexualidade dos casais tem sido mais relacionada ao ato sexual e à reprodução do que a outras dimensões da relação conjugal, que vai desde o ajuste emocional entre eles, até a cumplicidade de afetos, olhares e carícias. É conhecer o outro no sentido corporal, emocional, psicológico e sexual e, neste sentido, essa compreensão da sexualidade é pouco discutida com a mulher ou com o casal que está passando por um câncer de mama. 
A sexualidade centrada no ato sexual e na reprodução é histórica e como tal, sua interpretação sofre influência da sociedade e da época. Os estudos de Kolodny; Master; Johnson (1982) acerca da relação sexual mostram que o ato sexual se divide em três tempos: excitação, platô e orgasmo e explicam cientificamente as sensações que milhares de pessoas têm, sem saber o porquê. Mas é Kaplan (1983) quem introduz a questão do desejo e vem complementar os estudos de Master; Johnson dizendo que se a pessoa não sentir desejo, o ato sexual não será satisfatório. Ela vem complementar estudos na área da sexualidade e traz novos conhecimentos sobre o relacionamento entre os casais, como a importância do toque, a cumplicidade do casal, além de desvendar a causa de várias disfunções sexuais e propor tratamento.

Essas descobertas mostram que as necessidades sexuais são individuais e que muitas queixas nesta área podem ser tratadas, levando o casal a ter uma vida íntima mais prazerosa, mesmo em situações de crise.

Kaplan (1983) explica que o desejo sexual é originado no cérebro em uma área que controla as emoções. Na infância, esses circuitos são relativamente inativos e, na puberdade, quando aumenta a produção de andrógenos, os centros sexuais do cérebro começam a ser ativados e, a partir daí, homens e mulheres experimentam o desejo sexual.

Kaplan (1983, p.73) revela que o desejo sexual é diferente nas mulheres e nos homens e que o sentir-se atraente sexualmente pode sofrer influências do meio socioambiental, como explicitados:

forças físicas e psicológicas podem afetar os centros sexuais e o desejo sexual de uma pessoa. Se você estiver doente, deprimido ou ansioso, excitado ou deprimido por certas drogas, se houver sido convencido que o sexo é mau, ou se houver sido magoado ou rejeitado, é provável que não sinta desejo sexual. Por outro lado, se 
você estiver em boas condições físicas, bem humorado, se achar que o sexo é bom, se estiver apaixonado por alguém que considere atraente, provavelmente se sentirá muito sexy.

Os estudos na área da sexualidade continuaram e foram complementados por outros na área da antropologia e sociologia, além da biológica, e os mesmos possibilitaram a ampliação de conceitos nessa área, como por exemplo, os estudos de Kinsey que observaram que a prática sexual entre os americanos não seguia o padrão cultural esperado de sexo reprodutivo e que muitos casais se declaravam bissexuais (GREGERSEN, 1982).

O termo sexualidade foi criado no século XIX, baseado em padrões de uma sociedade industrial e foi entendido como um conjunto de relações e ações das pessoas consigo mesmas e com as outras (LOPES; MAIA, 2000). Na atualidade, o conceito de sexualidade se ampliou e é:

sem dúvida, mais extenso e complexo do que as representações circulantes de homem e mulher, macho e fêmea, masculino e feminino. No entanto, parece ser em torno dessas representações que se elabora grande parte dos discursos que têm construído nossa idéia de sexualidade (VILELA; ARILHA, 2003. p.100).

Entretanto, a concepção de sexualidade vem acompanhando o desenvolvimento da sociedade e como tal sofrendo influência na determinação dos valores relacionados a ela, ao que Foucault $(1988$, p. 36) relata que: "o que é próprio das sociedades modernas não é terem condenado o sexo a permanecer na obscuridade, mas sim o terem devotado a falar dele sempre, valorizando-o como o segredo".

Ao se falar sobre sexo, possibilitou-se configurar o seu exercício a sexualidade e o seu exercício no campo de patologias físicas ou psicológicas, no 
campo de intervenções terapêuticas ou de normatização, reforçando a idéia de que a mesma também é constituída de relações de poder. Fica, portanto, a sexualidade regulada não só pelos padrões sociais, mas também por aqueles que detêm o poder, no caso os profissionais da área da saúde. Estes acabam ditando conceitos do que é permitido ou não na esfera sexual e reforçam a filosofia de Foucault de que o saber é poder, passando a área da saúde a atuar também como um órgão regulamentador da sexualidade (FOUCAULT, 1988).

A visão sobre a sexualidade com que nos deparamos como profissionais de saúde, levam-nos a levantar questionamentos: será que a mulher com câncer de mama, com sua auto-imagem modificada, seja pela cirurgia ou pelas alterações decorrentes do tratamento adjuvante teme ser rejeitada? Como ela expressa tais sentimentos a seu parceiro? E, quanto a seu desejo sexual, há modificação? A doença, seus tratamentos e seqüelas influenciam na vida sexual do casal.?

Estudos revelam que a fragilidade proporcionada pela auto-imagem afetada da mulher com câncer de mama tende a dificultar seu relacionamento com as pessoas, levando-a a afastar-se dos amigos, dos familiares e muitas vezes do companheiro, pessoa com quem deveria ter mais intimidade. Dependendo da importância que ela confere às mamas, o relacionamento entre o casal pode ficar afetado, mas estudos apontam que há uma dependência da situação emocional que o casal tinha antes do diagnóstico da doença (SEGAL, 1994; WANDERLEY, 1994; ALMEIDA, 1997; BIFFI, 2003).

Quando a construção do relacionamento do casal é sólida, a dupla será capaz de conversar e divagar sobre tais sentimentos e lentamente irem reestruturando suas vidas, em todos os aspectos, inclusive no sexual. Segal (1994) relata que muitos casais não conversam sobre sexo, mas, após um tratamento de câncer, se 
quiserem reconstruir sua intimidade terão que criar um diálogo para se redescobrirem sexualmente, aprendendo a se conhecerem mútua e intimamente, descobrindo jogos e áreas erógenas de prazer, caso contrário, poderão se afastar cada vez mais.

As alterações na sexualidade de mulheres com câncer de mama têm sido relacionadas, principalmente, em conseqüência do tratamento quimioterápico. Os efeitos colaterais, entre elas a menopausa precoce, o ressecamento vaginal e a queda dos cabelos, fator relevante na alteração da auto-imagem, acontecem com freqüência. Entretanto, parece que mulheres que procuram informações sobre os efeitos colaterais do tratamento sobre a sua sexualidade e têm relacionamentos íntimos consistentes, conseguem se ajustar sexualmente mais rapidamente do que aquelas que não recebem informações sobre o tema (HORDEN, 2000; ROGERS; KRISTJANSON, 2001; WILMOTH, 2001).

Anllo (2000) relata que o ajustamento sexual da mulher com câncer de mama não se dá de forma igual para todas as acometidas. Segundo a autora, o impacto maior está mais relacionado à realidade de ter um câncer do que à perda da mama em si. Fatores como a importância dada à sua aparência, à diminuição da função ovariana devido à quimioterapia, ao impacto do diagnóstico inicial, à idade ao diagnóstico, ao medo do abandono e ao seu papel na família devem ser pesquisados para orientações sobre problemas na sexualidade. Aponta, ainda, a importância de o profissional de saúde orientar ou encaminhar o casal a um terapeuta sexual no primeiro ano de tratamento.

Corbellini (2001) relata que, para mulheres com câncer de mama, são de extrema importância durante o tratamento o apoio e carinho do marido e/ou 
companheiro. Assim, sentir o companheiro mais próximo, transmitindo confiança e afeto faz com que elas consigam vencer a doença.

Holmberg et al. (2001) relatam em um estudo piloto com mulheres que tiveram câncer de mama e seus maridos, que o foco de preocupação sobre a doença e suas conseqüências entre homens e mulheres são diferentes. Enquanto as mulheres estavam preocupadas com a perda da mama, dos cabelos e com sintomas provocados por alterações hormonais, os homens se preocupavam com a perda potencial da parceira e o medo e ansiedade associados a essa perda. A preocupação com o relacionamento sexual apareceu em segundo lugar, independentemente do gênero, e ambos relataram a importância da orientação na área sexual, após o câncer de mama.

Perante o exposto acima, iniciamos um levantamento bibliográfico e posterior leitura de trabalhos realizados sobre a sexualidade de portadoras de câncer de mama, seus parceiros e suas famílias. Os estudos encontrados reafirmam a importância da família como suporte, que a sexualidade da mulher pode ser afetada dependendo do tratamento, mas sobre a integração do casal e mesmo sobre os sentimentos do parceiro, como ele é afetado pela doença da esposa, pouca coisa tem sido relatada (ALMEIDA, 1997; ANLLO, 2000; BIFFI, 1998; WILMOTH, 2001; BIFFI, 2003). 


\title{
2.2. As relações de gênero como categoria de análise
}

Para conhecer e compreender as alterações que podem surgir, quando o casal vivencia um câncer de mama, as relações de gênero se tornam uma proposta em que é possível trabalhar os sentimentos e posturas do sexo masculino e feminino.

Fonseca (1996, p. 42) relata que as

\begin{abstract}
relações de gênero podem ser resumidas em três posições teóricas: a primeira tenta explicar as origens do patriarcado, a segunda, de orientação marxista, propõe uma abordagem histórica tentando encontrar uma explicação material para gênero ou propondo uma solução baseada nos sistemas duais, compostos pelos domínios do patriarcado e do capitalismo e a terceira, mais recente, dividida entre o pós-estruturalismo francês e as teorias anglo-americanas das relações de objeto, inspira-se nas várias escolas da psicanálise para explicar a produção e a reprodução da identidade de gênero dos sujeitos sociais.
\end{abstract}

As discussões sobre as relações sociais e condições de trabalho de homens e mulheres se acentuaram no último século, quando as mulheres passaram a lutar pelo direito do voto e por melhores condições de trabalho, principalmente as tecelãs, fatos que propiciaram a organização dos movimentos de mulheres, primeiro passo para o movimento feminista.

O movimento feminista no Brasil passa a ter maior visibilidade a partir da luta por direitos políticos, como o voto. Nos anos 1960 e 1970 durante a ditadura militar, o movimento de mulheres esteve presente nas lutas pela democratização e pela anistia no País. Por intermédio de suas representantes, o movimento participou da 
formulação de políticas públicas na área da saúde da mulher, direcionando para a integralidade da assistência e conquistando espaços governamentais, além de iniciar estudos sobre as relações de gênero (TELES, 1993, p. 15-16).

Esses estudos tiveram como foco de análise a situação da mulher no campo social buscando compreender a divisão social do trabalho, construindo uma lógica a partir da analogia do masculino versus feminino, trazendo à tona as condições de trabalho da mulher, o seu atendimento nos serviços de saúde, sua participação nos meios políticos, entre outros, com ênfase no meio ambiente, classe social e cultura da mulher (TELES, 1993; CHAUÍ, 1994; MURARO, 1995).

Incorporam o conceito de gênero não apenas como a diferença entre os sexos, mas também incluíram as relações sociais entre homens e mulheres e apontaram como os aspectos tidos como masculinos e/ou femininos são percebidos pela sociedade e discutidos em uma relação androcêntrica, em que as relações entre os sexos e os conflitos determinam e reforçam os papéis sexuais na sociedade (KAABER, 1995; MURARO, 1995; MURARO; BOFF, 2002).

Os estudos que incorporavam as relações sociais de gênero no Brasil mostraram uma fotografia da população feminina a qual desconhecíamos. Foi possível visualizar uma mulher trabalhadora, sem direitos trabalhistas, com problemas de saúde, submissa ao companheiro, e submetida à violência física e psicológica dentro da própria casa (MURARO, 1983; LOBO, 1991).

A visibilidade dessa situação deu elementos para que a mulher reivindicasse os seus direitos, obtivesse suporte, mostrasse a sua força no mercado econômico e social. Essa participação no mundo público desencadeou outras ações como a procura por serviços de saúde, a diminuição no número de filhos, um maior controle sobre a reprodução pelo aumento do uso de contraceptivos entre outras. Associado 
a mudanças sociais como o envelhecimento da população, o aparecimento de doenças como a AIDS, a liberdade sexual, o uso de tecnologias reprodutivas levou ao surgimento de estudos e políticas públicas que viessem a atender essa demanda e também compreender o papel do homem nesta mudança social (ARILHA, 1998).

Atualmente os estudiosos em gênero vêm buscando compreender como o papel de cada gênero em uma sociedade pode modificar as relações com o conjunto de valores culturais e fronteiras sociais. Com esse enfoque, Scott $(1995$, p. 86) amplia o conceito de gênero, afirmando que ele:

\begin{abstract}
é uma conexão entre duas proposições: (1) o gênero é um elemento constitutivo de relações sociais baseadas nas diferenças percebidas entre os sexos e (2) o gênero é uma forma primária de dar significado às relações de poder. As mudanças na organização das relações sociais correspondem sempre a mudanças nas representações do poder, mas a mudança não é unidirecional. Como elemento constitutivo das relações sociais baseadas nas diferenças percebidas, o gênero implica quatro elementos interrelacionados: $1^{\circ}$ ) os símbolos culturais; $2^{\circ}$ ) os significados destes símbolos; $3^{\circ}$ ) a concepção de política bem como uma referência às instituições e $4^{\circ}$ ) a organização social e a identidade subjetiva dos indivíduos.
\end{abstract}

Diante das discussões fervorosas sobre a influência dos aspectos sociais na construção dos gêneros, estudos científicos sobre masculinidade iniciam-se nos Estados Unidos da América, na década de 1970 e tais estudos revelam que a masculinidade não é única ao longo da história da humanidade e que a mesma difere segundo a época, a classe social, a raça e a idade (BANDITER, 1993, p. 2728).

No Brasil, os estudos sobre o gênero masculino surgem no final dos anos 1980, e revelaram que culturalmente é esperado que o homem deveria ter os seguintes atributos: 
Ser forte, firme, seguro, autoconfiante destemido, ofensivo, provocador, agressivo, competitivo, dominador, líder, autoritário, intransigente, duro, frio, objetivo, racional, prático, independente, solitário, reservado, superficial, explorador, aventureiro, conquistador, capaz, vencedor, poderoso, ter vigor físico e sucesso financeiro, prover o sustento familiar e ainda ser capaz de manter intensa atividade sexual (ARENT, 1999, p. 121-122).

Diante de tantos adjetivos qualitativos para a figura masculina, passa-se a questionar o seu papel de macho na sociedade, se essa identidade que lhe é atribuída é verdadeira. Surgem, então, novos estudos mostrando que a masculinidade não é universal, que ela é ensinada e construída de acordo com a cultura, logo pode ser mudada (BADINTER, 1993).

Biddulph (2003, p. 6) relata que "o homem vem representando um grande papel que a sociedade determinou para ele e mantendo as aparências de ser o que esperam dele e fingem que tudo vai bem".

As mudanças sociais na sociedade são tímidas e ainda reforçam os modelos que foram aprendidos e preservados, passando de geração em geração sem muitas vezes serem discutidos, como na questão do homem ter que ser forte e não demonstrar suas emoções. Garcia (1998, p. 37) relata que:

[...] a pouca participação e a ausência de responsabilidade masculina no que se refere às práticas contraceptivas e sexuais, respectivamente, refletem uma construção social da masculinidade de desvalorizar o feminino e reforça valores associados à masculinidade dominante "hegemônica", como por exemplo, o distanciamento emocional, a agressividade e o comportamento de risco.

Vivemos em uma sociedade em que culturalmente o homem é tido como o esteio da família, responsável pelo seu sustento, pelo poder de tomada de decisão, logo, ele não deve demonstrar sinais de fraqueza uma vez que esse sentimento tem 
sido apontado como da esfera feminina. A mulher tem sido descrita como o sexo frágil, companheira do marido e deve ter qualidades femininas, como carinho, compreensão, dedicação ao lar e à família e intuição (FERREIRA, 1986; LEAL, 2004).

Assim, o casal constrói sua relação baseada em todos esses aspectos sociais aprendidos e, na situação de adoecimento de um, esses aspectos podem ser determinantes para fortalecer ou fragilizar o relacionamento dos mesmos.

Estudos sobre masculinidade têm derrubado muitos mitos sobre o homem, mostrando que qualidades como afetividade, capacidade de amar, participação no seio familiar, não são requisitos exclusivos do gênero feminino (NOLASCO, 1993; BIDDULPH, 2003).

Com um maior entendimento da influência da cultura sobre as relações sociais entre homens e mulheres, espera-se que o gênero masculino não seja visto apenas como provedor e que a mulher deixe de ser submissa e cuidadora do lar e da família e passe a dividir essas atividades com o seu parceiro. No entanto, sabemos que ainda vivemos em uma época em que ao gênero feminino cabem todas as responsabilidades domésticas. Questionamos, então, o que acontece na relação de um casal quando um dos parceiros fica doente? Como fica o casal diante de um diagnóstico de câncer, doença ainda estigmatizada e associada à morte? E quando essa doença atinge a mama, órgão feminino ligado à sexualidade, como o casal enfrenta a doença na perspectiva do relacionamento sexual do mesmo? Pouco sabemos sobre essa realidade frente ao casal.

A mulher com câncer de mama que se submeteu a uma cirurgia parcial ou total na mama, pode apresentar sentimentos de baixa auto-estima por ver sua imagem corporal modificada e isso vai depender da condição sócio-econômica, 
psico-espiritual e emocional da mesma, da família e do ambiente social, visto ser a mama, na sociedade ocidental, um dos atributos de beleza e feminilidade (MAMEDE, 1991; SILVA, 1994; ALMEIDA, 1997; BIFFI, 2003).

Silva (1994, p. 75) relata também que após a mastectomia a mulher:

Procura agir por si, criando sentido para a vida e imprimindo novos significados para suas relações inter e intrapessoal, a partir da reinterpretação de sua imagem corporal. A auto-estima e a imagem corporal constituem um processo dinâmico para o qual contribuem os sentimentos, emoções e atitudes das mulheres em relação a si e em relação ao corpo.

Quando surgem problemas, como a notícia de um diagnóstico de câncer, o casal faz uso dos padrões culturais esperados para cada gênero ou eles se reorganizam individualmente para se adaptarem a nova situação? Criam diálogos para discutir as barreiras que podem interferir na vida sexual do casal? Ou a forma de lidar com a sexualidade de ambos já construída ao longo da vida conjugal necessita sofrer alterações?

A compreensão acerca das relações de gênero vem dando a possibilidade de desconstruir padrões até então aceitos pela sociedade e buscar sua reconstrução. Entretanto, observamos que as relações entre homens e mulheres continuam, muitas vezes, repetindo os padrões culturais, nos quais prevalecem conceitos de que o mundo é masculino. Isso pode ser evidenciado pela afirmação de Bordieu (1998) de que a masculinidade está tão engendrada na sociedade que pode ser vista nos primeiros discursos das feministas que o faziam tendo como referência uma visão androcêntrica.

Para Bordieu (2001, p. 7), as mudanças sociais são determinadas pela própria sociedade. As escolhas não são individuais e, sim, determinadas por uma classe social, normalmente a dominante. A sociedade está diretamente ligada ao 
que ele denomina de poder simbólico que, segundo ele, "é esse poder invisível o qual só pode ser exercido com a cumplicidade daqueles que não querem saber que Ihe estão sujeitos ou mesmo que o exercem".

Assim, os sistemas simbólicos mantêm o poder porque são estruturados e aceitos pela sociedade que os reforçam, sendo que cada classe social o utiliza diferentemente, criando novos símbolos. Bordieu (2001, p. 9) conceitua que:

Os símbolos são os instrumentos por excelência da integração social, enquanto instrumentos de conhecimentos e comunicação, o que torna possível o consenso acerca do sentido mundial social que contribui fundamentalmente para a reprodução da ordem social: a integração lógica é a condição da integração moral.

Mas os símbolos são influenciados pelo habitus que

é o princípio gerador de respostas mais ou menos adaptadas às exigências de um campo, é o produto de toda a história individual, bem como, através das experiências formadoras da primeira infância, de toda a história coletiva da família e da classe (BORDIEU, 1990, p. 131). É essa espécie de senso prático do que se deve fazer em cada situação, o que chamamos, no esporte, o senso do jogo (BORDIEU, 1996, p. 42).

Como cada classe social pode ter o seu habitus, as mudanças influenciadas pela cultura e pelo momento histórico são, portanto, mutáveis e as relações de poder também.Portanto, uma classe dominada pode ser a dominante em determinados momentos, dependendo do habitus que ela defende.

Baseados nesse conceito de dominação, surgem estudos sobre a participação do homem na saúde reprodutiva sendo verificado que ela é muito pequena. Ele desconhece seu corpo, a prevenção de gravidez é tida como responsabilidade feminina e a fertilidade masculina é símbolo de potência e de sexualidade (ARILHA, 1998; ARENT, 1999). 
Nos últimos anos, porém, o homem vem se modificando, sendo que alguns têm assumido tarefas tidas como femininas, como cuidar dos filhos ou da casa, mas a organização do lar ainda é da mulher. Eles têm manifestado o desejo de compartilhar a responsabilidade na criação dos filhos e de assumirem a paternagem, não acreditando que perdem com isso, sua identidade de gênero, mas não é uma postura generalizada (RAMIRES, 1997, p. 114).

Para que a dominação simbólica funcione, é necessário que os dominados tenham incorporado as estruturas dos dominantes, de modo inconsciente. A tomada de consciência dessa situação pode desencadear um processo de mudança, mas isso não assegura uma mudança social (BORDIEU, 1996, p. 42).

As relações na sociedade têm se modificado, mas ainda permanece a lógica da economia e dos bens simbólicos, ou a essas extensões deste espaço, que são os serviços sociais (sobretudo hospitalares) e educativos, ou ainda aos universos da produção simbólica (áreas literária e artística, jornalismo, etc...).

Quando a mulher tem um câncer de mama, ela reorganiza seus sentimentos sob a perspectiva dela, feminina ou ela se reorganiza pensando na ótica das necessidades masculinas, do companheiro. O companheiro participa dessas reorganizações ou elas são individuais? Qual é o poder simbólico que persiste? 


\section{PERCURSO METODOLÓGICO}

\subsection{A Teoria Fundamentada em Dados}

Frente ao pouco conhecimento na área da sexualidade de casais que enfrentaram o câncer de mama, buscamos um referencial metodológico que permitisse desenvolver esse estudo, o que nos levou à escolha da metodologia da Teoria Fundamentada em Dados.

A Teoria Fundamentada em Dados é um método de pesquisa qualitativa que visa explorar processos sociais, presentes nas interações humanas desenvolvendo explicações chaves dos processos sociais ou estruturas destes, que são derivadas ou baseadas em dados empíricos. Essa Teoria deriva do estudo do fenômeno que está sendo representado, ou seja, desenvolve-se por meio da coleta sistemática de dados e da análise permanente dos mesmos. Portanto, dados coletados e análise mantêm uma relação recíproca um com o outro, ocorrendo simultaneamente, ou seja, entrevista realizada, ela é transcrita e analisada, visto que a teoria irá emergir desse processo de dados (STRAUSS; CORBIN, 1990; STREUBER; CARPENTER, 1995).

Strauss; Corbin (1990) relatam que a Teoria Fundamentada em Dados deve ter as etapas de coleta de dados e análise ocorrendo simultaneamente, o que permite a decodificação dos dados, a amostragem teórica, a formulação de memorandos e diagramas e por meio de comparação constante dos dados é possível a delimitação da teoria e a formulação do relatório final. Um diário de campo 
deve ser mantido para registrar fatos e ocorrências nas entrevistas que servem para complementação dos dados.

O tamanho da amostra nesse tipo de pesquisa é determinado pelos dados que são gerados e pela análise dos mesmos, até ocorrer a saturação. Na Teoria Fundamentada em Dados, a saturação se refere à necessidade de completar todos os níveis de códigos, quando não há novas informações conceituais disponíveis para indicar novos códigos ou para expandir os já existentes, aí, então, dizemos que a amostra está definida (STREUBER; CARPENTER, 1995).

STRAUSS; CORBIN (1998) relatam que as perguntas na teoria fundamentada em dados devem ser amplas e indicar o fenômeno a ser estudado. Relatam que se deve focalizar sobre o assunto que você quer e as perguntas devem ser orientadas para a ação e processo.

Seguindo a metodologia proposta, após cada entrevista, esta deverá ser transcrita e analisada, os pontos que não ficaram bem delineados devem sofrer aprofundamento com a retomada de pontos nebulosos com o entrevistado.

A análise dos dados na Teoria Fundamentada é formulada a partir da delimitação de códigos abertos, códigos axiais e códigos seletivos, memorandos ou diagramas que nomeiam e categorizam o fenômeno estudado. Nessa etapa, os dados são divididos em partes, examinados, comparados a partir de suas similaridades e diferenças e os questionamentos que respondem ao fenômeno encontrado nos dados, que geram a teoria (STRAUSS; CORBIN, 1990).

Assim, na análise dos dados, determinar-se-á o(s) núcleo(s) variável (is), que será (ão) os conceitos fundamentais para a geração da teoria. O núcleo variável, segundo Strauss (1987), deve apresentar seis características, sendo: 
1 - É evocado dos dados.

2 - É a ligação dos diferentes dados.

3 - É central e explica a variação dos dados.

4 - Tem implicações para a teoria mais geral e formal.

5 - É detalhado, ou seja, quanto mais detalhado ele venha a ser, mais a teoria avança.

6 - Permite variações máximas de análise.

Após a emergência do núcleo variável, é realizada a integração e a modificação de conceitos, por meio do uso de códigos teóricos e estruturas conceituais, dos memorandos, examinando todas as variações que resultam dos dados, sendo que a associação com a literatura seletiva permitirá escrever o relatório final da pesquisa.

Dentro dos princípios da Teoria Fundamentada em Dados, parte-se de questões norteadoras para definição do roteiro das entrevistas que neste estudo foi: Como a prática sexual é exercida pelo casal após a mulher ter tido um câncer de mama?

Partindo dessa questão, elaboramos um roteiro da entrevista com as questões abaixo relacionadas.

Qual o significado da mama para você?

- Você percebeu alguma alteração sexual durante o período do tratamento ou posteriormente?

- Vocês receberam informações sobre sexualidade durante o tratamento?

- O casal mantém diálogo sobre o assunto? Fale-me sobre isso. 
- Identificando alterações na prática sexual e desinformação acerca da temática, perguntamos aos homens se eles gostariam de participar de grupo de discussão.

\section{2. Local do estudo}

A pesquisa foi realizada no REMA - Núcleo de Ensino, Pesquisa e Assistência na Reabilitação de Mastectomizadas, que funciona na Escola de Enfermagem de Ribeirão Preto da Universidade de São Paulo.

O REMA atende mulheres mastectomizadas, três vezes por semana e tem como objetivos, segundo Mamede (1991):

- Prestar assistência integral à mulher com câncer de mama e aos seus familiares;

- Incrementar a formação de uma equipe multidisciplinar;

- Auxiliar no treinamento e na capacitação de profissionais, alunos de graduação e pós-graduação em Enfermagem e outras áreas de saúde;

- Prestar assessoria a outras instituições de saúde;

- Desenvolver pesquisa sobre câncer ginecológico e mamário;

- Desenvolver programa de prevenção na detecção precoce do câncer ginecológico e mamário.

Quando as mulheres procuram o REMA, recebem um atendimento individual, no qual é realizada uma consulta de enfermagem, procurando conhecer os dados pessoais, a história pregressa e atual da patologia e seu estado psicológico perante a doença. Um exame físico é realizado, verificando-se o local da cirurgia, o tipo de 
incisão, o processo de cicatrização, as aderências, as retrações, os processos infecciosos, o linfedema, enfim procurando identificar problemas que possam estar afetando o bem-estar da cliente e sua qualidade de vida.

Nesse primeiro contato, as clientes são convidadas e encaminhadas a participarem dos exercícios físicos, no sentido de estimular a circulação linfática dos membros superiores, auxiliando na prevenção do linfedema, tão comum nesta clientela, além de melhorar a mobilidade do braço homolateral à cirurgia. Após os exercícios, as mulheres participam de um grupo de apoio, que compreende um espaço para as mulheres discutirem dúvidas sobre o diagnóstico e tratamento, ansiedades, modos de enfrentamento e troca de experiências.

Às mulheres que apresentam linfedema superior a três centímetros são também oferecidas sessões de drenagem linfática com massagem manual associada ou não ao enfaixamento do membro afetado e, concomitantemente, é ensinado como manter e controlar o linfedema, utilizando a braçadeira.

Atividades lúdicas com as mulheres e seus familiares também são organizadas, esporadicamente, integrando-os assim à proposta da assistência integral.

\subsection{Princípios Éticos}

Os princípios éticos propostos pelo Conselho Nacional de Saúde em sua Resolução 196/96, que estabelece que as pesquisas envolvendo seres humanos devem atender às exigências éticas e científicas fundamentais, foram cumpridos. 
O projeto de pesquisa foi submetido ao Comitê de Ética em Pesquisa da EERP/USP, sendo aprovado na 49a Reunião Ordinária, em dezembro de 2002 (Anexo 1 e 2).

O termo de consentimento livre e esclarecido foi oferecido aos participantes da pesquisa, explicando o objetivo da mesma, garantindo o anonimato, permitindo a retirada do estudo a qualquer momento, sendo que a solicitação por escrito foi pedida à mulher e ao seu companheiro, que foram os informantes deste estudo (Apêndice 1 e 2).

\subsection{Atores-sociais da pesquisa}

Os atores sociais foram formados por casais cujas mulheres tiveram câncer de mama e que freqüentavam o REMA por ocasião da coleta de dados.

O primeiro contato foi realizado com as esposas nas reuniões do grupo de apoio, quando foi esclarecido o objetivo da pesquisa. O convite foi realizado em aberto no grupo e informado que maiores esclarecimentos seriam oferecidos individualmente.

Algumas mulheres nos procuraram e, após outros esclarecimentos, tais como finalidade da pesquisa, a técnica da coleta de dados, o sigilo, aspectos éticos e o local da entrevista, consultaram seus maridos, e após o consentimento de ambos, realizamos o primeiro contato com os homens via telefone.

Nesse contato, com os maridos era marcado o local, dia e hora em que poderiam nos receber para a entrevista. Assim as entrevistas com os maridos foram 
realizadas no domicílio dos participantes, com exceção de três, que foram realizadas respectivamente, no local de trabalho, no domicílio da pesquisadora e na Escola de Enfermagem de Ribeirão Preto. As entrevistas com as mulheres foram marcadas pessoalmente no REMA.

Utilizamos como critérios de inclusão, casais cujas mulheres tiveram câncer de mama, independentemente do tipo de cirurgia e tratamento coadjuvante, mas que não tinham outra patologia associada; não estavam em fase terminal da doença e, sim, em processo de adaptação em suas vidas, frente a essa nova realidade que é ser portador de um câncer. Entretanto, durante o processo das entrevistas, uma das mulheres apresentou uma metástase, mas resolvemos não excluí-la devido a já estarmos no processo de entrevistas.

Apesar das dificuldades de se falar sobre sexualidade inerentes aos tabus sociais acerca do tema, doze casais se propuseram a participar do estudo, mas, até o final do mesmo entrevistamos nove casais. Três casais não participaram, sendo um, pela presença de outra patologia com interferências maiores na sexualidade que do que o câncer, um, pela ocorrência de morte súbita de uma das mulheres e, o outro, pela desistência de um membro do casal.

Após a sexta entrevista de cada gênero do casal, verificamos que houve a saturação dos dados, mas optamos por entrevistar todos os casais que se propuseram a participar do estudo.

Os maridos foram identificados por nomes de jogadores de futebol e as mulheres por nomes de flores, escolhidos por eles. No entanto, para garantir a privacidade dos mesmos na apresentação, análise e discussão das falas, serão identificadas por (GM) de gênero masculino e (GF) de gênero feminino. 


\subsubsection{Caracterização dos atores sociais}

\section{Casal 1}

Genevildo, branco, 52 anos, ensino fundamental incompleto, comerciante, católico não praticante, casado há 10 anos, sem filhos no atual casamento, possui plano de saúde.

Rosa, negra, 46 anos, ensino fundamental completo, funcionária pública, católica, sem filhos, com plano de saúde, submetida a uma mastectomia tipo Madden, com reconstrução mamária simultânea com silicone aos 43 anos. Como tratamento coadjuvante, realizou 6 sessões de quimioterapia e 28 de radioterapia, não apresenta linfedema. No momento faz avaliação e controle da doença a cada 6 meses.

\section{Casal 2}

Ronaldo, branco, 37 anos, ensino médio incompleto, mecânico, católico não praticante, casado há 10 anos, sem filhos, dependente do Sistema Único de Saúde (SUS).

Lírio, branca, 42 anos, ensino superior incompleto, professora, católica, terceiro casamento, 3 filhos, submetida a uma nodulectomia com esvaziamento ganglionar da mama direita, com reconstrução da mesma aos 40 anos. Como terapia coadjuvante foram realizadas 6 sessões de quimioterapia, 28 de radioterapia e hormonioterapia. Não apresenta linfedema e, atualmente, faz controle e avaliação da doença a cada 6 meses. 


\section{Casal 3}

Raí, negro, 39 anos, ensino médio completo, auxiliar de enfermagem, católico praticante, casado há 15 anos, dois filhos, possui plano de saúde.

Tulipa, negra, 36 anos, ensino médio completo, do lar, católica, submetida a uma mastectomia esquerda com esvaziamento ganglionar axilar, com reconstrução imediata com retalho miocutâneo do músculo reto abdominal (TRAM) aos 34 anos. Como tratamento coadjuvante, realizou 6 sessões de quimioterapia e a hormonioterapia, não apresenta linfedema. No momento da entrevista, aguardava para fazer a segunda etapa da reconstrução mamária. Realiza o controle e avaliação da doença a cada 6 meses.

\section{Casal 4}

Rivelino, branco, 63 anos, ensino fundamental incompleto, aposentado, católico praticante, casado há 37 anos, 4 filhos, conveniado do SUS (Sistema Único de Saúde).

Orquídea, branca, 61 anos, ensino fundamental incompleto, do lar, católica, submetida a uma nodulectomia da mama esquerda com esvaziamento ganglionar axilar aos 59 anos. Teve como tratamento coadjuvante 6 sessões de quimioterapia, 28 de radioterapia e a hormonioterapia que utilizou por três meses e abandonou por apresentar efeitos colaterais severos. Não apresenta linfedema. Atualmente faz controle e avaliação da doença a cada 6 meses. 


\section{Casal 5}

Romário, branco, 52 anos, ensino fundamental incompleto, pintor, evangélico, casado há 25 anos, 3 filhos, dependente do Sistema Único de Saúde. (SUS).

Violeta, branca, 51 anos, ensino fundamental incompleto, funcionária pública aposentada, evangélica, submetida a uma quadrandectomia na mama direita com esvaziamento ganglionar axilar, aos 39 anos. Como terapia coadjuvante, submeteuse a 6 sessões de quimioterapia, 15 de radioterapia e utilizou hormonioterapia por 9 anos. Atualmente faz controle e avaliação da doença anualmente e não apresenta linfedema.

\section{Casal 6}

Leão, branco, 52 anos, ensino médio completo, comerciante, cristão, casado há 14 anos, sem filhos neste casamento, possui plano de saúde.

Margarida, branca, 48 anos, ensino superior completo, enfermeira, católica, sem filhos, com plano de saúde, submetida a uma mastectomia esquerda tipo Patey sem reconstrução mamária, aos 44 anos. Como tratamento coadjuvante, realizou 6 sessões de quimioterapia e 32 de radioterapia. Fazia o controle e avaliação da doença a cada 6 meses e, no momento da entrevista, estava submetendo-se a quimioterapia por ter apresentado uma metástase no pulmão, não apresenta linfedema. 


\section{Casal 7}

Garrincha, negro, 58 anos, ensino fundamental incompleto, auxiliar hidráulico, evangélico, casado há 5 anos, sem filhos neste casamento, com plano de saúde.

Flor de maio, branca, 54 anos, ensino fundamental incompleto, dona de casa, evangélica, filhos do primeiro casamento, com plano de saúde; submeteu-se a uma mastectomia esquerda tipo Patey com esvaziamento ganglionar axilar aos 53 anos. Como tratamento coadjuvante, realizou 3 sessões de quimioterapia pré-operatória e 6 pós-operatória e 28 sessões de radioterapia; não apresenta linfedema.

\section{Casal 8}

Zito, branco, 53 anos, ensino fundamental incompleto, supervisor de acabamento, transporte e produção, evangélico, casado há 27 anos, 2 filhos, com plano de saúde.

Primavera, branca, 46 anos, ensino fundamental incompleto, do lar, evangélica, sem plano de saúde, submeteu-se a uma nodulectomia da mama esquerda com esvaziamento ganglionar axilar aos 45 anos. Como terapia coadjuvante, realizou 9 sessões de quimioterapia e 28 de radioterapia. Atualmente faz controle e avaliação da doença semestralmente e não apresenta linfedema.

\section{Casal 9}

Cafu, branco, 53 anos, ensino fundamental incompleto, pedreiro, católico não praticante, casado há 15 anos, sem filhos no atual casamento, com plano de saúde. 
Petúnia, negra, 65 anos, ensino fundamental incompleto, do lar, católica praticante, filhos do primeiro casamento, com plano de saúde, submeteu-se a uma quadrandectomia da mama esquerda com esvaziamento ganglionar axilar aos 64 anos. Como terapia coadjuvante, realizou 6 sessões de quimioterapia e 28 de radioterapia. Atualmente faz controle e avaliação da doença semestralmente e não apresenta linfedema.

\subsection{Coleta de dados}

Para a realização deste estudo, a abordagem inicial ocorreu na participação da pesquisadora no atendimento diário do REMA, no período de dois anos, antes da coleta dos dados.

A pesquisadora era conhecida pelo grupo e, quando propôs trabalhar tal temática, esta foi comunicada às mulheres durante as sessões de grupo, que se encarregaram de conversar com os seus companheiros.

As mulheres que se interessaram pela pesquisa, conversaram particularmente com a pesquisadora para obter maiores informações sobre a pesquisa e, após, conversaram com os seus companheiros. Várias mulheres que me procuraram tinham dúvidas sobre as alterações que percebiam que estavam ocorrendo em seus corpos e relatavam que não haviam recebido nenhuma informação na área da sexualidade durante o tratamento, mas, ao consultarem os seus companheiros, eles não concordaram em participar da pesquisa, sendo então o 
casal descartado. No entanto, todas as mulheres que me procuraram, mas não quiseram fazer parte do estudo, ou por elas ou pelos companheiros receberam orientações nessa área.

Após os cônjuges terem aceitado participar do estudo, iniciamos as entrevistas, que foram todas pré-agendadas.

Nessa fase, utilizamos o gravador, o que permitiu o registro de dados com maior fidedignidade. O uso do gravador tem como desvantagem a impossibilidade de registrar expressões faciais, há o constrangimento do entrevistado em saber que está sendo gravado e a transcrição do gravador para o papel é trabalhosa, mas permite que o entrevistador consiga prestar mais atenção no que o entrevistado fala e o registro imediato das expressões verbais (LUDKE; ANDRE, 1986). Na fase das entrevistas, o caderno de notas foi utilizado como recurso para anotações complementares da mesma com o propósito de auxiliar na geração dos dados, cumprindo a etapa dos memorandos e diagramas.

As entrevistas dos cônjuges de um mesmo casal não foram realizadas no mesmo dia, visto que a metodologia proposta, a teoria fundamentada em dados, propõe que cada entrevista seja realizada, transcrita, analisada, porque, de uma, podem surgir novos dados que permitam serem aprofundados nas próximas entrevistas (STRAUSS; CORBIN, 1990).

Seguindo esse enfoque metodológico, os dados foram coletados no período de março a setembro de 2004. As entrevistas foram realizadas pela própria pesquisadora, assim como as transcrições. Para as entrevistas em que houve dificuldade de compreensão de sentido das respostas, retornamos aos informantes 
para esclarecer pontos dúbios e aprofundar temas, como no caso dos casais 1,2 e 5.

Aos casais 1 e 2, retornamos para aprofundar as entrevistas com os marido e, com o casal 5, foi realizada uma segunda entrevista com ambos; com o marido para aprofundamento e, com a mulher, porque houve perda parcial na fita da gravação. Esse segundo encontro mostrou-se extremamente frutífero, havendo uma complementação dos dados e trazendo outras questões que não haviam aparecido na primeira entrevista.

As entrevistas ocorreram sem transtornos porque, como havia sido previamente agendado, normalmente o entrevistado estava aguardando a minha chegada e se havia criado um ambiente no qual pudéssemos conversar sem interferência de telefone ou outras pessoas. Como as entrevistas com os cônjuges foram realizadas separadamente, fomos mais de uma vez a cada residência.

\subsection{Gerando os dados}

A organização dos dados foi realizada manualmente, tendo como base a Teoria Fundamentada em Dados, seguindo as etapas propostas por Strauss; Corbin (1990): 1) Coleta de dados empíricos; 2) Formação de conceitos; 3) Desenvolvimento dos conceitos; 4) Conceitos modificados e integrados e 5) Produção do relatório da pesquisa.

A Teoria Fundamentada em Dados é indubitavelmente derivada do estudo do fenômeno que representa, ou seja, ele é descoberto, desenvolvido e verificado 
provisoriamente a partir da coleta sistemática de dados e da análise permanente de dados daquele fenômeno. Portanto, dados coletados, análise e teoria mantêm uma relação recíproca.

Considerando que o referencial metodológico empregado propõe a comparação dos dados de uma entrevista com outra, a coleta e a análise dos mesmos se deram simultaneamente, ou seja, cada entrevista era realizada e analisada, o que permitiu a abordagem de novas questões nas entrevistas e o aprofundamento de temas que emergiram no momento.

Após a transcrição da entrevista, era realizada uma leitura minuciosa, visando identificar os códigos abertos por intermédio da seleção de trechos da entrevista, como se pode ver no Quadro 1.

Quadro 1 - CODIFICAÇÃO ABERTA

\begin{tabular}{|l|l|}
\hline Trecho da entrevista & Código aberto \\
\hline A gente acha que quando alguém & eu observo que é todo mundo quando alguém \\
mas eu observo que é todo mundo & em casa, quando a minha esposa ficou doente \\
quando alguém fica doente todo & todos ficaram também, todo mundo fica \\
mundo fica doente também. Eu & doente. \\
observei isso aqui em casa, quando & \\
a minha esposa ficou doente todos & \\
ficaram também, todo mundo fica & \\
doente.
\end{tabular}


Após a identificação dos códigos abertos de cada entrevista, buscou-se agrupar os códigos semelhantes em subcategorias e categorias, como mostra o Quadro 2. Esse processo metodológico permite juntar congruências ou incongruências de tal modo que ao terminá-lo, o pesquisador tenha o conhecimento das entrevistas no sentido do coletivo dos atores-sociais, ou seja, o agrupamento se dá de uma forma lenta, gradual e metodológica e permite, ao final, a criação dos quadros e diagramas.

Quadro 2 - FORMANDO CATEGORIAS E SUBCATEGORIAS

\begin{tabular}{|l|l|l|}
\hline Código aberto & Sub-Categoria & Categoria \\
\hline Em casa, quando a minha & Adoecer & Família \\
esposa ficou doente todos & & \\
ficaram também, todo & & \\
mundo fica doente. & & \\
\hline
\end{tabular}

Durante a análise dos dados, um número grande de categorias emergiram e, seguindo o enfoque metodológico proposto, foram reduzidas em número, de modo que o pesquisador pôde agrupá-las e concentrá-las em categorias com objetivos mais amplos (STREUBERT; CARPENTER, 1995).

A partir da sistematização das categorias e das subcategorias, foi possível montar os quadros com a codificação seletiva que permitiu uma categoria central e gerou os seguintes quadros: a mama e o câncer: um olhar, o exercício da sexualidade dos cônjuges que vivenciaram o câncer de mama casal. No entanto, ao iniciar a discussão dos dados, optamos por oferecer uma contextualização do câncer de mama, visando dar maior inteligibilidade aos dados (apêndice 4). 
Percurso metodológico

Os dados foram analisados e codificados por sexo, ou seja, os dados do gênero masculino e feminino foram comparados, tendo assim, uma visão distinta dos fatores que influenciam a vida sexual do casal.

Após a construção dos quadros que subsidiaram a discussão, realizamos o diagrama que permitiu visualizar os resultados com os fatores interligados. Nesse ponto, foi possível fazer a síntese do foco do estudo, tendo como referência as atitudes dos casais acerca da sua sexualidade e o processo de enfrentamento do câncer de mama que ocorreu entre eles. 
APRESENTAÇÃO E ANÁLISE DOS DADOS 


\section{4 - APRESENTAÇÃO E ANÁLISE DOS DADOS}

O método proposto nos levou a contextualizar o que é receber o diagnóstico de câncer e a criar dois diagramas: 1 - A mama após o câncer: um olhar e 2 - O exercício da sexualidade entre os cônjuges que vivenciaram o câncer de mama. É o que iremos discutir a seguir, para alcançarmos os objetivos.

\subsection{Contextualizando o diagnóstico do câncer de mama}

O câncer é o termo que damos a mais de cem doenças que tem em comum o crescimento desordenado das células. Esse crescimento pode ser em um órgão ou se espalhar por todo o corpo, o que chamamos de metástase. É uma doença que tem apresentado um aumento significativo nas taxas de ocorrência e prevalência, principalmente, nos países em desenvolvimento e que tende a aumentar nos próximos anos.

A Organização Panamericana de Saúde (OPAS, 2003, p. 39) relata que:

existem atualmente 20 milhões de pessoas que vivem com o câncer e que até o ano de 2020, esse será de 30 milhões. O impacto da doença é muito maior do que o número de casos sugere. O diagnóstico inicial é percebido pelos pacientes como uma ameaça à vida, e mais de um terço delas sofrem de ansiedade e de depressão. O câncer pode também ser prejudicial economicamente à família do paciente. 
Em nosso país o câncer ainda é tido como uma doença que mata, mas esse conceito vem mudando gradativamente, à medida de que a descoberta em estágios precoces, associada ao tratamento adequado, tem levado as mulheres a vivenciá-lo como uma doença crônica.

O câncer de mama inserido neste contexto vem sendo descoberto com maior prevalência e, hoje, é considerado a segunda causa de morte por neoplasias na mulher brasileira (BRASIL, 2004).

O hábito de examinar as próprias mamas não é muito freqüente em nossa população, mesmo com a existência de campanhas para o estímulo de tal prática há muitos anos. A não aderência a práticas saudáveis ou que ajudam a descoberta de sinais e sintomas de doenças tem sido muito estudada e parece estar relacionada à não percepção da suscetibilidade à doença, bem como à dificuldade de perceber a seriedade das mesmas. Em relação às praticas relacionadas ao diagnóstico precoce do câncer de mama, podemos citar o medo de encontrar um nódulo ou ter um diagnóstico de câncer.

Entretanto, é sabido que grande parte dos cânceres de mama são diagnosticados apenas após a percepção pelas mulheres de nódulos ou de sinais e, nesse estudo, essa ocorrência não foi diferente, mesmo entre as que referiram não ter o hábito de realizar o auto-exame. Esse fato levou-as a procurar assistência imediatamente.

"Eu achei um nódulo, mostrei para o meu marido e ele falou isso aí não é nada não. Eu falei: é lógico que é, é uma coisa diferente. Eu tenho que ir ao médico".(GF)

"Eu apalpei a mama e achei um carocinho aqui. Achei estranho, eu apalpei a outra mama e não achei nada e falei estou com um caroço no seio".GF)

"Passando a mão na mama, estava uma maior do que a outra"(M) 
O Instituto Nacional do Câncer (INCA) relata que os nódulos que são palpáveis podem indicar um câncer em um estágio mais avançado e que a mamografia de rotina após os 40 anos seria a conduta ideal para detectar estágios bem precoces da doença. Entretanto, $75 \%$ dos nódulos são encontrados pelas mulheres acidentalmente ou no auto-exame e, $23 \%$,no exame médico ou pelos companheiros (AYOUB et al., 2000). Este fato ocorreu neste grupo. Uma das mulheres referiu ter sido o médico que encontrou o nódulo e, posteriormente, teve o diagnóstico de câncer de mama.

"Eu nunca imaginava que ia ouvir aquele resultado que eu ouvi ali do médico àquela hora".(GF)

A procura do serviço médico neste grupo foi quase imediata, sendo que tivemos mulheres que demoraram alguns meses:

"Em março eu percebi um carocinho e em junho eu vi que tinha aumentado mais ainda, você palpava e pegava. Daí eu fui à ginecologista".(GF)

A demora para buscar um atendimento médico, no entanto, se deu por existir outras pessoas doentes na família e não pela falta de acesso aos serviços de saúde.

A mulher ao perceber alguma alteração na mamar tem retardado a busca dos serviços de saúde, e isso se deve ao medo de ter um diagnóstico de câncer, o que leva à descoberta do mesmo em estágios mais avançados, aumentando o índice de morbi-mortalidade (BRASIL, 2004).

Os companheiros afirmaram que vivenciaram o diagnóstico, inicialmente, com surpresa, porque era rotina da mulher a prática de exames periódicos preventivos e por conhecer os fatores que predispõem a doença e não se incluindo no grupo com maior predisposição à manifestação do câncer.

"Eu fiquei admirado porque fazia 3 a 4 meses que ela fez exames".(GM) 
"Para nós foi uma surpresa, ela estava fora das estatísticas, não há casos na família". (GM)

O câncer é uma doença que se manifesta silenciosamente e, por estar associada a fatores ambientais e pessoais, sua ocorrência não se restringe aos grupos de risco. A Organização Mundial de Saúde (OMS) considera como fatores determinantes para o desenvolvimento do câncer o aumento da expectativa de vida, a urbanização, a industrialização e os hábitos de vida, justificando a importância de diminuir e de controlar os fatores a que a população está exposta e que podem facilitar o seu aparecimento (BRENTANI; COELHO; KOWALSKI, 2003).

Receber um diagnóstico de câncer, doença estigmatizada e associada à morte, levou à emergência de sentimentos diferentes entre as mulheres e seus companheiros. As mulheres foram mais positivas em relação ao enfrentamento da doença que seus companheiros, mesmo entendendo que o câncer de mama poderia levar a uma mutilação, a um tratamento prolongado e, em determinadas situações, desfigurante.

A preocupação e a tristeza contrastaram com a esperança que as impulsionaram para a tomada de decisão em relação ao seu tratamento.

"Eu achei que eu ia morrer naqueles dias. Daí eu chorei. Mas eu vi que nem sempre as pessoas morrem de câncer e comecei a ver que não é só câncer que mata".(GF)

O sentimento de finitude surge com o diagnóstico de câncer, mas a vontade de querer ficar bem levou essa mulher a ver que outras patologias também podem levar à morte.

O diagnóstico do câncer de mama despertou sentimento de perda e de sofrimento, que são expressos com muita intensidade nas emoções.

"É como se tivesse sumido o chão. Como se batesse um fusca com um FNM e o fusca era eu". (GF) 
O diagnóstico do câncer parece, também, ter dado às mulheres a dimensão de finitude.

\begin{abstract}
"Nascemos com uma data de validade. Quando se tem uma notícia de que você tem um câncer ou uma doença grave significa que o seu tempo de validade será menor".(GF)
\end{abstract}

Esses dados corroboram outros estudos, como Rossi; Santos (2003) que relatam que as mulheres ao receberam o diagnóstico de câncer de mama passam a ter consciência da possibilidade da morte iminente, além de sentimentos como tristeza e angústia.

Observamos que as emoções dos companheiros relacionadas ao diagnóstico do câncer foram tão intensas quanto às delas e revelam expressões de desesperança, ao contrário das esposas:

"Fiquei angustiado. Foi como uma paulada na cabeça. Eu pensei que ela ia morrer. Eu fiquei cismado de acontecer alguma coisa" (GM)

"Eu não aceitava, a minha reação foi de desespero. Foi desespero e revolta. Coitada da minha mulher, coitada!, coitada!".(GM)

"Eu me senti muito fraco, por eu não poder fazer nada". (GM)

Os sentimentos masculinos estiveram ligados a reações internas como fraqueza, angústia, desespero, tidas como aspectos femininos em nossa cultura. A sensação de impotência perante o diagnóstico de nada poder se fazer é um sentimento que gera a angústia, pois o homem culturalmente é prático e solucionador de problemas.

Dados semelhantes encontram-se no estudo de Cerqueira (2004, p. 77) que relata que o "esposo se sentiu impotente, intranqüilo, que teve medo dela morrer, mas que tentou pensar positivamente". Fernandes (1997, p. 80) relata em seu estudo que os maridos tiveram comportamentos diferentes, que "variaram da aceitação do fato, procurando manter a aparência de normalidade, à omissão, 
negação do acontecimento expressa pela recusa em não ver a área cirurgiada, até o desaparecimento e o abandono da casa".

Entre os homens estudados, o impacto do diagnóstico foi relatado como algo que superou a perda da mama porque representou, para eles, a possibilidade da perda de suas companheiras.

"A notícia do câncer foi muito mais forte do que perder a mama". (GM)

Acreditamos que a desinformação e o estigma cultural existentes sobre o câncer tenham desencadeado esses sentimentos. No Brasil, o câncer é uma doença cujo prognóstico é quase sempre duvidoso e está associado a multifatores relacionados à gênese da doença e comprometidos pela dificuldade de acesso aos serviços de saúde, bem como à carência de implantação de programas de detecção precoce.

"Ele (o câncer) é muito tenebroso, ele é mais violento, e é pior do que a AIDS. Tem que ser respeitado. Porque essa doença, de cem pessoas dez vão se salvar, as outras não se salvam e durante o tratamento é muito sofrimento, tenha misericórdia, a pessoa sofre demais".(GM)

Perceber o câncer como uma doença sem controle e associá-la à Síndrome da Imunodeficiência Humana Adquirida (SIDA) também é relatado no estudo de Almeida et al. (2001) com mulheres que também fazem a comparação com essa patologia, entendendo que para essa doença é possível a prevenção e o controle, enquanto que, para o câncer, a possibilidade de prevenção e de controle não é tão fácil.

Apesar dessa percepção de que o câncer poderia levar à finitude da vida, o enfrentamento da doença e do tratamento se fez presente no sentido de que "já que o problema existe, vamos resolver logo" ${ }^{1}$.

\footnotetext{
${ }^{1}$ Dito Popular.
} 
"Eu não senti raiva, eu não senti medo, eu não fiquei desesperada, eu não fiquei revoltada, eu fiquei preocupada e queria resolver tudo da noite para o dia".(GF)

É comum, quando se tem um problema, querer sua resolução rapidamente, principalmente quando este está relacionado com a saúde e é considerado grave, como o câncer.

Dado esse semelhante ao estudo de Bergamasso (1999, p. 90) que relata que "a mulher querendo se livrar da doença age de forma rápida, não perdendo tempo, desejando resolver da forma eficaz aquilo que não pode evitar".

Sabemos que o tratamento do câncer de mama é prolongado. A cirurgia leva a mulher a ficar com o dreno a vácuo que será retirado após 10 a 15 dias. Se não foi submetida à quimioterapia pré-operatória, esta poderá ocorrer no pós-operatório, assim como a radioterapia ou ambas. Esse período pode variar de dois a sete meses e, quando a mulher trabalha fora de casa, deverá ficar afastada, nesse período, dependendo do tipo de trabalho que ela executa.

Neste grupo estudado, nem todas as mulheres trabalhavam fora de casa, mas todas fizeram alterações em sua rotina de trabalho, seja esse fora ou dentro do domicílio, seja de alguns dias ou de afastamento total.

"Eu não sei o que vai acontecer daqui para frente, eu não sei se volto a trabalhar, se eu vou ficar em casa, mas eu vou ter que fazer o tratamento. Eu vou pensar primeiro em mim e depois no serviço e é isso o que eu estou fazendo".(GF)

A consciência de querer ficar curada e continuar a vida se fez presente. Pessoas com diagnóstico de câncer e que valorizam o viver tendem a ter o comportamento de seguir o tratamento corretamente e começá-lo o mais rápido possível, porque têm ânsia de ficarem boas logo e continuarem a sua rotina de vida. A doença é tida como um momento, uma fase e não um fim e, por isso, não há a necessidade de se afastar definitivamente das atividades diárias nem se aposentar. 
Remen (1993) relata que, para algumas pessoas, o viver é mais importante. Para elas, a saúde é um recurso humano, uma capacidade que lhes permite expressar suas prioridades e senso de objetivo e viver de acordo com os seus valores é um modo de se manter vivo.

Aceitar a doença e procurar manter a mente ocupada e com planos futuros foi importante e as mulheres colocaram-se diante da doença de forma positiva como observamos no relato:

"Eu não me apavorei; eu estava com problemas maiores. Foi bom para mim, me aliviou do outro lado. Se eu não tivesse tido um câncer eu teria tido um enfarte".(GF)

Para essa mulher, a doença foi um fato decisivo que marcou o antes e o depois do câncer no sentido de dar uma parada na vida, e que conseqüentemente essa parada Ihe serviu para reflexão e para melhorá-la como um todo e não apenas cuidar da doença. O período de doença foi uma oportunidade para esclarecer o que para ela estava inconsciente e a levou a modificar-se, replanejando sua vida.

Sabemos que o estresse é um dos problemas de saúde que afeta as pessoas no mundo todo. O estresse prejudica o funcionamento do sistema imunitário permitindo uma fragilidade do mesmo e deixando o corpo mais exposto às doenças sistêmicas, psicológicas e o câncer. Quando uma pessoa tem um câncer, além do tratamento do mesmo, é recomendada a mudança de hábitos de vida de modo, sendo que, terminado o tratamento, a pessoa não se submeta aos mesmos fatores que poderiam ser o desencadeante da patologia (LEITE; OLIVEIRA; RIBEIRO, 2002).

Os avanços tecnológicos para o tratamento do câncer e a veiculação, na mídia, de pessoas famosas que tiveram câncer, que se trataram e se expõem 
falando de como descobriram a doença, o tipo de tratamento a que se submeteram e que voltam à ativa reassumindo seu trabalho vêm contribuindo para desmitificar a doença (VALLADARES; BÉRGAMO, 2005).

Outro elo de grande importância, quando ocorre um diagnóstico de câncer de mama, é como a família irá se interagir perante o problema.

A família é tida como um elo entre várias pessoas que podem morar ou não no mesmo espaço. Quando um desses membros adoece, pode afetar a saúde familiar. Elsen (1994, p. 69) relata que "quando um dos membros da família adoece os papéis precisam ser redimensionados e o estresse permeia as relações interpessoais, gerando, inclusive uma situação de crise na unidade familiar".

O diagnóstico do câncer de mama leva a família a expressar sentimentos diferentes e, em alguns casos, a se reorganizarem de uma nova forma.

A dúvida em dar ciência aos filhos acerca do câncer, da cirurgia e das reações adversas aos medicamentos durante a quimioterapia esteve presente no casal. No entanto, a reação por parte dos mesmos foi diferenciada prevalecendo sentimentos de preocupação e tristeza, mas impulsionando-os a comportamentos afetivos que foram expressos pelas mulheres como positivos para o enfrentamento da doença.

"Tanto ele (o marido) como os filhos ficavam muito chateados. Tanto que aumentou o meu dengo, ficaram preocupados, com mais carinho, com mais atenção". (GF)

"A minha família toda ficou muito preocupada". (GF)

"O meu marido contou para a mais velha (filha) e quando fiz a cirurgia ela chorou muito".(GF)

"Eles (os filhos) ficavam muito ruinzinhos, quando me viam vomitando durante a quimioterapia. Tinha um clima de chateação".(GF) 
A família esteve mais presente na fala do gênero feminino do que no masculino, sendo que estes tiveram mais dificuldades ao lidarem com a doença e mostraram mais suas incertezas, negando-a ou preocupando-se com o futuro dos filhos.

"Eu procuro falar o menos possível. Fica todo mundo no pé, até os meninos".(GM)

“No início eu não contei para ninguém".(GM)

"A minha filha já está ficando mocinha. Tinha hora que ela não se agüentava. Comentava comigo, será que quando eu ficar adulta eu vou ter isso, também"?(GM)

"Todo mundo ficou doente. A família interagiu, ficou mais unida e conversa mais".(GM)

Pitceanthly; Maguire (2003) relatam que o ajuste das pessoas que cuidam do paciente com câncer está relacionado com a sua expectativa em relação à doença. Os que são mais otimistas são menos depressivos e mais bem ajustados psicologicamente. As pessoas que vêm o câncer negativamente consideram o tratamento estressante, sentem-se mais incertas ou desesperadas e são mais propensas a serem ansiosas ou a apresentarem depressão.

Dousset (1999, p. 184) relata que "a doença modifica a imagem que a criança tem de seus pais porque descobre que eles são mortais. Por outro lado ela pensa em sua sobrevivência e fica insegura sobre como será o seu futuro", por isso é importante contar a ela o que está acontecendo e reafirmar o amor que se tem por ela e as expectativas para o futuro.

Biffi (2003) relata em seu estudo que toda a família sofre alterações e se reorganizam para superarem juntos o diagnóstico do câncer de mama de um de seus membros. 
Os dados do presente estudo revelam que o impacto do diagnóstico foi superado e com o passar do tempo as famílias foram se reorganizando, inclusive na distribuição do serviço doméstico, visto que havia necessidade de as mulheres evitarem o esforço para prevenir o linfedema. Essa reorganização, segundo os participantes do estudo, ocorreu de um modo peculiar, mas sempre buscando um equilíbrio. Alguns membros das famílias passaram a ajudar nas tarefas domésticas ou buscaram o auxílio de outros.

A preocupação com o linfedema, uma das complicações mais temidas do tratamento do câncer de mama apareceu, como um divisor na reorganização do serviço doméstico. O linfedema pode ocorrer desde o pós-operatório imediato como após alguns anos e normalmente ocorre após uma lesão do membro superior do lado operado (CAMARGO; MARX, 2000). É uma das complicações mais comuns no pós-operatório do câncer de mama e que gera um incomodo físico e emocional nas mulheres (PANOBIANCO; MAMEDE, 2002). Assim, um dos cuidados, após a cirurgia de câncer de mama com retirada da rede de linfonodos axilar, é a prevenção de acidentes com o braço no sentido de prevenir o linfedema.

"Ela não pode abusar, por exemplo ela não pode ficar pegando panelas, coisas quentes. Se ficar pegando o braço pode inchar, então se for fazer exercício, tomar cuidado com o peso e tomar cuidado com os remédios, o médico explicou o que podia e o que não podia. Para começar ela tem 4 filhos, esse homens dão um trabalho danado, tem que lavar roupa, limpa a casa embora que depois que ela operou e aumentou a casa vem uma moça para dar uma geral porque senão ela não ia agüentar mesmo".(GM)

"Porque hoje lá em casa quem passa a roupa sou eu". (GM)

"Ela ficava sentadinha aqui e eu fazia o almoço e o jantar".(GM)

"Se ela vai fazer um assado, ela tempera e eu coloco no forno. Vai passar um pano na casa, sou eu que torço. Arrumei uma pessoa para limpar a casa. Eu não deixo ela andar de ônibus, eu levo e busco".(GM) 
Em nosso país os afazeres domésticos são tarefas tidas como do gênero feminino e mesmos as mulheres que trabalham fora de casa, normalmente desempenham essa dupla jornada ou delegam a outra mulher. Nesse grupo de estudo, os homens assumiram algumas tarefas domésticas tidas como femininas, como o passar a roupa. No entanto, observamos que o administrar a casa e muitas outras tarefas domésticas continuaram com a mulher ou foram delegadas a outra, especialmente os afazeres que os homens consideraram que podiam ser prejudiciais as suas companheiras, como lavar e passar roupa, fazer faxina.

A sociedade está estruturada em dois gêneros, e para cada um, determina o que é mais esperado dele, mas em determinadas situações, como no caso de doenças, esses papéis podem ser assumidos pelo outro.

Neste estudo, observamos que os homens passaram a realizar algumas atividades domésticas, mas pontualmente e sem intenção de assumir integralmente o trabalho feminino, visto que nenhum dos homens assumiu todas as tarefas domésticas e, sim, aquelas de que gostavam ou se sentiam mais aptos a realizar.

Holmberg et al. (2001) relatam que os companheiros, após um câncer de mama, assumiram algumas atividades domésticas como limpar, cozinhar e manter a ordem da casa, mas devemos compreender que esse trabalho foi realizado nos Estados Unidos da América, sociedade onde o empregado doméstico é mão-de-obra cara.

No Brasil, $80 \%$ do trabalho doméstico é realizado por mulheres, independentemente do fato de trabalharem fora ou não. Os homens participam do trabalho doméstico comprando comida, ajudando a lavar os pratos e cuidando das crianças (RIBEIRO, 2005). 
Apresentação e análise dos dados

Alguns companheiros mudaram de emprego, bem como passaram a flexibilizar sua rotina de trabalho de tal forma que estivessem sempre disponíveis para as necessidades das esposas e pudessem dar maior assistência a elas.

"Depois eu dei um jeito de parar de viajar, mudei o meu trabalho, comecei a trabalhar só na cidade para poder ficar em casa, não ficar fora".(GM)

"Chamei o meu patrão, o meu chefe do departamento pessoal, contei toda a história para eles e eles me deram todo o apoio. Se você precisar sair, nem precisa avisar, vai fazer e acabou e o que você precisar, nós estamos aqui".(GM)

A preocupação dos homens não foi ter com quem conversar, nem desabafar sobre o que estava acontecendo e, sim, criar condições para terem maior liberdade de se ausentarem do serviço, com maior flexibilidade para buscarem suas companheiras durante o tratamento.

Biffi (2003) relata que a dinâmica familiar estará modificada, quando se tem um diagnóstico de câncer de mama de um de seus membros e que as filhas têm uma preocupação maior com os cuidados e afazeres domésticos, do que os filhos e os maridos.

Observamos que, neste grupo estudado, os homens fizeram o movimento de se fazerem presentes, principalmente em estarem à disposição da companheira para esta realizar o tratamento do câncer de mama e, em menor número, se responsabilizaram pelas atividades domésticas. 


\subsection{A mama após o câncer: um olhar}

A mama é um órgão duplo situado na parte anterior do tórax e que sofre alterações durante quase toda a vida da mulher. É um símbolo de feminilidade da mulher e mesmo estando longe dos órgãos genitais, tem uma relação direta com esses, devido as alterações dos hormônios sexuais e por ser sensível ao toque e participar das atividades sexuais como um órgão erótico.

Diagrama 1 - A MAMA APÓS O CÂNCER: um olhar

A MAMA E O CÂNCER

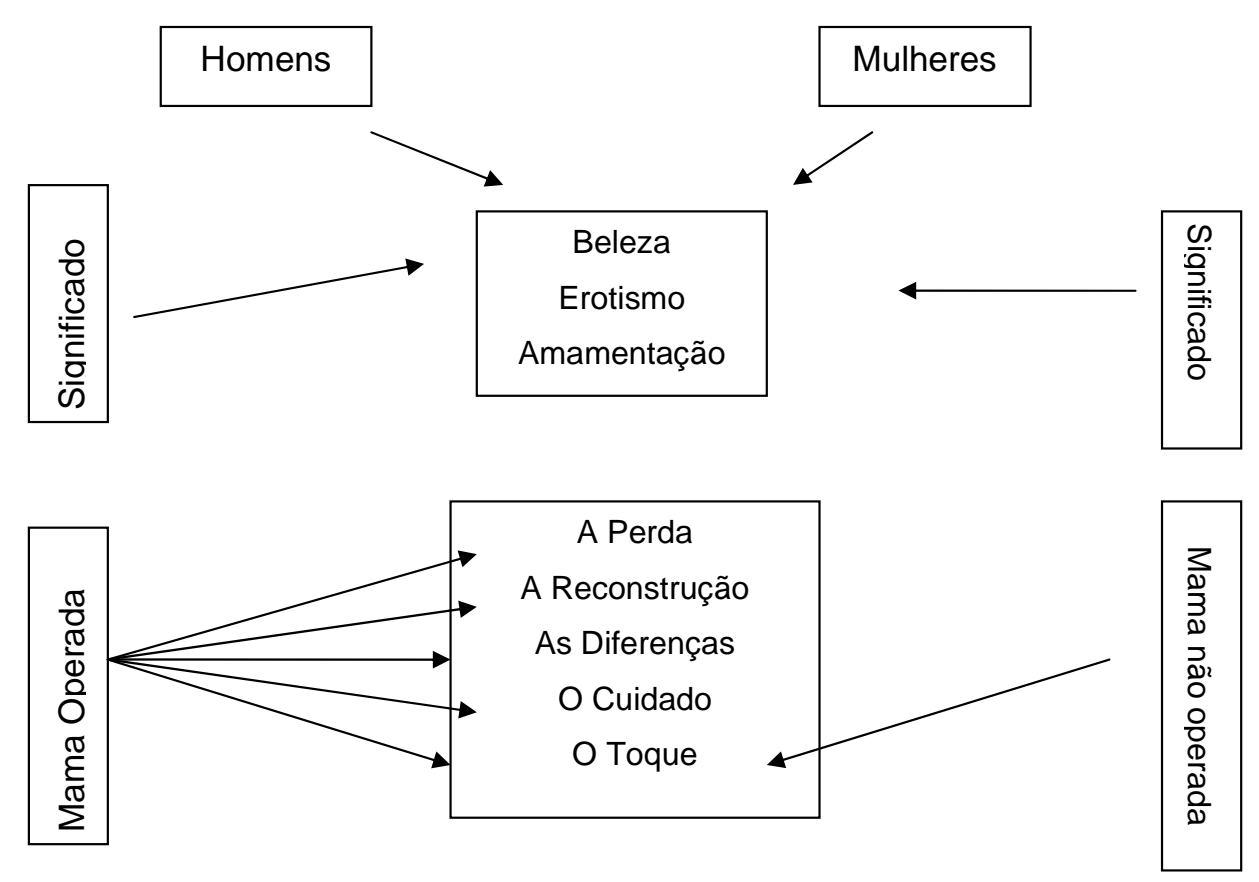


O diagrama 1 refere como a mama é vista após o câncer, quais sentimentos, como ela é percebida após a doença, e o retorno às atividades sexuais.

\subsubsection{A beleza da mama}

A mama é vista sob olhares diferentes nas várias etapas da vida da mulher e, enquanto para os profissionais de saúde, ela é vista sob o olhar de sua funcionalidade fisiológica ou patológica. Culturalmente, ela é reconhecida por ser símbolo de beleza ou de erotização.

Yalon (1997, p. 325) relata que as mamas têm um lugar privilegiado na imaginação humana e que as pessoas as vêem conforme a sua realidade. Assim:

[...] os bebês a vêem como fonte de alimento. Os homens vêem sexo. Os médicos vêem doença. Os homens de negócios dólares. As autoridades religiosas transformaram os seios em símbolos espirituais, ao passo que os políticos apropriam-se deles por motivos nacionalistas. A psicanálise coloca-os no centro do inconsciente, como se fossem monolitos imutáveis.

No mundo atual, o corpo passa a ter uma conotação que envolve não somente o cuidado para mantê-lo saudável, mas ele deve ser bonito, ter formas bem definidas e esculpidas para ter uma boa apresentação. Esses conceitos são incutidos pela sociedade, principalmente por meio da propaganda, em que as mamas são tratadas como um produto de comércio e, o modo de conservá-la com uma aparência jovial, é estimulado freqüentemente pela mídia (YALON, 1997).

Em nosso grupo de estudo, as mamas foram apontadas com significados culturalmente definidos e são apresentadas como órgão feminino belo e que atrai o macho, importante na estética e na relação sexual. As mulheres, talvez por terem a 
imagem da mama alterada, deram mais ênfase a elas em seus discursos do que os homens:

"A mama lhe deixa mais mulher, mais vaidosa, quando você coloca um sutiã, uma roupinha que mostra mais". (GF)

"Eu gosto de mulher com seios bonitos".(GF)

As mulheres referiram a mama bela, com estética, mas não relataram as mudanças que ela sofre com o envelhecer. Isso nos leva a pensar que, no imaginário feminino, a mama é sempre jovem, não sofre as alterações da idade e, quando temos um câncer de mama, ela passa a ter um significado forte de modificar a feminilidade.

Entre os homens, a beleza foi evidenciada, apontada como importante para a imagem da mulher e como referência de feminilidade.

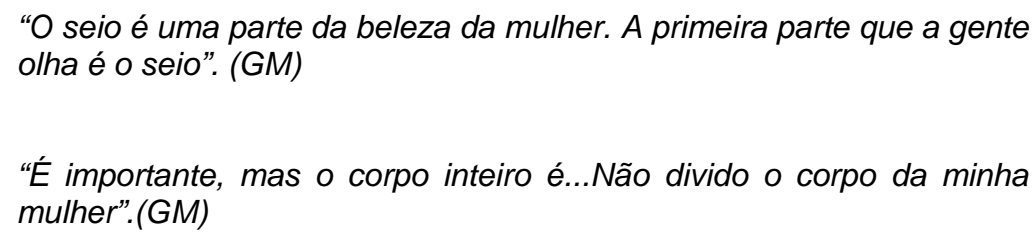

A compreensão de que o corpo não deve ser dividido em pedaços é uma abordagem que facilita a aceitação de que um pedaço do corpo se foi, mas o todo continua. Talvez esse seja um mecanismo de defesa para aceitar melhor a mastectomia.

Nos homens surgiram sentimentos negativos sobre a mulher sem mama.

"Uma mulher sem mama é horrível. Mulher sem mama é esquisito" (GM)

A dificuldade de se ter ou se ver um corpo mutilado pode trazer sentimentos que terão que ser trabalhados introspectivamente para aceitar a situação e, quando 
ela ocorre em um órgão de identificação feminina, leva o homem a necessidade de reconstruir o conceito sobre esse novo corpo.

\subsubsection{A mama como órgão erótico}

A mama, mesmo se situando longe dos órgãos genitais está diretamente relacionada a eles, pois sob influência da ação de hormônios sexuais ela se torna uma área erógena, estimulada durante a relação sexual.

O início do ato sexual, na maioria das vezes, começa com as carícias preliminares entre os parceiros, que se concentram nas zonas erógenas. Essas são regiões do corpo que, ao serem estimuladas, levam à lubrificação dos genitais, preparando-os para o ato sexual. Apesar de sabermos que os lábios, a pele, os genitais, as mamas, o pescoço são regiões erógenas, a resposta ao estímulo dessas regiões faz parte do processo de descobertas de cada casal.

Costa (2004, p. 45) relata que "as mamas e os mamilos são zonas erógenas fundamentais, sendo que algumas mulheres podem atingir o orgasmo apenas com a estimulação dos mamilos". Argumenta ainda que, apesar da ênfase dada à beleza da mama, a sensualidade da mulher é mais importante do que sua estética.

Entretanto, os homens apesar de relatarem sobre a beleza da mama, não a colocaram como parte integrante do relacionamento sexual, mas as mulheres demonstraram que ela é um órgão prazeroso dentro do ato sexual.

Assim, mesmo considerando as alterações fisiológicas que ocorrem ao longo da vida da mulher, a mama mantém a sensibilidade nervosa que estimula sexualmente tornando o toque agradável e excitante.

"Nossa! A mama é tudo, ela é uma beleza, a mama na hora do sexo..." (GF). 
"A mama na relação sexual é um órgão importante". (GF)

"A mama é assim uma parte estética e a gente que tem marido se sente mais mulher".(GF)

As mulheres colocam o prazer que sentem nas mamas durante um relacionamento sexual, quando estas são estimuladas, fato que os homens não relataram apesar de, em outros momentos, mostrarem que a ausência dela não é agradável.

\subsubsection{A mama e a amamentação}

A mama como órgão responsável pela alimentação do bebê é conhecida desde o início da humanidade. Embora a humanidade tenha passado por fases em que as mulheres da alta sociedade não eram estimuladas a amamentar devido à necessidade de acompanhar seus maridos na corte, quando entregavam seus filhos as amas de leite, nos últimos dois séculos o aleitamento materno foi estimulado e colocado como um papel feminino (BADINTER, 1985).

O estímulo ao aleitamento materno tem sido uma política pública e busca incentivar a mulher a manter o aleitamento exclusivo até o sexto mês de vida da criança quando possível, prolonga-lo até os 2 anos do infante. $\mathrm{O}$ ato de amamentar é estimulado pela sociedade e, fazê-lo em público, não é tido como agressão e nem falta de pudor (MARTINS FILHO, 2001).

No grupo estudado o amamentar foi lembrado por um casal:

"Eu gostava demais de amamentar".(GF)

"Eu a vi amamentando meus dois filhos, até o filho de uma senhora que não tinha leite" (GM) 
Esse casal relembrou com saudades esse ato, colocando-o como um fato prazeroso, trazendo satisfação para a mulher e admiração ao homem, o que nos reporta ao fato de que o órgão tem sido culturalmente valorizado e reconhecido como importante para a manutenção da vida.

Este registro, entretanto, em um contexto de incerteza nos aponta para o significado que a perda da mama ou parte dela representa para os casais pesquisados.

\subsubsection{A mama operada}

Ao se ter um diagnóstico de câncer de mama, além da insegurança de ter um câncer, a mulher terá que se submeter a um tratamento considerado agressivo, visto que ele corta, envenena e queima, o que corresponde à cirurgia, à quimioterapia e à radioterapia. Conviver com a expectativa do que pode acontecer é uma reação constante encontrada nestas mulheres (LAMBERT, 1996).

Apesar da retirada da mama ser muitas vezes a prática para erradicar o câncer, hoje, devido ao avanço tecnológico e à detecção precoce de estágios iniciais do mesmo, são possíveis cirurgias menos mutilantes ou há a reconstrução da mama no momento da mastectomia (MENKE et al., 2000).

\subsubsection{A Perda}

As reações de submeter-se a uma mastectomia não foram iguais entre as mulheres, apesar de haver algumas semelhanças. Acreditamos que esse fato se deu devido ao procedimento cirúrgico que não foi o mesmo entre elas. 
Vários estudos relatam que a perda da mama é difícil para as mulheres porque afeta diretamente a sua auto-imagem (ALMEIDA, 1997; ROSSI; SANTOS, 2003, SILVA; MAMEDE, 1998).

"Quando cheguei do hospital e me vi sem a mama, eu chorei bastante. No início foi meio difícil olhar no espelho sem a mama". (GF)

A mama na mulher é um símbolo de feminilidade, de beleza, de eroticidade e de identificação do sexo e, dependendo de como ela é percebida e sentida, gerará o grau de importância que as pessoas lhe darão, levando a um sofrimento maior ou menor. O sentimento de perda pode ser percebido pela fala abaixo:

"Foi uma parte dela que se perdeu" (GM)

Entretanto, a aceitação do inevitável acaba ocorrendo e a mulher passa a conviver com a perda, ressaltando os aspectos saudáveis do viver.

"Só vejo que eu estou sem a mama na hora que eu tiro a roupa e me olho no espelho e vou tomar banho, mas fora isso não aparece".(GF)

Entre as mulheres em que a cirurgia resultou, apenas, na retirada de nódulo ou de um quadrante, verificamos que suas falas dirigiam mais para as preocupações com o câncer e com a estética do que propriamente com a perda. Uma das mulheres identifica que, após a cirurgia, a estética da mama operada ficou melhor que a outra, dado esse que mostra que as técnicas cirúrgicas têm avançado e isso contribui para a diminuição de mamas desfiguradas.

"O seio operado ficou melhor do que o outro. Ele retirou o bico e mexeu e organizou a mama e costurou o bico de novo".(GF)

Neste mesmo grupo, uma das mulheres relata que a retirada da mama, também poderia ser superada mediante os avanços nas técnicas cirúrgicas de reconstrução.

"A mama não é importante, depois você pode por uma prótese, fazer uma reconstrução." (GF) 
Para essa mulher, a superação do câncer é mais importante, mas o desconhecimento do significado de ter uma mama extirpada e das complicações que isso pode acarretar, não faz parte do seu imaginário. Ela coloca de uma forma simplista a utilização de uma prótese, a substituição da mama retirada, parecendo não ter a noção dos problemas psicológicos e físicos que isso pode acarretar como a baixa da auto-estima, da auto-imagem, as alterações posturais, entre outros.

\subsubsection{A Reconstrução}

Com o avanço das técnicas cirúrgicas e estudos de sobrevida com tratamentos conservadores na cirurgia para o câncer de mama, sempre que possível, excluí as indicações radicais com a excisão da mesma juntamente com os músculos do pequeno e grande peitoral. Isso possibilitou incisões menos invasivas e permitiu a inclusão da cirurgia plástica, dependendo do estadiamento do câncer e da condição de saúde geral da mulher.

A técnica a ser utilizada na reconstrução da mama varia conforme a condição física da mulher e a indicação do cirurgião, podendo ser realizada, utilizando-se o tecido disponível e um implante, expansores teciduais e retalhos. O que vai determinar a escolha da cirurgia é a quantidade de tecido que sobra após a retirada da mama (DONAHOE, 1997).

Não temos dúvidas de que a reconstrução tem um aspecto benéfico na dimensão do psicológico e físico da mulher, pois não há uma alteração visual do volume mamário. No entanto, sabemos que esse tecido não é mamário e, por isso, a 
mulher não terá as mesmas sensações anteriores, o que muitas vezes pode ser decepcionante para a mulher.

Smeltzer; Bare (2002) relatam que, nos Estados Unidos, 75\% das mulheres com câncer de mama que se submeteram à mastectomia elegeram a reconstrução mamária no momento da cirurgia. Essa, entretanto, não é a realidade brasileira, em que a maioria das mulheres ainda não têm acesso a esse benefício, mesmo sendo hoje garantida a reconstrução mamária financiada pelo SUS. Em nosso estudo, as mulheres referem que o médico discutiu a reconstrução frente a necessidade da mastectomia como um fator positivo para a sua tomada de decisão.

"O médico falou hoje em dia não tem necessidade de ficar mutilada, hoje você tem opções de sair da mesa de cirurgia sem essa sensação de perda". (GF)

Ao se optar pela reconstrução, é importante o casal ser esclarecido que a mesma não interfere no tratamento do câncer, mas que embora tenha um bom resultado estético, a mama reconstruída nunca será como outrora. Do ponto de vista psicológico, sair da cirurgia com uma nova mama é mais animador do que perceber a mutilação e este foi um dos fatores que levou os casais a optarem pela reconstrução.

"O médico me deu duas alternativas: ou eu tirava tudo e fazia a reconstrução ou ficaria com a minha mama, faria a quimioterapia e a radioterapia e voltava daqui a 5 anos ou antes. Eu optei por retirar a mama e a reconstrução por silicone veio do meu marido, porque quando o médico falou de abrir o músculo, cortar a barriga, ele fez um escândalo. Eu me sinto bem com a mama reconstruída".(GF)

"O médico falou: vamos ter que partir para a mastectomia e pediu para fazer a avaliação para fazer a reconstrução. Fazer a reconstrução foi reconfortante, é aquela coisa de você não se sentir mutilada, alguma coisa Ihe faltando".(GF)

"A reconstrução é melhor, é benéfica. O impacto é maior".(GM)

“Quando ela acordou, ela já estava com o seio".(GM) 
O casal, ao optar pela reconstrução, deve ser esclarecido que esse é um processo de três estágios: o primeiro é a criação da protuberância mamária, o segundo é a obtenção da simetria com a mama co-lateral e, o terceiro, é a criação do complexo aréolo-mamilar (SMELTZER, BARE, 2002). A compreensão dessas etapas é de extrema importância para a aceitação dessa nova mama e para não deixar a mulher ou o companheiro decepcionados com o resultado iminente. Percebemos que no grupo de estudo o conhecimento desses estágios não ficou claro para o casal, pois a decepção foi vivida por alguns.

"Quando retirou o tampão, eu chorei muito: meu Deus quanta marca! Mas deve valer a pena!" (GF)

"Ninguém me falou como era essa nova mama, a sensibilidade não existe e eu sinto um frio tremendo".(GF)

Donahoe (1997, p. 896) relata que, após a cirurgia de reconstrução mamária, "a mama não será a mesma que no estado pré-operatório. A mama será mais semelhante a um monte e será mais simétrica possível em relação ao lado contralateral". Por isso a importância da orientação dos profissionais de saúde ao casal que opta pela reconstrução no momento da mastectomia, porque a mulher espera um resultado mais positivo no sentido fisiológico, enquanto que o profissional pensa na estética.

Mesmo tendo algumas dificuldades sobre a aceitação dessa nova mama, a mulher apresenta uma nova situação por ela vivenciada, que a conforta por ter tido a opção da reconstrução.

"Eu nunca tinha visto ninguém sem mama e quando uma pessoa me mostrou e vi que não posso me queixar da reconstrução".(GF)

Observamos que a situação da mutilação não havia sido vivenciada por essa mulher e que, após vivenciá-la, a aceitação da reconstrução se torna mais amena. 
Mas a reação diante da reconstrução não foi igual para as mulheres que se submeteram a ela, visto que as técnicas cirúrgicas foram diferentes e que cada pessoa reage de um modo à mesma situação. Uma das mulheres nos relata uma relação positiva com essa nova mama:

"A mama reconstruída, ainda falta fazer o mamilo, mas não estou muito inclinada a fazer não. Não me faz falta. Porque no dia a dia, a mama não incomoda, não atrapalha em nada e eu já coloco blusinha de alça, tomara que caia e saio numa boa". (GF)

Para os homens, o aspecto variou de aceitação imediata a aprender conhecer essa nova mama.

"Para mim é um seio normal". (GM)

"Essa mama é uma situação nova, mas existe um tabu meu, um bloqueio que vou quebrando devagar". (GM)

Lambert (1996, p. 211) nos conta que, após a reconstrução da mama, "é necessário um tempo para conhecer esse novo corpo, para incorporar essa peça nova e estranha ao velho e familiar conjunto". Se a mulher tiver que aprender a conhecer essa nova mama, com sensações diferentes do que a existente, isso também ocorrerá com o seu companheiro. E, como a aceitação do novo é diferente para as pessoas, obrigatoriamente ela não ocorrerá ao mesmo tempo no casal.

Essa percepção da existência de algo novo é evidente, TAMBÉM para esse companheiro:

"A gente sabe que não é dela. Ela também sabe que é uma coisa que não é dela".(GM)

Apesar de ter que se conhecer essa nova mama, sabemos que a imagem física da mulher submetida à mastectomia com reconstrução é melhor do que aquela que não a fez. No entanto, para algumas mulheres, o resultado pode ser inesperado 
e traumático, sendo que o tempo para aceitar essa nova imagem é superior a um ano (HARCOURT; RUNSEY, 2001).

\subsubsection{Percebendo as diferenças e tendo cuidado}

A cirurgia, independentemente do tipo, levou as mulheres a tomarem cuidados diferentes com a mama e com o local operado. A dor e a sensibilidade alterada na região da cirurgia foram as queixas mais comuns e que as levaram a evitar o toque.

"Apesar de que a minha mama ficou muito dolorida". (GF).

“Tem que ter cuidado, ela está cicatrizada, mas ela sente".(GM)

A mama é um órgão extremamente vascularizado e inervado e, quando a mulher é submetida a qualquer tipo de cirurgia, a inervação é seccionada e o local pode ficar sensível por algum tempo, dependendo da extensão da lesão e das aderências que podem ocorrer, o que influenciará na sensibilidade à dor.

Quando falamos de dor, sempre pensamos no local cortado, mas também existe a dor de natureza emocional decorrente da perda do órgão, e que pode ser expressa de forma subliminar, por meio da descrição de sensações desagradáveis que a retirada da mama suscita, como aparece evidenciado na fala de um dos companheiros:

"Você vê aquela situação, a mulher mutilada". (GM)

A perda de qualquer parte do corpo é significativa e tende a desencadear no outro sentimentos ambivalentes de rejeição e de piedade, o que vários trabalhos sobre mulheres mastectomizadas demonstram (CLAPIS, 1996; SILVA; MAMEDE, 
1998). Entretanto, a adaptação a perda vai se fazendo devagar e nesse processo a mulher volta a se perceber como inteira.

A gente não é só a mama. (GF)

A questão da dor no local da cirurgia não impediu que, devagar, o casal fosse redescobrindo essa mama como parte de suas carícias e as percepções e os cuidados foram diversos, dependendo de como o mesmo foi realizando essa reconstrução.

Uma das características do gênero feminino é o detalhe, a observação minuciosa sobre as pessoas, no entanto, neste estudo, os homens relatam diferenças, por eles observadas, na mama como:

"Diminuiu um pouco de tamanho". (GM)

"O que mudou foi a sensibilidade". (GM)

"No início ela ficou inchada, agora está igual à outra".(GM)

"Se apertar, ela sente. Eu sempre estou mexendo nela". (GM)

As mulheres também relatam diferenças:

"Eu acho que a sensibilidade mudou um pouco, eu fiquei com a mama dolorida. Está dolorida. A gente tem receio de não apertar, não machucar, de não forçar". (GF)

Mesmo cientes destas modificações, alguns homens mostraram dificuldade de aceitar essa mama operada, independente do fato de ter ocorrido a mastectomia.

"Eu não acariciei porque pode machucar". (GM)

"Do lado esquerdo, eu faço questão de não tocar". (GM).

"Eu tenho medo de machucar". (GM)

Essas dificuldades foram percebidas pelas mulheres, que aceitavam a situação sem questionar porque também tinham medo ou dor. O aumento da 
sensibilidade logo após a cirurgia foi relatado tanto por homens como por mulheres, o que despertou nos dois o sentimento do cuidado e levou a evitar o toque.

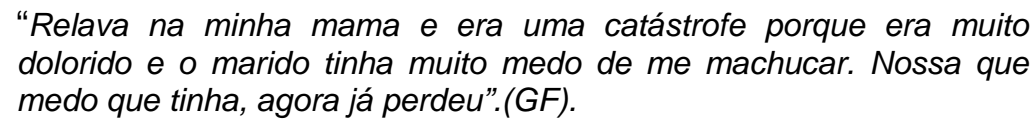

Um dos companheiros relata que a perda da mama da esposa representou uma perda para ele também, mas que havia outra compensação.

"Ter retirado o seio esquerdo, ele tinha sido para mim, uma parte dela que se perdeu, só que ao mesmo tempo eu era um dos poucos que poderia ouvir o coração dela bater tão forte, porque eu tinha uma parte, ali”.(GM)

O cuidado e a aceitação desse corpo modificado se configuraram como uma reconstrução particular e única e, mesmo entre aqueles casais bem entrosados, se deram em tempo diferentes.

Os profissionais de saúde devem favorecer a participação da mulher na escolha do seu tratamento, discutindo o tipo de cirurgia, o porquê desta escolha, os efeitos colaterais do tratamento, porque isso fará com que ela tenha uma aceitação mais positiva deste novo corpo (ARANTES, 2002; FUNG et al., 2000).

O companheiro deve ser estimulado a participar mais efetivamente do tratamento, freqüentando s consultas médicas, conversando com os profissionais de saúde sobre suas dúvidas, o que poderá facilitar a aceitação do novo nas mulheres mastectomizadas e a compreensão da hipersensibilidade da mama após uma cirurgia.

\subsubsection{O Toque}

O toque é um importante aspecto da intimidade entre um casal, porque faz parte do jogo amoroso, podendo levar a um ato sexual. Entretanto, o toque 
obrigatoriamente, não leva a um ato sexual, mas faz com que a pessoa tocada se sinta querida e acolhida pelo companheiro. Infelizmente, muitos casais perante o impacto de um diagnóstico de câncer, podem diminuir tal prática (HUGHES, 2000).

Em nosso estudo, a retirada da mama não foi empecilho para a prática do toque dos companheiros. O olhar, o tocar no local onde antes existia a mama foi relatado como uma necessidade do companheiro. Conhecer esse novo corpo significa também perceber as suas diferenças e o toque é um dos modos de interagir com o mesmo.

"Eu toquei, eu mexi porque eu tinha vontade. Eu acabei tocando, pondo a mão quando ela não sente dor".(GM)

Entretanto, nem todos os homens cujas mulheres foram mastectomizadas, tiveram vontade de explorar o local cirúrgico em que ocorreu a retirada da mama. Em nossa cultura, o local da cicatriz cirúrgica é tido como um lugar que não deve ser explorado por causa da preocupação com possíveis processos infecciosos e, quando o casal não tinha o hábito de se tocar as regiões erógenas do corpo, esse local passa a ser intocável.

"Eu não coloquei a mão porque não tive vontade".(GM)

Essa postura do marido é aceita pela mulher, pois relata que mama não fazia parte da rotina sexual do casal, porque ela era dolorida e não era tocada, assim a cirurgia não afetou o comportamento sexual.

"Essa mama minha sempre foi muito dolorida, tinha uma secreção amarelada e por isso ela não era acariciada".(GF)

A mama reconstruída não foi garantia de satisfação com o produto final produzido e a diferença foi percebida tanto pelos homens como pelas mulheres e, dependo de como os cônjuges perceberam essa nova mama, esse foi um fator que interferiu no incentivar ou inibir o toque. Em um dos casais, essa alteração despertou a necessidade do toque, de se conhecer essa nova mama, resguardando o cuidado 
de não machucar, mas de conhecer o novo, tendo a ciência de que ela é artificial, mas que no relacionamento sexual ela faz o papel de eroticidade para ele.

"Quando o médico liberou, eu peguei na mama. A sensação é a mesma e eu não vejo diferença".(GM)

Esse depoimento demonstra que, para esse homem, a reconstrução foi benéfica e favoreceu o toque. Sabemos que a reconstrução pode ser favorável para as mulheres, principalmente, se ela era mastectomizada há algum tempo. Estudos com mulheres sem reconstrução, mostram que elas têm dificuldades de tocar o local da cirurgia e que tendem a esconder a região do companheiro (SILVA, 1994; CLAPIS, 1996; RODRIGUES, 1999).

Houve, entretanto, homens que relataram dificuldade de aceitar o toque na mama reconstruída. A perda da mama para esse casal ocorreu de modo a ver que a reconstrução era boa, que o impacto seria positivo, mas que a realização da mesma não oferece o produto final idealizado. A opção da técnica cirúrgica na reconstrução da mama, associada à recuperação, a complicações no pós-operatório e talvez à falta de informação de que o resultado do procedimento cirúrgico é em longo prazo, talvez tenham sido os motivos da dificuldade de se aceitar essa nova estética.

"Passar a mão, fazer carícia, isso não teve não, não porque eu não tenha deixado".(GF)

"Eu não acariciei porque tenho receio, eu tenho medo. Você vê aquela situação, a mulher mutilada".(GM)

Esse medo não é verbalizado para a mulher e ela aceita a falta do toque sem questionar porque não tem outros instrumentos a não ser o silêncio e a espera do tempo do outro de aceitar que a mama reconstruída. Em nossa sociedade, a mulher foi culturalmente educada a não fazer questionamentos sobre as atitudes sexuais do companheiro e, no caso de haver uma mastectomia com reconstrução ou não, o fato de o marido não abandoná-la e procurá-la sexualmente é percebido como um fator 
positivo. No entanto, esse mesmo casal que teve dificuldade de aceitar a nova mama, relata que a vida conjugal após o câncer melhorou porque hoje eles têm mais tempo para ficarem juntos.

Entretanto, nas mulheres nas quais não houve a retirada da mama ,encontramos um casal em que ambos relatam dificuldade do homem em tocar a mama e que, com o passar do tempo, reaprendeu a tocá-la com o estímulo de sua companheira, com diálogo e que, hoje, o toque, voltou a fazer parte da rotina de carícias do casal.

"Ela deixa tocar, para ela não tem problema, mas eu tenho medo. As vezes eu dou uma apalpadinha para ver se eu acho caroço". (GM)

Essa situação foi percebida pela companheira que relata:

"Custou ele pôr a mão nesta mama, o dia que ele pôs, foi tão de levinho. Se eu não tivesse mostrado para ele quanto podia apertar, acho que até hoje ele não relava a mão nela de medo, mas hoje já passou. Hoje ele passa a mão com muito cuidado. Ele a acarinha." (GF)

O diálogo e o bom relacionamento foram fatores que levaram devagar a que o medo fosse diminuindo além do incentivo da mulher de conduzir a mão dele à mama operada e verbalizar que o toque para ela era importante.

Questionamos aos casais como era a sua relação com a outra mama, com aquela que não tinha apresentado câncer de mama.

Um homem afirmou que a sua maior dificuldade foi tocar a mama sadia também, pois tinha medo que a mesma adoecesse.

"Eu tenho medo de acariciar e achar alguma coisa". (GM)

O medo inconsciente de reviver a descoberta do nódulo, o diagnóstico do câncer, o tratamento, ainda se faz presente neste homem, porque, para ele, a situação vivenciada pode se repetir e como foi uma vivência traumática, o medo de ela se repetir, de como será a sua reação, é angustiante. 
Independentemente de ter sido retirada a mama, um homem relata que em decorrência da mama operada ser dolorida ele não toca nenhuma delas. A dificuldade em aceitar algumas limitações impostas pela cirurgia ou pelas esposas levaram alguns homens a posturas radicais, como o afastamento total de carícias nas mamas, o que pode comprometer a vida sexual do casal.

"Ela não deixa acariciar a mama operada porque diz que dói e eu não acaricio a outra porque tem que ser as duas". (GM)

Essa postura ocorreu em três homens e as mulheres aceitam esse gesto, por não saberem como trazer esse assunto à discussão ou por entenderem que elas devem aceitar essa situação, mesmo que, para elas, o toque da mama seja importante. Repete-se o papel feminino de submissão às vontades dos homens, não questionando as suas próprias necessidades de afeto e toque.

Entretanto, nos outros casais, a outra mama continuou a configurar elemento importante na rotina das carícias sexuais do casal e, com a recuperação da mulher, ao término do tratamento, a mama operada voltou à fazer parte dessa configuração:

"Na outra mama ele faz aquele carinho, dá uma apertadinha". (GF) "Ele coloca a mão na outra mama". (GF) "A preferência é a outra mama na hora do sexo, essa é só para massagear e olhar". (GM)

"A gente acaricia igual às mamas". (GF)

Esses casais parecem ter conseguido superar nas atividades sexuais, a experiência de vivenciar o câncer e a mama operada é acariciada. No entanto, a mama sadia é aquela preferida como objeto de carícias durante o ato sexual, especialmente porque não oferece desconforto para a mulher. 


\section{3. - O exercício da sexualidade dos cônjuges que vivenciaram o câncer de mama}

A sexualidade é algo inerente ao ser humano e nos acompanha durante toda a nossa vida, sendo que está presente no nosso modo de ser. O exercício da sexualidade engloba o relacionamento sexual que pode perdurar por toda a vida da pessoa ou sofrer alterações devido a fatores internos e externos. Os fatores externos estão ligados a espaço físico para sua execução, às interferências de outras pessoas e, os internos, incluem patologias ou medicações que interferem no desejo, no funcionamento dos órgãos genitais ou no aspecto psicológico.

Sabemos que, quando as pessoas adoecem, elas tendem a ter uma desatenção para as atividades lúdicas e para atividades que estão relacionadas ao prazer, à alegria de viver e, às vezes, comprometem sua qualidade de vida. $\mathrm{O}$ relacionamento sexual é um dos aspectos que podem ficar comprometidos e os profissionais de saúde geralmente não dão ênfase nesse aspecto por falta de formação adequada para essa abordagem, seja por não considerá-la importante ou pelo fato de a pessoa doente ficar inibida de realizar questionamentos sobre essa área.

Entretanto, sabemos que a doença não é um obstáculo para o exercício da prática sexual, ficando na dependência do estado geral e do tipo de tratamento a que se é submetida e também à qualidade do relacionamento do casal.

No caso de mulheres com câncer de mama, há alteração direta em um órgão tido como erótico e ligado à prática sexual. Estudos sobre a sexualidade em mulheres mastectomizadas afirmam que a auto-imagem delas fica alterada e que isto é um fator que interfere no exercício da sexualidade (CLAPIS, 1996, SILVA; MAMEDE, 1998, ROSSI; SANTOS, 2003). 


\section{Diagrama 2 - O EXERCÍCIO DA SEXUALIDADE DOS CÔNJUGES QUE \\ VIVENCIAM O CÂNCER DE MAMA}

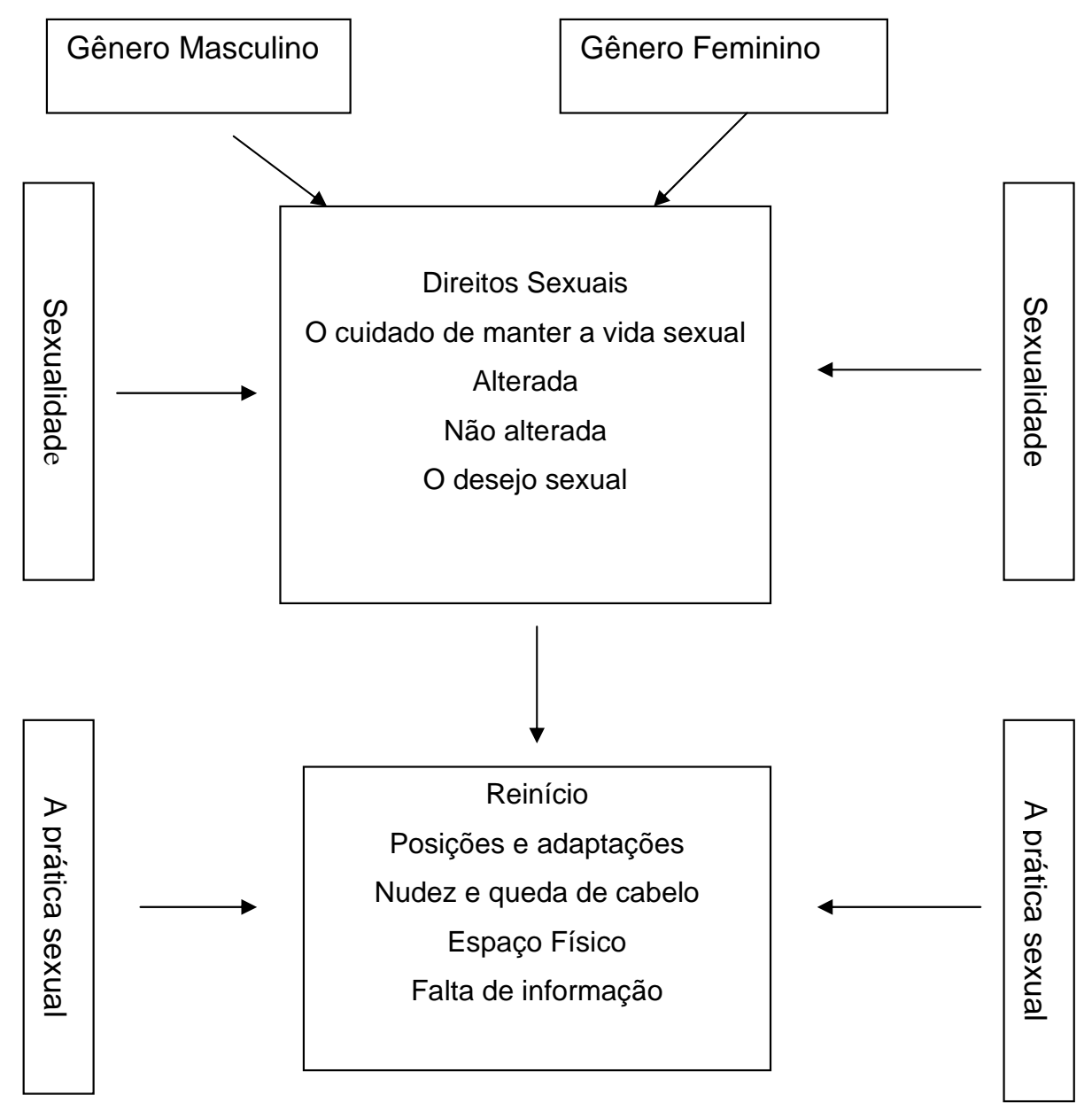

O diagrama 2 é uma síntese do objeto desse estudo e foi subdividido para facilitar a compreensão dos dados encontrados. 


\title{
4.3.1 A sexualidade masculina e feminina
}

A sexualidade sofre influências do meio ambiente em que vivemos e os valores que nos são transmitidos em nossa criação vão influenciar no exercício da mesma.

A sexualidade masculina em nossa sociedade é extremamente valorizada. $\mathrm{Na}$ adolescência, ela é incentivada para marcar a masculinidade e, em outras etapas da vida do homem, é cultuado que ele têm necessidades sexuais maiores que as mulheres e que por isso tendem a ser mais promíscuos ou ter relacionamentos extraconjugais.

Em nossa sociedade, a mulher ainda tem a sua sexualidade preservada e mesmo que não chegue ao casamento virgem, ela é incentivada para se preservar do contato sexual por mais tempo do que os homens, que na adolescência são incentivados a iniciarem a vida sexual para provarem que são homens.

Heilborn (2004, p. 10) relata que:

\begin{abstract}
os traços mais específicos da modernização dos costumes sexuais se referem em especial às mulheres: a perda do valor da virgindade feminina; o alongamento da vida sexual, a ampliação do leque de práticas sexuais aceitáveis. Os homens não estão fora desse cenário, mas comparece de maneira menos espetacular: as carícias preliminares no ato sexual propriamente dito passaram a integrar um ideal de comportamento. Todos esses elementos entrelaçados configuram o papel central que a sexualidade ocupa na construção de si na contemporaneidade e que fez dela o motivo e o esteio das relações conjugais.
\end{abstract}

Esse padrão sóciocultural pode sofrer transformações conforme o relacionamento dos casais é construído. O partilhar de formar uma família e o viver social leva a uma construção da sexualidade do casal. Assim, um casal realiza a sua intimidade sexual dentro do casamento, que o levará a ter postura ética perante situações de privação ou diminuição do ato sexual. 
Em situações em que há a existência de uma patologia, esta irá influenciar em nossa sexualidade e pode ser que algumas pessoas modifiquem o seu padrão sexual em função da mesma, mas essa alteração será em relação a um padrão préexistente.

Em nossa sociedade, desempenhamos papéis que são mais ou menos esperados para cada sexo, visto que desde a infância somos criados para desenvolvê-los na idade adulta.

Nascemos machos ou fêmeas, mas aprendemos a ser meninos e meninas para chegarmos na fase adulta como homens e mulheres por termos aprendido os comportamentos e atitudes apropriados, os papéis e atividades adequados a cada sexo e como devemos nos relacionar com outras pessoas. Esse comportamento aprendido é que organiza a identidade de gênero e determina os papéis de gênero que iremos reproduzir na sociedade (WILLIANS; SEED; MILAU, 1999).

Durante a nossa vida, porém, esses papéis podem ser modificados porque a cultura e a sociedade são dinámicas e, devido às grandes mudanças tecnológicas, a globalização de conhecimentos, novos valores podem ser agregados a nossa vida e modificar alguns papéis. Um fator que pode modificar esses papéis acontece quando um dos membros da família adoece, o que leva outros membros a assumir o papel do outro. Assim, fatores como guerra, morte, doença, idade, raça, cultura são padrões que interferem nesses papéis e podem gerar mudanças.

Em nosso estudo, observamos que alguns arranjos e posturas de gênero foram modificados para o bem-estar da família. Como trabalhamos com casais, era esperado identificar papéis masculinos e femininos construídos socialmente. 
Entretanto, encontramos homens extremamente sensíveis e que foram capazes de discutir seus pontos de vista e criar situações para o bem-estar de suas companheiras.

\subsubsection{Igualdade sexual}

Apesar de a mulher moderna ter mudado seu comportamento na esfera sexual, nem todas procuram seus parceiros no sentido sexual. Esse comportamento está ligado a como a pessoa foi educada e como é a relação com o seu companheiro. Nesse grupo de estudo, a única mulher que não procura sexualmente o marido relata que foi devido a sua criação; as demais dizem que o fazem, mas que, para algumas, foi um aprendizado dentro do relacionamento conjugal.

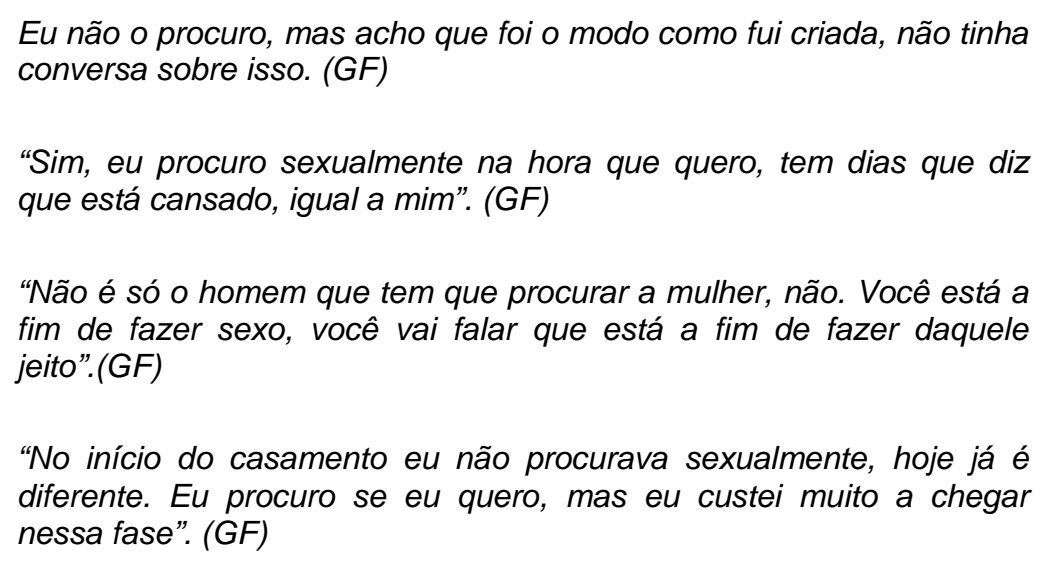

"No início do casamento eu não procurava sexualmente, hoje já é diferente. Eu procuro se eu quero, mas eu custei muito a chegar nessa fase". (GF)

Entretanto, uma das mulheres afirma que não procura o marido sexualmente porque ele não aceita.

“Eu não procuro não. Ele falou que não era para procurar e eu não o procuro. Fica na vontade dele".(GF)

As mulheres são educadas para serem passivas dentro do relacionamento sexual e que cabe ao homem o início de atitudes que terminarão no ato sexual. Como atualmente a liberação sexual é maior, há uma mudança do comportamento 
da mulher e ela passa também a buscar o marido, quando está com desejo sexual, deixando para trás aquela educação que reprimia a mulher sexualmente.

Os homens não relataram essa igualdade, mas afirmaram que têm necessidades sexuais e que as mulheres correspondem a elas, mas que eles também sabem esperar.

"Não é porque ela está doente que eu não tenho direitos na vida sexual. O vigor masculino é maior" (GM)

"Ela sabe das minhas necessidades, então ela tem muito boa vontade".(GM)

Entretanto, o discurso de que homens têm maiores necessidades sexuais aparece, mostrando que esse é um fator preponderante para as mulheres pensarem que eles precisam de atenção e de atividade sexual. Essa fala leva a ver que as mulheres acabam servindo seus homens, mesmo não estando muito dispostas porque eles não estão doentes.

Bozon (2004) relata que atualmente não se concebe um casamento sem atividade sexual dos seus cônjuges, visto que ela é a expressão do impulso mútuo dos mesmos e que a ausência de relações sexuais põe em perigo a estabilidade da construção conjugal, inclusive quando se tem problemas de saúde ou se envelhece.

Uma das mulheres comenta que essas mudanças relacionadas ao papel da mulher na atividade sexual, especialmente quanto à iniciativa do ato sexual é satisfatória, visto que em relacionamentos anteriores a esse, ela vivenciou essa situação de ser rechaçada pelo marido, sendo que o mesmo colocava que a decisão pelo sexo é coisa de homem.

"Quando eu procurava ele, a casa caía. Você está parecendo prostituta, a mulher nunca deve procurar o homem e eu ficava inibida". (GF) 
Apesar de os homens exporem que têm necessidades sexuais maiores que as mulheres, eles também deixaram em evidência que sabem o momento que elas estiveram prontas para retornarem a vida sexual e que isso não trouxe nenhuma revolta, visto que eles se colocavam como companheiros e souberam esperar.

"Eu espero ela me responder sim".(GM)

"Você tem que esperar o momento dela. Tem que fazer quando ela quer" (GM)

"Ele esperou numa boa, sem ficar emburrado ou insistindo e não ficando com raiva". (GF)

"Teve uma pausa prolongada por causa do tratamento, depois não tinha o desejo e ele esperou bastante. Ele respeitou pra caramba mesmo, se eu não tivesse passado tudo o que eu passei, mas ele soube esperar". (GF)

Outro fator importante para os homens foi exercitar a função social esperada deles, de protegerem, serem fortes e suportar esse período com respeito a sua companheira. Situações de abandono são descritas por eles como algo que não deve acontecer mesmo sendo difícil para alguns passarem pelo problema de conviver com a esposa doente. Estar ao lado da companheira em uma hora difícil é função deles, que reforça o papel masculino de protetor.

"Se homem abandona a mulher nesta hora, ele não é homem. O abandono acaba matando a mulher".(GM)

"A gente conhece um cara que falou para mulher: vou embora, vou embora, largou ela e foi embora".(GM)

"Eu tenho um vizinho que quando a mulher adoeceu ele foi embora". (GM)

Atitudes de abandono da mulher no momento da doença são relatadas pelos homens como um fator de fraqueza e de falta de caráter e que fere a masculinidade 
Afirmam também que a mulher teve uma força muito grande para enfrentar a doença e os problemas familiares que ocorreram em conseqüência da mesma e até muitas vezes a "barra" deles.

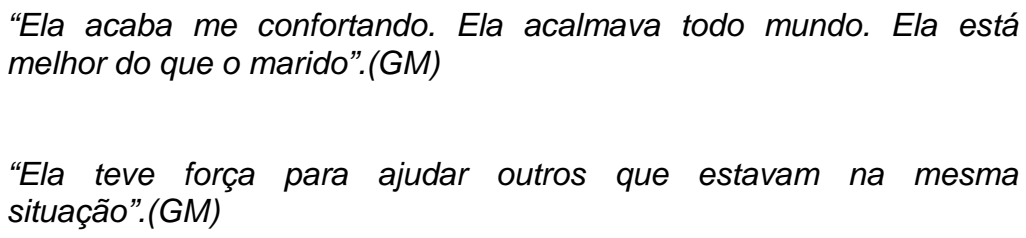

Mulheres que tem um diagnóstico de câncer de mama tendem a demonstrar uma força no sentido de vencer a doença e, inicialmente, podem parecer mais fortes do que realmente estão se sentindo (WANDERLEY, 1994).

Neste grupo de estudo, as mulheres reforçaram atitudes que representam expectativas culturais para o gênero feminino como atitudes de conforto, de acalmar e de dizer que tudo iria acabar bem.

Dentre os papéis femininos determinados pela sociedade para a mulher, o cuidado com a casa é de sua responsabilidade, assim como a educação e a criação dos filhos e o bem-estar da família. Sendo a administradora da casa e se preocupando com o bem-estar de todos, mesmo quando ela adoece, continua se preocupando com todos os familiares.

"Eu sou mais frágil que minha esposa. Ela resolveu os problemas meus, os dela e se precisar de mais uma porção de gente". (GM)

A mulher na nossa sociedade é tida como o sexo frágil, aquela que deve ser protegida e afastada dos perigos. Neste estudo, as mulheres se mostraram fortes, decididas a vencerem a doença e a enfrentar qualquer coisa para se restabelecerem fisicamente, retornarem o seu papel de esposa e acabam cuidando de todos os membros da família. 
Essa expressão de cuidado se fez presente em mulheres que tiveram o diagnóstico do câncer mais jovens. Para algumas não ter filhos foi um alívio saber que ninguém dependia dela.

"Acho que dessa vez eu não vim para ser mãe. Eu tive o câncer com 44 anos e se eu tivesse sido mãe eu teria filho pequeno. Por eu não ter filhos a minha situação foi mais tranqüila um pouco, por eu não ter nenhum menor dependendo de mim". Quem tem filho pequeno dá uma angústia muito grande com um diagnóstico deste" (GF)

Para as que tinham filhos pequenos, foi um fator de preocupação com o futuro deles e com a sobrevivência delas.

"Eu queria ficar bem, não só para cuidar de mim, mas para cuidar deles (filhos) também, que eram pequenos". (GF)

"Eu pensei no meu filho mais novo. Talvez eu pudesse morrer e eu vivi tão pouco tempo com meu filho".(GF)

Estudos têm demonstrado que mulheres que tiveram um câncer de mama e que têm crianças pequenas preocupam-se se elas sobreviverão tempo suficiente para vê-los adultos, com o sustento dos filhos e com isso experienciam um estresse adicional para manter o papel de cuidadora (ANLLO, 2000).

Entretanto, a questão do cuidado com os filhos e com a companheira pelos homens, se fez presente no relato deste grupo de estudo.

O cuidar é tido como uma tarefa feminina, ligada à mãe. Mas o cuidado "nasce de um interesse, de uma responsabilidade, de uma preocupação, de um afeto, o qual inclui o maternar e o educar, que por sua vez, implicam ajudar a crescer" (WALDOW, 1999. p. 51).

"Ou bom ou ruim, mas ele me cuidou, ele me cuidou. ele cuidou, porque ele me acompanhava na quimioterapia, porque eu passava, eu saía do hospital passando mal".(GF)

"Ele cuidou, na medida do possível, ele cuidou, porque ele cuidou não só de mim, porque os meninos na época eram pequenos, ele também 
cuidou deles porque tinha que mandar pra escola, tinha, que nem o mais novo que tinha que ter mais cuidado, pra poder na hora de dar o banho, não foi fácil não mais".(GF)

"E depois que eu vim aqui pra casa aí era ele. Ele me ajudava a levantar, me ajudava a deitar, me ajudava a tomar banho. Aí era ele".(GF)

Cuidar é um ato de responsabilidade e de afeto e é intrínseco ao ser humano, porque assim como ele cuida, ele necessita de cuidados, seja físico, psicológicos e emocionais, cuidado que os homens souberam oferecer.

Mas o papel mais exercido pelos homens foi o de motorista, visto que as mulheres não acham importante eles a acompanharem durante as consultas, a quimioterapia, o que favoreceu a falta de informações por parte deles.

Para as mulheres, ter o marido como acompanhante não era uma necessidade e, sim, uma perda de tempo, afinal, homem deve ir trabalhar. Reforçava-se, assim, o papel esperado do homem provedor, responsável pelas atividades públicas.

"Ele vai ficar lá perdendo tempo? Não tem necessidade. A primeira vez ele ficou porque ele não sabia a reação, não sabia nada. Depois as outras eu falei que não tinha necessidade".(GF)

"Ele que me acompanhava na quimioterapia e eu preferia que ele ficasse ali fora conversando porque assim às horas passavam mais rápido". (GF)

"Eu nunca quis que ele ficasse lá e ele queria ficar. Não eu sabia que se ele ficasse, ficaria preocupado com o trabalho". (GF)

"Nunca foi porque ele trabalhava e eu sempre fui uma pessoa muito independente e assim eu sempre fiz tudo sozinha".(GF)

Chamou-nos a atenção é que os companheiros assumiram um papel tido como masculino - o de motorista. Quase todos iam levar e buscar as esposas ao médico, à quimioterapia, à radioterapia, mas poucos ficaram de acompanhantes. Esse papel foi reforçado pelas mulheres. 
"Ele me levava e eu nunca deixei ele ficar no hospital comigo e me buscava. Quando terminava a quimio, eu ligava, ele largava o que estava fazendo e ia me buscar".(GF)

"Foi sempre ele que me levou e me buscou. Quando terminava a rádio ou a quimio, ele já estava lá".(GF)

"Na quimio, ele me levava e me buscava, mas não agüentava ficar lá não".(GF)

Holmberg et al. (2001) relatam em seu estudo que os companheiros eram responsáveis pelo transporte de suas esposas para a clínica e que normalmente estavam presentes nas consultas médicas e no tratamento indicado e que achavam que isso era muito importante para suas esposas. Em nosso estudo, poucos maridos acompanharam suas mulheres à consulta médica, mas foram responsáveis pelo seu transporte.

\subsubsection{O Cuidado de manter a vida sexual}

Apesar de as mulheres de não se sentirem bem, de não estarem interessadas em fazer sexo, elas referem saber das necessidades sexuais dos companheiros e que procuram dentro do possível atendê-los, mesmo que a relação não seja satisfatória para elas.

"Sempre que você me procurava, eu estava disposta a te servir, eu nunca te recusei“.(GF)

"Eu aceito ele, a hora que ele vier, eu aceito, mesmo que eu não esteja com vontade. Só para satisfazer ele". (GF)

Uma das mulheres acha que a necessidade sexual do homem é maior do que a da mulher e, por acreditar nisso, liberou o seu marido para ter um relacionamento fora do casamento.

"Eu falei pra ele, eu estou doente, você não. Se você quiser arrumar uma pessoa para você sair com ela, você usa a camisinha porque 
quem está doente sou eu. Eu ia deixar ele ficar na situação que ele estava? Não era justo". (GF)

Fato esse confirmado pelo companheiro:

"A minha esposa me liberou para arrumar outra mulher".(GM)

Outra mulher refere que não vê a necessidade sexual masculina diferente, que acha que são eles que se posicionam como diferentes, porque têm medo de não satisfazerem suas mulheres por apresentarem problemas de ereção e o colocam como primordial pelo medo da traição.

"Eu nunca fui homem, mas não sei se a necessidade é maior do que a nossa, eu acho que não, que não tem necessidade. Ele já apresentou algumas dificuldades de ereção, por isso eu acho que fui acomodando, porque o sexo não é tudo no casal, é importante sim, mas não é tudo".(GF)

O fato da mulher se referir com menos necessidades sexuais não significa que isso seja verdade, mas culturalmente ela é criada e educada para ser mais reservada e não demonstrar o seu desejo, o que é facilitado pela própria anatomia.

Quanto à liberação do companheiro para atividades extra-conjugais, pode ser um modo de controle do outro e a liberação funcionar como uma falsa liberdade e aumentar a responsabilidade do companheiro de compreensão e espera do momento em que ela esteja apta para voltar a ter relações sexuais.

A submissão das mulheres à vontade sexual de seus maridos aparece neste estudo, porque fica claro que, mesmo não tendo muito interesse pelo sexo naquele momento, elas compreendem a necessidade deles, apesar de muitas vezes questionarem se eles não podiam ficar sem o sexo. A esse fato os homens respondem de modo oposto entre si.

"A mulher vai perdendo um pouco ânsia, daquela coisa, principalmente de fazer sexo... Elas gostam de servir (sexualmente) o melhor possível". (GM)

"Não estou passando fome hoje porque eu comi bem algum tempo e estou gordinho, eu posso ficar sem comer". (GM) 
Bozon (2004) relata que o comportamento sexual é percebido a partir de categorias de atividade e passividade, estando associadas ao masculino e feminino e que se espera que o homem tenha o papel de ativo, por isso a metáfora de que ele "come" e a mulher "dá".

As questões de vigor estão associadas culturalmente ao fato de que a mulher envelhece e de que, quando passa pela menopausa, ela estará envelhecida e seu vigor sexual não será o mesmo. Sabemos que alterações fisiológicas ocorrem nessa etapa da vida da mulher, que levará a uma diminuição dos hormônios sexuais e que influenciará na libido, mas se o casal tiver tido anteriormente uma vida sexual satisfatória, o número de relações poderá diminuir, mas não deixará de existir.

Como o relacionamento sexual é uma coisa esperada dentro do casamento, o homem cobra da esposa esse servir, pois a mulher brasileira não foi educada para criar meios de negociação com os parceiros nesta área. Então, ela acaba não negociando a sua necessidade sexual e se submetendo à vontade do parceiro, com medo de ser traída.

Em nossa sociedade, a questão da traição é mais um discurso masculino do que feminino, mesmo sabendo que ambos podem trair.

Neste estudo, nada foi perguntado sobre a traição. No entanto, a maioria dos homens relataram que, se a vida sexual do casal não é boa, o homem vai buscar sexo fora do casamento e que essa é uma arma que tece o relacionamento entre os casais, levando um a se preocupar com as necessidades sexuais do outro, para não traírem ou serem traídos. Os homens colocam a traição como um discurso masculino, mas negam que tenham traído suas esposas em qualquer momento.

"O desinteresse sexual da mulher leva o homem a procurar outra mulher".(GM) 
"Eu nunca arrumei outra mulher, nunca a traí, mesmo ela tendo me liberado".(GM)

"Se a gente não se preocupa e não se esforça para ter relação, ele pode ter relacionamento lá fora, é isso que a gente preocupa".(GF)

"Eu não estava muito a fim... Eu procurava fazer a minha parte”.(GF)

Observamos que a traição é um fato que paira como uma sombra durante um relacionamento e as mulheres, mesmo não estando muito dispostas para a prática sexual, perante o medo de ser traída, se dispõem ao ato sexual para que outra mulher não ocupe o seu lugar.

Um dos homens relata que traiu a mulher, mas afirma que esse fato não tem nada a ver com ela ter tido um câncer de mama e, sim, com o relacionamento ruim que eles tinham. Conta que é um segredo, mas a mulher descreve claramente que conhecia as traições do marido.

"Teve uma outra mulher". "Eu sempre considerei que ele é pai dos meus filhos, eu respeito ele, apesar de muitas vezes, ele já aprontou muito comigo...ele já aprontou... oh, ele já foi muito danado, ele já aprontou muito comigo. Eu posso até perdoá-lo, mas eu não vou esquecer o que ele fez comigo, porque eu sempre o respeitei". (GF)

Para muitos casais a conservação do relacionamento, apesar de conflituoso é o mais importante porque o casamento foi um juramento para toda a vida. Esse casal, apesar dos conflitos, continuarão juntos por causa da concepção que a mulher tem do casamento e que força o marido a assumir responsabilidades.

"Eu vou conseguir a minha casa, e vai ser com você, você vai trabalhar pra ajudar a criar seus filhos, porque você tirou eu da casa da minha mãe, você não pegou eu na rua não". (GF),

Nolasco (1993, p. 142) nos relata que a traição

antes de ser um comportamento moral, é fruto de um mecanismo inconsciente que protege o indivíduo de realizar, mesmo no plano imaginário, um desejo proibido. O processo de deserotização e dessexualização da relação com a mulher se inicia pelo deslocamento do lugar que ela ocupa como "mulher" para um outro em que ela vai recebendo atributos e qualificações maternas. 
Em nosso estudo, encontramos alterações e identificamos alternativas que esses casais foram utilizando para superar os obstáculos enfrentados no decorrer do tratamento do câncer.

\subsubsection{A sexualidade alterada}

Independentemente do tipo de cirurgia a que mulher foi submetida para a retirada do tumor na mama, as mulheres perceberam alterações em sua sexualidade e afirmaram que essas alterações foram percebidas pelos homens. Os casais descrevem como foram se adaptando e resolvendo as alterações que surgiram no transcorrer da doença. Entretanto, uma mulher afirmou que a doença levou a apresentar alterações que, no momento da entrevista, a estavam impedindo de exercer a prática sexual e um dos homens ficou tão abalado com a doença da esposa que apresentou alterações na resposta sexual. Ambos tiveram alterações no desejo, que é um dos fatores estimulantes para a prática sexual.

\footnotetext{
"Eu acho que houve mudança na minha vida sexual, na minha parte, a dele está inteira. A minha sexualidade que está alterada. Eu estou muito fria, uma geladeira, estou sempre procurando uma desculpa. Eu estou tão sem vontade de fazer sexo que às vezes eu até evito fazer a automassagem, só para não assanhar ele". (GF)

"Durante o tratamento ela não estava disposta para o sexo...Fica sem tesão por causa do tratamento". (GM)
}

Compreender o que está acontecendo com o corpo e com a mente, durante ou após o tratamento, contribuiria para melhorar a reação que os casais percebem. O fato de não terem informações de que essas são respostas esperadas durante o tratamento leva a um afastamento um do outro, sem que essas dúvidas sejam explicitadas. Nesses casos, as diferenças entre os gêneros aparecem com clareza. 
As mulheres evitam criar situações que estimulem seus companheiros a ficarem excitados e os homens tentam se manter distantes das mulheres, como se fosse um abuso por parte deles eles desejarem ter um relacionamento sexual com elas.

As duas atitudes reafirmam as diferenças de gênero; ela, se posicionando como o objeto do desejo e acreditando que se não estimulá-lo, inibirá seu desejo sexual. Ele, por sua vez, se mantém longe sexualmente e não expõe suas necessidades sexuais, em respeito ao estado da companheira. A desinformação sobre o tratamento e seus efeitos também são responsáveis por essa situação, mas percebemos que a atitude de busca por orientações se fez mais entre as mulheres, talvez por elas participem do REMA. Assim, a informação passa a ser do domínio feminino e a mulher detentora desse saber passa a ter um domínio maior do que o homem, sobre quais alterações podem ocorrer durante o tratamento,

Se o casal mantém um diálogo sobre as informações que a mulher recebe, esse conhecimento será transmitido para o homem. Entretanto, se isso não ocorrer, a mulher pode controlar os impulsos sexuais do companheiro, dizendo que está doente e exercendo o seu conhecimento e repetindo as relações de poder na sexualidade, mas de modo inverso, visto que em nossa sociedade o exercício da sexualidade é masculino.

Foucault (1988) relata que nas relações de poder, a sexualidade não é o elemento mais rígido, mas um dos dotados de maior instrumentalidade, utilizável no maior número de manobras, e podendo servir de ponto de apoio, de articulação às mais variadas estratégias.

Assim, as mulheres, tendo acesso a informações podem controlar a sexualidade de seus parceiros, mas como os casais demonstraram um relacionamento afinado, não observamos o exercício desse poder entre os cônjuges. 
Uma das mulheres estudadas referiu que percebeu alterações na sua resposta sexual; no entanto dizia ter dúvidas acerca da sua origem, ora relacionando-a ao câncer, ora ao envelhecimento e, por carência de informações sobre as alterações da libido, diminuição da lubrificação vaginal entre outras decorrentes à quimioterapia, a deixava insegura:

"Eu acho que mudou. Eu fiquei bem mais fria, não sei se foi o câncer ou a idade, não sei lhe explicar o porquê".(GF)

Alguns estudos com mulheres mastectomizadas relatam que elas percebem mudanças em seu relacionamento sexual. Afastamento do parceiro, dor na mama, diminuição da libido, ressecamento vaginal são apontadas como mudanças negativas. Para outras pessoas, não há a diminuição da lubrificação vaginal nem a alteração da libido e, se têm o apoio do cônjuge, a sexualidade ficará afetada mais nos dias da realização da quimioterapia. As mudanças também são influenciadas pelo tipo de relacionamento que existia anteriormente com o companheiro, a influência que o câncer provoca na auto-imagem, as dimensões da autopercepção, como era a sua resposta sexual e se têm acesso a informações, além do diálogo entre o casal (HOLMBERG et al., 2001; DUARTE; ANDRADE, 2003).

Em casais que já apresentavam problemas no relacionamento ou na esfera sexual, a doença serviu como suporte para o companheiro não assumir que estava tendo disfunções sexuais. O surgimento da doença serviu como uma desculpa para os acontecimentos e ficou sendo a responsável pelos problemas de disfunção sexual masculina e que, somente agora, com o passar do tempo, o homem assume.

"No meu relacionamento, o problema maior foi comigo, eu acho que o maior problema foi comigo. Eu acho que eu preciso de tratamento. Porque ela está inteira".(GM)

Em nossa cultura, o homem tem dificuldade de assumir as disfunções sexuais porque isso o tornaria menos homem perante a sociedade. Isso gera um fator de 
sofrimento em que ele tenta ter relações sexuais, mas não consegue manter a ereção por tempo suficiente para satisfazer a mulher ou ejacula precocemente. Esse fato pode ocorrer devido ao envelhecimento, ao estresse, a problemas circulatórios e psicológicos e ele se agrava porque o homem demora em buscar ajuda, quando a mulher o procura (OLIVEIRA, 2000, ROSENTHAL, 2004). Neste estudo, a mulher o estimulava a procurar ajuda, porque ela tinha necessidades sexuais, mas isso não ocorreu.

"Se eu quisesse, se fizesse um carinho ou coisa assim, sei lá o que batia na mente dele, ele virava pro outro lado e dormia e eu ficava ali. Muitas das vezes eu falava: você precisa dar um jeito, você precisa se cuidar, precisa ir ao médico".(GF)

Nesse caso, a mulher tem uma atitude de espera e de submissão porque, mesmo tendo necessidades sexuais, o seu papel feminino é aceitar essa situação, Mesmo que ela fique revoltada e estimule o companheiro a buscar ajuda, ela não busca outros parceiros, apesar de ficar evidente que a doença não interferiu no seu desejo.

"A gente aceita tudo, só que às vezes ele tem as dificuldades dele também. Muitas das vezes, ele ia me procurar, ele não conseguia. É muita dificuldade, sabe, então, aquela paciência, quando pensava que tava tudo bem, pronto! Já? Rápido, não tinha jeito mais". (GF).

Para os demais casais, houve alguns momentos em que a prática do ato sexual ficou comprometida, mas relatam que as mesmas estavam relacionadas à recuperação da companheira durante o tratamento. Apontam que o período mais difícil e em que perceberam alterações na esfera sexual foi o da quimioterapia.

Sabemos que a quimioterapia é responsável por causar efeitos nos órgãos reprodutores como ressecamento vaginal, alteração na produção dos hormônios sexuais e, conseqüentemente. a suspensão do ciclo menstrual, levando a mulher a uma menopausa precoce.

Além disso: 
os quimioterápicos antineoplásicos podem levar a alterações relacionadas à fertilidade e à função sexual, cuja intensidade vai depender da dose, duração do tratamento, sexo e da idade. No homem ocorre oligoespermia e na mulher irregularidade no ciclo menstrual e amenorréia. É comum ocorrer diminuição da libido que pode ser atribuída a vários fatores tais como: auto-imagem comprometida, fadiga e ansiedade (BRASIL, 2003, p. 300).

O efeito colateral na área sexual mais relatado em nosso grupo foi o ressecamento vaginal em graus diferenciados, além da interrupção da menstruação que interferiu na prática do ato sexual, segundo as mulheres:

"A primeira dificuldade que eu fui ter na área sexual é quando eu comecei a fazer a quimioterapia".(GF)

"Eu tive ressecamento vaginal, mas não foi coisa séria".(GF)

"Eu tive ressecamento, mas já está melhorando, nesta última relação eu já senti que está melhorando, nem precisou usar o gel".(GF)

"Durante a quimioterapia parou a menstruação e eu tive ressecamento".(GF)

"A única coisa que mudou é porque a gente resseca e não tem mais menstruação".(GF)

O ressecamento vaginal citado pelas mulheres também foi percebido pelos homens e os casais relatam que buscaram alternativas para amenizar o problema.

"Ela ficou ressecada. Você põe a mão e está seco, ressecado". (GM)

"Ela queixou uma vez, que estava áspero, ardendo". (GM)

"Ela teve dificuldade na lubrificação vaginal". (GM)

"Ela ficou ressecada. Às vezes dói”. (GM)

Uma das alternativas para minimizar os efeitos do ressecamento vaginal é orientá-los a utilizar lubrificantes hidrossolúveis quando apresentarem dispareunia, além de conversar que durante a quimioterapia algumas disfunções sexuais podem ocorrer, sendo importante ressaltar que essas alterações são transitórias (BONASSA, 2000). 
Observamos no grupo que a atitude de procurar alternativas para a solução do problema sexual foi para a maioria a utilização de lubrificantes vaginais.

"Está ressecado? Vamos comprar uns cremes". (GM)

"A gente usa um produto de lubrificação".(GM)

"O ressecamento eu preveni usando um lubrificante porque a gente fica muito ressecada. Eu comecei a usar e foi uma beleza".(GF)

"Quando tive ressecamento a gente usou um creme, um negócio que é próprio para umedecer mais. Agora não está nem precisando".(GF)

Outras alterações físicas são provocadas pela quimioterapia, sendo as mais comuns: a náusea, o vômito, febre, fadiga e o mal-estar geral. Esses efeitos colaterais foram percebidos pelo casal e citados como um período de espera tanto para a vida sexual como para o retorno das atividades de cada um.

"Nos dias que eu tomava a quimioterapia, tinha muita náusea, ficava aquele gosto horrível na boca. Não dá reação física, mas Ihe dá uma memória do remédio, que a hora que você lembra, você sente o gosto, você vê a pessoa que Ihe aplicou, você sente aquele gosto".(GF)

"A quimioterapia me acabava, a boca ficava ruim e eu vomitava muito; após 3 dias, usando medicação melhorava".(GF).

"Durante a quimioterapia, nas últimas a gente foi evitando ter relação porque eu não estava bem".(GF)

"Durante a quimioterapia eu procuro me afastar um pouco até ela se recuperar".(GM)

A quimioterapia é vista como prejudicial ao funcionamento sexual, talvez porque cause deficiência ovariana, levando a uma menopausa precoce abrupta em mulheres com idade pré-menopausa. A falência ovariana resulta do decréscimo de estrógeno e testosterona, que são associados com a atrofia vaginal, decréscimo de lubrificação vaginal e vasocongestão e decréscimo da libido (MEYEROWITZ et al., 1999). 
Neste estudo, tanto os homens como as mulheres identificaram o ressecamento vaginal, a dispareunia, a falta da menstruação no período da quimioterapia, mas desconheciam que esses eram efeitos colaterais do tratamento.

O ressecamento também foi citado por mulheres que não o tiveram na quimioterapia e, sim, quando começaram a utilizar o tamoxifeno.

"Eu não tive ressecamento na quimioterapia. Eu senti a diferença quando eu comecei a tomar o tamoxifeno".(GF)

Outra mulher relata que teve ressecamento após utilizar o tamoxifeno e mesmo tratando não houve melhora, além de apresentar vários efeitos colaterais.

"Ele (o médico) deu um gel para usar no relacionamento e usei uma pomada por 10 dias, porque mesmo sem ter relação, a vagina estava ressecada. Sabe quando a mão ou o pé resseca, racha e sangra? Assim estava a danada".(GF)

O tamoxifeno é um SERMs (moduladores seletivos dos receptores estrogênicos) que são utilizados como tratamento coadjuvante em mulheres que tiveram um câncer de mama, no sentido de diminuir a recorrência de tumores na mama contralateral e metástases. Podem apresentar, como efeitos colaterais, a menopausa precoce, disfunções sexuais, ressecamento vaginal, ondas de calor (MENKE, 2000; NAPACAN [2002?]).

Anllo (2000) refere que, enquanto a mulher estiver sob o choque inicial do diagnóstico, ela se submeterá à cirurgia de desfiguração da mama; em recuperação da mesma, receberá a quimioterapia que a debilitará, podendo levá-la a ter náuseas, perder os cabelos, causar menopausa precoce e levar à perda da função sexual. As mulheres agem sem pensar nesses efeitos colaterais porque, naquele momento, temem a morte e o câncer mais do que de perder suas mamas, seu cabelo, sua fertilidade ou sua função sexual. Esse desvio da atenção para a sobrevivência tem 
um lado positivo no sentido de a mulher se submeter a agressões do tratamento com maior facilidade.

\subsubsection{A sexualidade não alterada}

Embora as mulheres relatem, em sua maioria, que apresentaram algumas alterações na sexualidade, isso não significou que houve alterações no exercício da prática sexual.

"Eu não deixei de fazer sexo de jeito nenhum...e acho que ele melhorou, a gente consegue olhar um para o outro e dizer eu quero isso agora" (GF)

Os homens relatam que a sua sexualidade não foi alterada pelo fato de a mulher ter se submetido a uma cirurgia para a retirada de um tumor maligno ou uma mastectomia, o que alterou foi o tempo de espera até que as mulheres se recuperarem da cirurgia ou tratamento e se mostrassem dispostas para o ato sexual.

"A minha sexualidade não ficou afetada... A gente não teve problema no ato sexual". (GM)

"Para mim não houve diferença nenhuma, não dá diferença”.(GM)

"A minha sexualidade não foi alterada, não mudou nada na nossa relação".(GM)

"Do meu lado não mudou nada". (GM)

"A gente leva como pode levar. Eu estou a fim e vejo que ela não está a fim, eu não vou forçar a barra".(GM)

Fisicamente, não houve motivo para os homens apresentarem alterações da sua prática sexual, mas um deles afirma que houve modificações na quantidade de relações que eles tinham, devido ao estado da esposa. 
A dificuldade em aceitar o diagnóstico do câncer afetou psicologicamente um dos homens, levando-o a perceber alterações em sua sexualidade, mesmo sabendo que não haveria a retirada da mama de sua companheira.

"Não somos mais o que nós éramos. Eu acho que isso é de mim. Mudou muito, caiu muito, para mim caiu". (GM)

\subsection{6. $O$ desejo sexual}

Um dos fatores que influenciam no exercício da prática sexual é a vontade de estar com o outro, de sentir a sua pele e o desejo de compartilhar da intimidade do outro. Não é somente o ato sexual que permitirá essa aproximação, mas o contato pele a pele pode levar a uma intimidade tão grande e propiciar a consumação do mesmo.

Sabemos que não há regras gerais na sexualidade e, apesar de esta ser regulada por padrões culturais, cada casal durante o tempo em que convivem, fará uma construção de sua vida sexual, utilizando regras e práticas por eles estabelecidos. Assim, essa construção levará a uma aceitação do outro, valorizando suas qualidades e aceitando as falhas e carências mutuamente.

O desejo é um dos componentes para que o ato sexual se desencadeie, sendo influenciado por estímulos eróticos visuais, táteis e sonoros. E, dependendo do estado geral físico ou psicológico de um dos membros do casal, o ato sexual poderá ocorrer ou não.

Em nosso estudo, os homens relataram, em sua maioria, que não tiveram alteração do seu desejo sexual. 
"A nossa atração, o nosso magnetismo, nunca perdeu, nunca parou. Eu sempre tive muita atração por ela, e tenho até hoje, não mudou nada".(GM)

"O desejo não afetou nada em mim". (GM)

Um homem mencionou que durante o tratamento, ao ver sua esposa mal, teve alterações em seu desejo sexual.

"Durante a quimioterapia, o meu desejo diminuiu".(GM)

Somente um dos homens afirmou que seu desejo foi alterado em função da doença de sua esposa e ele estava relacionado à doença em si, visto que ela não foi mastectomizada.

"Se eu pensar no que ela passou, eu perco todo o desejo, já acaba tudo ali."(GM).

Apesar de todas as mulheres serem submetidas à quimioterapia e relatarem alguns efeitos colaterais como descritos anteriormente, obrigatoriamente isso não significou alteração no seu desejo sexual. Houve relatos de aumento de desejo durante a quimioterapia, mesmo percebendo o ressecamento vaginal. Essa mulher tinha uma necessidade maior de ser acariciada e estimulada sexualmente, fato que pouco conhecemos, como efeito colateral da quimioterapia.

"Uma coisa que eu percebi é que durante a quimioterapia, eu tinha mais vontade de ter relação sexual, meu desejo era maior. Eu sentia mais desejo, mas não tinha aquela fissuração de ter a relação porque eu estava ressecada. Só que a quimioterapia mexeu com o meu organismo, mas não fiquei sem aquela vontade de fazer sexo com penetração". (GF)

"Eu tive ressecamento, eu via que não dava. Eu até tinha desejo, mas não ficava aquela lubrificação certa".(GF)

As mulheres afirmaram que para nos relacionarmos com o outro, a gente tem que querer, esse é um ponto importante.

"Na relação a gente tem que entrar com vontade, sem vontade não vira nada e emburra o outro".(GF) 
Costa $(2004$, p. 6) relata que

a convivência íntima de um casal é influenciada pela sintonia do desejo. Às vezes, um não está a fim porque está cansado e o outro quer fazer sexo. Se essa situação ocorre de vez em quando é possível contornar. Quando os desencontros são raros, é fácil desculpar o companheiro. A ternura e a lembrança de momentos prazerosos podem substituir a necessidade sexual daquele momento.

\subsubsection{A prática sexual}

A construção da prática sexual não segue uma receita, mas alguns fatores foram descritos pelos casais como importantes para um caminhar juntos e que permitiram melhorar a vida sexual do casal.

Sabemos que questões da vida sexual têm sido abordadas pela mídia nas várias etapas da vida e não só os aspectos de iniciação sexual. Problemas relacionados a doenças, ao uso de medicamentos, a fatores psicológicos, o envelhecimento da população, à gravidez, às patologias sexuais, têm sido abertamente discutidas pelos veículos de comunicação, visto a sexualidade ser afetada indiretamente.

Devemos entender que a sexualidade de um casal vai ser influenciada por alguns fatores como a idade, a saúde física e psicológica e o relacionamento que o casal costumava ter.

Bozon (2004) mostra que a atividade sexual do casal segue uma rotina. No início do casamento, há maior preocupação com a construção do relacionamento do casal, a fidelidade é extremamente importante e o desejo sexual é alto. Na segunda fase, que corresponde à fase da formação da família, há uma diminuição das relações sexuais, mas os cônjuges normalmente estão satisfeitos com a sua vida sexual e, a terceira etapa, ocorre após alguns anos do casamento, quando o casal 
se estabiliza e o número de relações sexuais diminui, mas a rotina dentro do casamento permite um efeito tranqüilizador sobre os parceiros.

\subsubsection{O Reinício}

O reinício das relações sexuais se deu dentro da rotina de cada casal, sendo que, após a melhora do estado geral da mulher, a maioria relata que a vida sexual foi retornando vagarosamente, sendo que não havia cobranças e a troca de carícias foi acontecendo gradativamente, chegando ao ato sexual ou não, mas a aproximação física do casal ocorreu. A quimioterapia foi colocada como um fator inibidor da prática sexual.

Costa (2004) relata que em situações de estresse, quando há um familiar doente, as pessoas normalmente têm uma libido diminuída, ficam sem desejo de fazer sexo, sendo normal nesse período que o contato íntimo fique menos intenso.

"Umas três semanas depois a gente começou a fazer sexo".(GF)

“Havia carícias, mas eu deixei por conta dela”.(GM)

"Em torno de um mês, quando ela se sentiu melhor".(GM)

"Durante a quimioterapia, a gente tinha pouca relação. Mas depois é que terminou a quimioterapia é que a gente voltou a ter um relacionamento melhor".(GM)

Entretanto, foi a rotina do casal ou a aceitação da doença da esposa que determinou esse retorno, porque a construção subjetiva da doença se dá de forma individual e a prática sexual é realizada a dois. Então, houve a necessidade dos dois se aceitarem perante essa nova situação para retornarem a ter vida sexual.

"Eu me lembro que demorou bastante. A rotina do casal já é meio lenta e daí prolongou porque uma coisa e outra. Uma hora você não está bem, outra você está emburrada". (GF) 
"Ficamos mais de um ano sem ter relações. Voltamos, mas não é como era"(GM)

"A gente foi voltando a ter relações sexuais devagarinho, utilizando o lubrificante vaginal". (GF)

Importante relatar que em nosso estudo a mastectomia não foi um fator inibidor da volta da relação e, sim, a aceitação da doença câncer.

Sabemos que não existe um tempo certo para o reinício da atividade sexual e que esta volta vai depender de como é o entrosamento do casal. O importante é não deixar de conhecer e explorar o corpo no sentido de perceber as sensações e obter relaxamento e provocar a excitação. Se o casal consegue realizar essas atividades, provavelmente da próxima vez o corpo estará relaxado para carícias nos órgãos sexuais e a relação sexual poderá ocorrer (SEGAL, 1994).

Meyerowitz et al. (1999) relatam que mulheres que tiveram um câncer de mama apontam dificuldades em algumas áreas da sexualidade até três anos após o diagnóstico, mas poucos estudos relatam quais são essas dificuldades.

Um dos fatores que foi relatado como facilitador para o reinício das atividades sexuais, foi o diálogo.

O conversar sobre as preferências sexuais ou o modo de ser acariciado também foi colocado como um fator para melhorar a vida sexual. A preocupação em agradar o outro sexualmente fortaleceu vínculos, levando o casal a se expressar e a resolver seus problemas cotidianos.

"Nós sempre nos demos bem. Conversando não gosto disso, não gosto daquilo. Diálogo a gente sempre teve. Ele nunca fez comigo aquilo que eu não quisesse. Nós sempre conversamos muito, em parte de sexo, o que me agradava e o que desagradava e ele sempre foi preocupado em me satisfazer".(GF).

"Eu não invento desculpas para não transar e eu falo para ele: você não ia gostar porque hoje eu não estou com um pingo de vontade". (GF) 
Neste grupo, observamos que o diálogo foi um componente que fortaleceu a vida sexual e a que a intimidade que já existia favoreceu o retorno da vida sexual. A comunicação sobre o que se está sentindo, o que dá mais prazer e mesmo o não querer, são fatores que facilitam o relacionamento sexual.

"Durante a doença a gente conversava muito. Mas na área sexual não sei se ele tem vergonha, ele é meio caladão". (GF)

"Às vezes a gente conversava, mas cada um achava uma coisa e não batia as idéias, mas ele sempre se preocupou com o meu prazer. Eu nunca falei, mas ele sempre menciona o que agrada mais ou não".(GF)

"Não, eu sempre fui quietão, a gente sempre se entendeu".(GM)

"Não precisa conversar, a gente se dá bem e eu tenho vergonha".(GM)

Para alguns casais, esse também foi o momento de se conversar bastante, não obrigatoriamente na área da sexualidade, porque eles tinham dificuldades de falar sobre essa área, mas relatam que mesmo assim se entendem.

Segal (1994, p. 93) relata que

muitos casais não conversam sobre sexo, mas que após um tratamento de câncer isso deverá mudar, uma vez que a boa comunicação será essencial para a vida sexual do casal. Procure mostrar por palavras, ou mesmo conduzindo as carícias do seu parceiro o que mais Ihe agrada. Se o câncer alterou demais a vagina, talvez a penetração não seja possível; nesse caso o casal poderá experimentar outros aspectos da vida sexual, pois não há razão para não se tocar e acariciar.

Outro fator facilitador a volta das atividades sexuais foi o casal enxergar que estão envelhecendo juntos e que esse é um fator que influencia na sexualidade.

O envelhecer é um processo com o qual convivemos desde o momento em que nascemos, mas geralmente só tomamos conhecimento dele quando somos adultos. 
Com a melhora das condições de saneamento básico, assistência à saúde e prevenção de doenças, a população mundial está vivendo mais e nos confrontamos com novos problemas sociais e de relacionamento.

Até poucos anos atrás, uma mulher de 40 anos era tida como coroa e, quando fazia a menopausa, era considerada velha e acreditava-se que, por não ser mais reprodutiva, sua vida sexual estava encerrada. Com o aumento da expectativa de vida da população, conhecemos que essa não era uma verdade e que a mulher pós-menopausa, mesmo com um déficit hormonal, só deixa de ter relações sexuais se ela não tiver um companheiro ou se este apresentar problemas de saúde que comprometam a sua prática. Com casais que sempre tiveram um bom relacionamento sexual, mesmo que haja algum fator que impeça a penetração vaginal, vão haver carícias e momentos de intimidade.

Este grupo de estudo acredita que estão envelhecendo juntos, mas que não dá para perceber esse envelhecer. Outros afirmam que percebem as mudanças que os anos vão trazendo, mas que isso não impede o relacionamento sexual.

"O tempo inexiste, ele passa tão rápido que você não percebe".(GM)

"Você faz menos, mas faz a mesma coisa, você perde fisicamente". (GM)

"Eu estou mais velha e ele também. A gente não é mais como vinte anos atrás... A gente vai passando as fases da vida, chega uma fase que foi muito elétrica, outra que já foi mais calma e estamos naquela que tem o seu tempo, mas é tudo, o dia que faz, faz bem feito". (GF)

"Eu já senti que está mudando e ele falou: Você sentiu que já está mudando? Eu falei: senti".(GF)

"Eu acho que nós estamos envelhecendo juntos, só que ele não aceita muito... O sexo é importante para o casal, mas não é tudo".(GF)

"A gente está em um momento bom de nossas vidas, estamos mais companheiros. Eu acho que o caminho é esse, de envelhecer junto". (GF) 
Interessante que nem os homens nem as mulheres associaram o envelhecer ao câncer de mama e, sim, que este é um fator que influencia na vida sexual do casal.

Hoje sabemos que homens e mulheres após os 40 anos sofrem alterações na fisiologia do ato sexual. Os homens têm uma diminuição da quantidade do esperma, da pressão com que esse é ejaculado e a ereção desaparece logo após o orgasmo e, às vezes, a ereção peniana necessita de estímulo direto no órgão genital, visto que há a diminuição de fornecimento de oxigênio devido à hipertensão, ao diabetes, o que leva à redução do óxido cítrico que mantém a ereção (ROSENTHAL, 2004).

$\mathrm{Na}$ mulher, além dos aspectos culturais que associam a menopausa com a velhice, é o período em que começa a ocorrer a diminuição gradativa do estrógeno, culminado com a menopausa. Essa redução de estrógeno após os 40 anos provoca o adelgaçamento das paredes vaginais, a diminuição da libido, o encurtamento da vagina e o decréscimo da lubrificação vaginal, o que pode tornar a relação sexual desconfortável (ROSENTHAL, 2004).

Neste grupo de estudo que vivenciou um câncer de mama, alguns fatores inibidores como a falta de desejo, a diminuição da lubrificação vaginal durante a quimioterapia, a ausência da mama, a dor, dificuldade de movimentação do braço ocorreram, não foram motivos suficientes, para impedir que o relacionamento sexual retornasse.

\subsubsection{Posições e Adaptações}

O retorno à prática sexual trouxe ao mesmo tempo novas preocupações e algumas mudanças tiveram que ser repensadas e adaptadas pelo casal. Essas 
adaptações foram mais relacionadas ao cuidado com o braço e com o lado operado, para diminuir o desconforto e a dor do que mudanças nas posições e nas práticas sexuais adotadas. Os homens apresentam essa preocupação.

"A gente faz a posição mais confortável para ela. Quem define a posição é ela".(GM)

"A gente procura uma posição que não machuque o braço". (GM)

"Não foi necessário, não houve mudanças após a cirurgia. Não, a gente continua sempre a mesma coisa".(GM)

As mulheres determinaram que a cirurgia as obrigou à mudança do lado de dormir por causa do desconforto da mama comprimida e que isso interferiu no hábito de casal se aconchegar diariamente, influenciado nas carícias que eram praticadas independentemente do ato sexual, o que necessitou uma adaptação.

"Deixar de deitar no ombro dele, do lado esquerdo fez muita falta. Nós tentamos mudar a posição de dormir, mas não dá certo, não tem a mesma comodidade".(GF)

A maioria dos casais relatou que tem como prática sexual de preferência a vaginal, e que não houve mudança com o câncer de mama, dado diferente de Anllo (2000) que refere que durante a quimioterapia alguns casais preferiram adotar o sexo oral como uma outra opção de prazer, relacionados como uma alternativa ao ressecamento vaginal ou à dispareunia. Neste grupo de estudo, o uso de lubrificantes, de fitas pornográficas e de condom lubrificado surgiram como alternativas para aumentar o desejo sexual ou diminuir o desconforto na relação sexual.

Horden (2000) relata que a enfermagem deve orientar as mulheres sobre o conforto de se utilizar uma lubrificação extra-vaginal nas relações sexuais durante o tratamento de câncer de mama e que esses lubrificantes não devem ser coloridos, perfumados e, sim, à base de água e livres de estrógeno. 
"A gente usa um produto de lubrificação. A gente procura fortalecer a nossa relação. A gente toma mais cuidado com o braço. Não, não teve nada que mudou por causa da cirurgia" (GM)

"Eu estava sempre acarinhando. A gente assistia fita pornô". (GM)

"Eu pedia para ele usar camisinha porque ela tem lubrificante". (GF)

Os casais foram procurando formas de estimular o relacionamento sexual, seja utilizando-se lubrificantes para evitar o desconforto durante o ato, seja se excitando com o estímulo visual de fitas pornográficas, não se importando se obrigatoriamente o ato sexual iria acontecer.

“Eu sei, não é fácil, passar o que ela passou e estar disposta a fazer sexo...Eu sempre estava a acarinhando, abraçando-a".(GM)

"É um novo corpo, não é uma pessoa diferente, mas é um novo corpo".(GM)

Reconhecer nesse novo corpo aquela outra mulher que ela já conhecia foi o mais difícil para esse homem, mas ele percebe que isso é necessário para voltar a um bom relacionamento sexual e conjugal.

Conhecer o tempo do outro, pensar na situação que está ocorrendo e buscar um novo caminho a percorrer foi percebido como uma das alternativas de enfrentamento dos homens.

Em relação à prática sexual e às posições utilizadas os casais relataram que não houve mudanças. A posição sexual mais adotada pelos casais é o homem por cima da mulher.

"Não mudaram, eu sempre por cima".(GM)

"É, voltei a utilizar essa posição (a mulher por cima) porque não faz pressão na mama". (GF)

"É uma posição boa porque o homem não faz pressão na mama". (GF)

"Depois de um tempo, voltamos. Depois que já tinha uma movimentação melhor, que já dava para movimentar melhor, voltamos sem problemas". (GF) 
"Algumas vezes, não atrapalhou em nada porque eu só tirei um lado da mama". (GF)

Os padrões culturais determinam que o homem é responsável iniciativa sexual e a posição mais adotada é o homem por cima da mulher durante o ato sexual. Estudiosos relatam que a posição superior do homem no ato sexual se justificava por eles governarem a casa e a mulher. Embora a posição tradicional ainda seja muito utilizada, a posição da mulher por cima vem sendo mais comum entre as mulheres mais jovens e que buscam o prazer, visto haver uma estimulação mais direta do clitóris (BOZON, 2004; YALON, 2002).

Neste grupo, a posição mais adotada é o homem por cima, entretanto alguns casais declaram que a doença da esposa os levou a procurarem outras posições e alguns casais afirmaram que utilizavam a posição da mulher por cima porque ela diminui a pressão no braço.

"A questão de como vai segurar, não apertar, não fazer força na
região da mama no abraçar e apertar. Então a gente acabou se
adaptando de uma tal forma de tomar cuidado, que não atrapalhou,
mas acrescentou um cuidado. No entanto as adaptações entraram na
rotina e eu sempre tive uma capacidade de adaptação muito grande e
meu marido também, por isso a gente não teve problemas". (GF)

"Às vezes a gente falava essa posição é melhor, dá para ficar bem, então dava para falar deste jeito é melhor, não incomoda em nada". (GF)

Um casal relata que, pelo fato de a mulher ter parado de trabalhar para realizar o tratamento, houve uma mudança na rotina dentro de casa e que isto refletiu na melhora da vida sexual do casal.

"A gente faz as mesmas coisas que a gente fazia antes. Está melhor agora. Ele reclamava muito que eu não dava atenção para ele, com o que ele tinha que falar. A vida estava correndo e eu não estava vendo" (GF)

A dupla jornada de trabalho feminino tem sido um dos fatores de desgaste da saúde conjugal da mulher, pois, além das atividades fora do lar, existem as tarefas 
domésticas, os filhos e a administração do lar, que são tidos como atividades femininas. Ao ir para o leito conjugal, ela está cansada e muitas vezes evita o relacionamento sexual ou o faz como obrigação marital.

Observamos que nesse grupo de estudo houve um ajustamento do casal quanto ao relacionamento sexual e que, devagar, os cônjuges foram determinando o que era mais satisfatório.

\subsubsection{Nudez e queda dos cabelos}

Alguns trabalhos sobre a mulher mastectomizada colocam que esta tem dificuldade de ficar nua perante seu companheiro (BIFFI, 1998; CLAPIS, 1996; SILVA; MAMEDE, 1998). Neste grupo, todas as mulheres relataram que ficam nuas perante o companheiro independentemente do tipo de cirurgia, visto isso ser uma prática já adotada na rotina do casal.

"Eu tomo banho, se estiver pelada tudo bem, não tem problema".(GF)

"Mesmo após a cirurgia eu continuo a ficar nua em frente ao meu marido". (GF)

"Eu não tenho vergonha de ficar sem roupa perto dele, de jeito nenhum".(GF)

"Eu tomo banho junto com ele, neste ponto não mudamos nada".(GF)

"Eu não me envergonho não, troco de roupa na frente". (GF)

"Eu nunca pensei, não vou tirar o sutiã porque ele vai ver. Eu tirava, me trocava, tomava banho junto, sem essa preocupação de que ele vai ver. Eu vejo que ele não está muito satisfeito com o que ele está vendo".(GF)

"Não tive esse problema não, a gente toma banho junto, a gente se troca, fica sem roupa junto e a gente não tem nenhuma vergonha".(GF)

"Eu fico nua perto do meu marido, porque eu acho que não tirei a mama, só ficou uma marca na mama". (GF) 
Yalon (2002) relata que, a partir de 1900, a nudez já era descrita como uma prática comum entre os casais, principalmente na hora do sexo, fato esse que, com a evolução da sociedade, se tornou um ato corriqueiro.

Os homens pouco abordaram sobre a nudez, mas não negaram que ela existia. Um dos maridos coloca que a mulher não mudou a rotina do casal por ter realizado a mastectomia. Que a retirada da mama sempre foi imposta a ele porque a mulher não a escondia, dado diverso de outros trabalhos que relatam que a mulher mastectomizada evita a nudez perante o marido (CLAPIS, 1996; SILVA; MAMEDE, 1998).

"Ela sempre me impôs essa situação nova, então isso não aconteceu comigo. O que ela oferecia era isso: o prato é esse, não dava para fugir".(GM)

"Não, a gente toma banho junto. Ela veio da cirurgia eu dava banho nela, eu lavava. Esse problema a gente não teve". (GM)

"Ficar nu? A gente fica".(GM)

Sabemos que o corpo nas últimas décadas foi ficando mais exposto, as roupas mais curtas, os decotes mais pronunciados e, no relacionamento sexual, a nudez é estimulada como um fator para se descobrir as zonas erógenas e pode ser influenciada pelo relacionamento antes da cirurgia, da idade dos cônjuges, do tipo de cirurgia, hábitos, etc. Como esses casais já tinham esse hábito de ficarem nus, após a cirurgia, mesmo nas mulheres mastectomizadas, ele persistiu, demonstrando que as mulheres impuseram essa situação e os homens a aceitaram.

O dado de maior dificuldade de aceitação foi a queda dos cabelos decorrentes da quimioterapia, tanto por homens como pelas mulheres. Ambos relatam que foram informados desse efeito colateral da quimioterapia, mas que, quando ele ocorreu, descobriram que não estavam preparados para o fato.

"O dia que eu percebi que o cabelo estava caindo, eu entrei em pânico e eu chorei. Eu achei que não ia acontecer. Eu pensava, às vezes ele 
não vai cair. Então o dia que eu vi ele desabou, porque ele desaba de uma vez, é impressionante, sabe eu apavorei. O meu cabelo já nasceu. Ele nasceu cacheadinho e está mais enrolado. Agora eu estou contente e feliz. Eu acho ele tão lindo agora". (GF)

"Quando o meu cabelo caiu, eu passava o pente e caia aquele monte. Mas depois ele começou a crescer, só que um cabelo avermelhado, seco e começou a branquear. é por causa da quimio, viu, é da quimio, começou a branquear".(GF)

"Ele (o cabelo) caiu. Eu não cheguei a cortar, mas virou uma farofa e eu tive que mandar cortar, na próxima lavada caiu tudo. O pêlo do corpo não caiu tudo não, nem da vagina e do braço. Os cílios e a sobrancelha caíram um pouco".(GF)

Sabemos que um dos efeitos colaterais da quimioterapia é a alopecia e que o impacto na auto-imagem da mulher é negativo, pois ele é um efeito visível, apesar de no câncer de mama a maior ênfase ser a mama. No entanto, neste estudo a perda dos cabelos foi colocada com grande pesar pelas mulheres. Acreditamos que o fator religioso para algumas dessas mulheres tenha sido fundamental visto que para elas o cabelo comprido é um elemento representativo da feminilidade perante Deus.

Somente dois homens levantaram a questão dos pêlos do corpo terem caído, dizendo que isso não mudou em nada a atração que eles tinham pela esposa.

"Não, para mim é como se nada tivesse acontecido e ela ainda brinca: como? Eu não tenho um fio de cabelo no meu corpo. Tudo bem, eu não sinto diferença por conta disso, eu continuo com essa atração, então talvez o fato de eu já ter essa atração forte por ela, tenha facilitado as coisas, eu imagino. Eu não sei como seria se eu não tivesse (atração). Mas, eu agradeço por eu ter, eu acho que ficou mais fácil. Ficou mais fácil, não mudou, é como se não tivesse acontecido nada".(GM)

"A gente fica triste, desesperado, falta alguma coisinha porque ela tem um cabelo muito bonito, mas Deus quis assim. O meu desejo não afetou em nada, o meu amor que eu sinto por ela não afetou em nada, ele é grande o bastante".(GM) 
Os homens afirmaram que a atração física e o amor são fatores que contribuíram para passar esse período de alopecia da mulher, mas não escondem que eles também ficaram abalados com esse fato.

\subsubsection{O espaço físico}

O espaço físico é um dos fatores que podem facilitar ou impedir a prática sexual, principalmente quando a família tem filhos. Esse espaço deve ser construído a dois e as formas serão diferentes, mas estará relacionado à área física e a como o casal concebe o seu espaço.

"Como moramos só nós dois, pode ser de manhã, à noite, durante o dia, não tem esse negócio que só aquela horinha, só de noite".(GF)

"Meus filhos interferem muito. Eu não posso fechar a porta do meu quarto que eles vêm bater e perguntar porque eu estou trancando a porta".(GF)

Para esse casal, os filhos acham que os pais não têm direito de namorar e acabam interferindo no relacionamento do casal. Provavelmente esse casal não construiu o seu espaço de autoridade com os filhos nem o espaço físico para se amarem. Sabemos que a construção sexual do casal se faz durante o relacionamento e que horários e locais onde o casal possa ficar mais à vontade são de extrema importância para essa construção.

"Ele chegava de manhã, os filhos dormindo, a casa tranqüila e a gente acabava rolando mesmo". (GF)

"Procuramos mudar os horários porque à noite a gente estava muito cansado. Começamos a fazer de manhã, o que eu detestava. É chato ficar trancado no quarto quando um transita pra lá, outro para cá, é filho, é neto que chega".(GF)

Costa $(2004$, p. 73$)$ relata que 
as pessoas acima de 50 anos de idade, o corpo parece estar mais preparado para o sexo em determinado período do dia: pela manhã. Em função do estresse acumulado, chegam ao final do dia mais cansadas e preferem ter relações matinais - os homens aproveitam as ereções espontâneas, apesar de que o desejo nem sempre é intenso. Já as pessoas mais jovens, essas estão sempre prontas: não tem horário predeterminado. Dependem mais das oportunidades e do clima criado entre o casal.

\subsubsection{A Falta de Informação}

Perante a doença, alguns casais afirmam que a desinformação na área da sexualidade foi uma constante, visto que os profissionais da área da saúde não ofereceram essa informação espontaneamente a nenhum dos casais.

Vários estudos sobre mulheres com câncer de mama demonstram que as informações a elas e à família é restrita a resolver o tumor e que os efeitos colaterais informados são os mais comuns como a náusea na quimioterapia e a queimadura na radioterapia. Orientações sobre a sexualidade, efeitos colaterais no sistema reprodutor, do tratamento coadjuvante não são fornecidos na rotina diária e só surgem se os profissionais forem questionados (HORDEN, 2000; MEYEROWITZ et al, 1999).

Falamos muito da importância da orientação, mas muitas vezes esquecemos que os efeitos colaterais podem aumentar o estresse que a mulher já está vivenciando e que o simples relato de que a quimioterapia pode levar a alterações no ciclo menstrual já reduziria essa ansiedade.

"Não me falaram que ia parar a menstruação. Não me orientaram e eu fiquei preocupada".(GF)

"O médico nunca tocou no assunto sexualidade, mas a gente tem sim, tem muita dúvida. Nesse negócio de sexualidade nenhum nunca tocou no assunto, a não ser que de agora para frente eles vão falar, mas até agora eles não falaram nada".(GF) 
Os homens relatam que buscaram alguma informação com seus médicos, mas que o enfoque é a doença e que a fala é extremamente técnica. A maioria dos homens ficou sem informações ou por não terem acesso aos médicos ou por vergonha de perguntar.

\begin{abstract}
Não, eu não recebi. O médico fala sobre a profissão dele, nós vamos tirar daqui e vamos colocar lá e nunca se preocupou em dar nenhuma orientação sobre esse assunto específico de relacionamento, de secura, que você tem que usar um lubrificante ou não usar, não tem orientação" (GM).
\end{abstract}

"Nessa área (sexual) eu sempre tive vontade de perguntar".(GM)

Algumas mulheres disseram que o médico explicou algumas coisas porque foram questionados por elas, mas que acham que eles também ficam limitados.

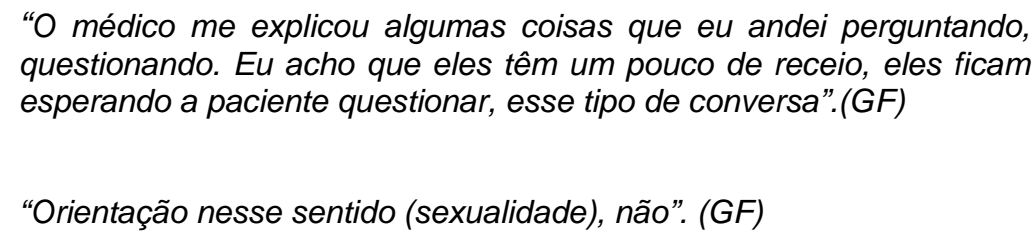
questionando. Eu acho que eles têm um pouco de receio, eles ficam esperando a paciente questionar, esse tipo de conversa".(GF)

"Orientação nesse sentido (sexualidade), não". (GF)

Pitceathly; Maguire (2003) relatam que companheiros e pacientes que receberam informações de acordo com suas expectativas estavam mais bem ajustados e mais satisfeitos com o atendimento.

As mulheres, por participarem do grupo de auto-ajuda no REMA, relatam que foi neste espaço que tiraram algumas dúvidas, fato confirmado por um dos homens que relata que era neste espaço que o casal tirava as dúvidas.

"Às vezes a gente se envergonha de perguntar alguma coisa. O que eu tive que perguntar foi para vocês no REMA, quando a gente tinha uma intimidade maior". (GF)

"As dúvidas que a gente tinha, ela tirava lá no REMA, ou com uma amiga que é enfermeira".(GM) 
Uma das mulheres diz que, apesar de o grupo ser o local de maior informação na área da sexualidade, ele tem como limitação ser muito grande, heterogêneo e ter homens, o que no seu caso tira a liberdade.

"A gente ficava pensando o que pode e o que não pode. Além do grupo ser grande, às vezes tem homem". (GF)

O REMA, além do atendimento individual, realiza exercícios em grupo e possui um grupo de ajuda que funciona três vezes por semana. Esse espaço tem como finalidade que as mulheres que tiveram um câncer de mama possam colocar suas dúvidas e receios, compartilhar experiências vividas. Tem como vantagem tratar várias pessoas ao mesmo tempo e as participantes verificarem que seus sentimentos não são únicos.

O fator desinformação sobre a doença e a sexualidade neste grupo de estudo foi marcante, pois, ao final de toda entrevista, tanto os homens como as mulheres realizaram muitas perguntas. As mulheres perguntavam muito sobre as alterações do seu corpo, independentemente de serem mastectomizadas ou não, no sentido de saber até que ponto ele voltaria a ser o que era. $\mathrm{Na}$ área da sexualidade, a maior preocupação era o ressecamento, visto que no momento da entrevista somente uma mulher se queixou de falta de desejo. Nos homens, as perguntas estavam relacionadas com a recidiva do câncer, se o ressecamento diminuiria e sobre carícias na mama operada durante o ato sexual.

Wilmoth (2001) relata que as enfermeiras estão em uma posição favorável para ter uma influência positiva no ajuste da mulher que teve um câncer de mama na área da sexualidade, visto que elas são hábeis na comunicação, têm conhecimento sobre o tema e essa atividade pode ser incluída durante os cuidados prestados. 
Neste grupo, o fato de ter amigos ou parentes enfermeiros facilitou o acesso a orientações sobre dúvidas que foram aparecendo, tanto sobre o tratamento como sobre a vida sexual.

"Mas quando a gente tem problema a gente conversa, a gente vai junto, mas acho que por ela ter um nível cultural bom e por a gente ter vários amigos enfermeiros, isso facilitou bastante".(GM)

Ao conversarmos sobre a necessidade de informação, perguntamos qual seria a postura dos homens se houvesse um grupo para eles discutirem suas dúvidas. De um modo geral, tanto homens como as mulheres afirmaram que seria difícil a participação dos mesmos por vários motivos, como o trabalho, o horário, homem não gostar de falar sobre si, entre outros.

Grupos de homens que discutem sobre o seu papel na sociedade já existem no Reino Unido, na Alemanha, no Canadá e vêm crescendo cada vez mais. A estrutura desses grupos segue algumas diretrizes gerais: ninguém é forçado a falar, só fala quem quiser, deve-se falar o que sente e não ficar teorizando e procura-se ouvir (BIDDULPH, 2003). No Brasil, grupos têm sido criados no sentido de auxiliar os familiares, quando existe alguma patologia, principalmente em crianças portadoras de Síndrome de Down, autismo ou que apresentam patologias na área comportamental.

As mulheres afirmaram que é importante ter um grupo de homens que vivenciam o câncer de mama, elas só não sabem afirmar se eles iriam participar.

"Eu acho que é muito difícil porque homem parece que eles são muito atirados, mas eu acho que são mais tímidos que as mulheres. As dúvidas que eles têm eles perguntam para a mulher dele mesmo, eu não pergunto para ninguém".(GF)

"Eu acho que o meu marido não iria, mesmo sendo informativo". (GF)

"Não sei se eles participariam porque homem é um pouco duro, meio difícil, mas que seria bom, seria". (GF) 
"Uma grande maioria não iria porque homem é mais reservado, eles não são tão abertos quanto a gente". (GF)

"Eu acho que ajudaria porque tem muitos homens que porque a mulher retirou a mama ele vai atrás de outra".(GF)

"Eu acho difícil os homens quererem ir, teria que pegar no laço. No entanto, eu acho que é como o REMA, um vai contando para o outro e depois vai tendo uma freqüência maior. Eu acho que seria superinteressante ter alguma coisa em que o companheiro pudesse receber informações de uma maneira geral. Não sei se eles seriam muito constantes, mas após o diagnóstico tem que saber como acompanhar". (GF)

"Com o meu marido eu acho que funcionaria porque ele quer aprender, eu acho que para ele funcionaria. Agora os outros homens eu não sei, porque muitos não querem saber nem da entrevista"(GF).

As mulheres acham pouco provável que os homens queiram se sentar para discutir as dúvidas que eles têm, porque culturalmente o homem não expõe seus sentimentos nem falam de suas dúvidas em público. No entanto, todas afirmaram que seria importante ter esse espaço para que o homem tirasse suas dúvidas.

Os homens também acham difícil a participação deles em grupo para discutir as suas dificuldades, mas afirmaram que seria bom para eles e para as mulheres.

"Pode até ser necessário, difícil é achar quem vá porque o homem não tem espírito familiar".(GM)

"Eu acho difícil. Eu acho difícil, pegar um homem sozinho já é duro. Se ele (o homem) ficar seguro que não vai responder muita coisa, talvez ele vá. Para a mulher seria bom se o homem tivesse mais informação".(GM)

"Um grupo de homens? Acho que funciona sim. Eu iria porque eu gosto de aprender". (GM)

"Devia existir um REMA para os homens, não fisioterapia, mas com o psicólogo, trabalhar a cabeça dos maridos. Tem muitos maridos que levam as mulheres lá no REMA, Hospital das Clínicas e fica lá fora, vai à cidade, preenche o espaço. Esse espaço deveria ser aproveitado".(GM) 
Apresentação e análise dos dados

A fala dos casais reproduz o padrão cultural esperado, ou seja, cabe à mulher buscar informação, participar de grupos de ajuda, enquanto os homens, mesmo precisando, apresentam restrições sobre a sua participação efetiva, porque culturalmente do homem é esperado que não exponha seus sentimentos. Por outro lado, atividades em grupo são tidas como uma coisa feminina, porque grupos estão ligados à expressão de sentimentos, utilizando-se da fala e da expressão corporal.

Os homens, desde crianças, não são estimulados a falarem de si e, talvez por isso, tenham dificuldades de pertencer a grupos especiais. 
5. A CATEGORIA CENTRAL: A SEXUALIDADE DOS CASAIS QUE VIVENCIARAM O CÂNCER DE MAMA: quebrando mitos

Após a análise dos dados sobre as questões relacionadas à sexualidade de casais que vivenciaram o câncer de mama, foi possível criar o seguinte diagrama (diagrama 3). 
Diagrama 3 - Sexualidade dos cônjuges que vivenciaram o câncer de mama: quebrando mitos

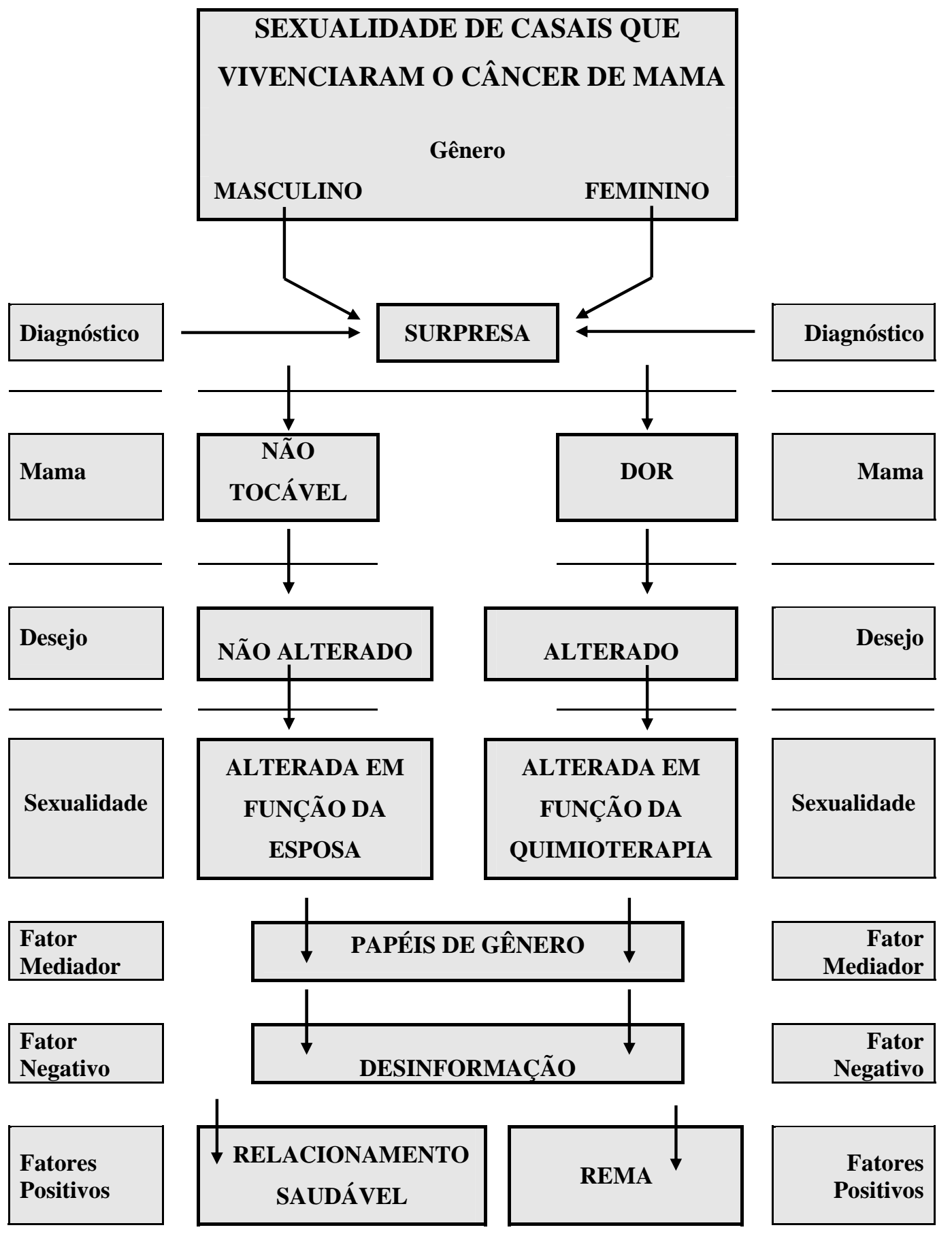




\section{SEXUALIDADE DOS CÔNJUGES QUE VIVENCIARAM O CÂNCER DE MAMA:}

\section{quebrando mitos}

Relações de gênero são uma construção cultural e social e, como tal, representam um, processo contínuo e descontínuo da produção dos lugares de poderes do homem e da mulher em cada cultura e sociedade (OLIVEIRA, 1997, p. 4).

Assim, essas relações são construídas e desconstruídas, não de uma forma institucional, mas de uma forma particular e individualizada, permitindo novas construções na sociedade.

O estudo sobre a sexualidade neste grupo de casais que vivenciaram o câncer de mama trouxe-nos novos conhecimentos e a desmitificação de alguns conceitos, que estão engendrados na nossa prática profissional ao lidarmos com a mulher que passou pela experiência do câncer.

Um dos primeiros mitos está relacionado ao gênero masculino do qual é esperado um comportamento indiferente frente à situação de um diagnóstico de câncer de mama, quando é dito que ele foge da situação, abandona ou não se preocupa com a companheira.

Neste estudo, não somente os membros do gênero masculino participaram do tratamento da companheira, como também procuraram estar ao lado delas, enfrentando as alterações e dificuldades surgidas nesse período. Além disso, eles criticaram ferozmente homens que têm a atitude de abandonar a companheira por esta estar doente.

Observamos que os membros do gênero masculino não participaram mais ativamente do tratamento da mulher, porque a mesma o dispensava dessa atividade, 
dizendo que era melhor ele ir trabalhar ou que era uma perda de tempo eles ficarem acompanhando-a durante a quimioterapia, por exemplo.

O segundo mito refere que a atividade sexual fica prejudicada de ambos os gêneros e que, após o câncer de mama, o casal não retorna o relacionamento sexual. O estudo demonstrou que, na maioria dos homens, o desejo sexual não foi alterado pela doença da esposa. Nas mulheres, algumas tiveram a libido diminuída, principalmente durante a quimioterapia, período em que ocorre uma série de alterações na fisiologia da mulher, como ressecamento vaginal e menopausa precoce. Entretanto, passados alguns dias após a aplicação da dose mensal, o retorno ao relacionamento sexual se dava espontaneamente.

Nessa fase, da quimioterapia, o casal utilizou de estratégias de enfrentamento, como o uso de lubrificantes vaginal, condom, fitas pornográficas ou mudanças de comportamento, como, por exemplo, esperar essas alterações melhorarem, para retornar às atividades sexuais.

O terceiro mito é que o casal, após um câncer de mama, não retorna as suas atividades sexuais. O mais importante é que os casais não somente retornam a essa atividade como fazem uma reconstrução no relacionamento, procurando respeitar um ao outro e adaptar posições durante o relacionamento, de modo que não haja desconforto para a mulher e que o braço do lado operado não seja comprimido.

O quarto mito é que as mulheres que são submetidas à mastectomia não ficam nuas perante seus companheiros. Neste grupo de estudo, mesmo as mulheres que não fizeram reconstrução mamária têm o hábito de ficarem nuas perante seus companheiros, porque esta já era uma prática do casal, anterior à doença. 
Os casais relataram que houve dificuldades de se aceitar esse novo corpo sem a mama ou com a reconstrução mamária, mas que essa é uma realidade que teve que ser enfrentada.

O mais importante é que os casais mostraram que o conviver com cumplicidade é um fator que facilita as adaptações quando elas se fizeram necessárias.

O câncer de mama trouxe modificações em suas vidas e a reconstrução se fez em vários aspectos do cotidiano, e não somente na sexualidade. As mudanças que ocorreram se deram em decorrência de diferentes naturezas para cada gênero. O casal busca um equilíbrio de forma para satisfazer a ambos nesta relação, revelando que os padrões culturais sobre a sexualidade masculina e feminina e, em especial, sobre a atividade sexual também vêm sofrendo alterações ao longo do tempo.

Tanto os homens como as mulheres relataram a importância da mama no relacionamento sexual, mas não a consideram imprescindível para seu exercício.

A sexualidade masculina centra-se nos órgãos genitais e no relacionamento sexual. Os homens dão mais ênfase à genitália do que às carícias. Esse fato pode explicar porque a mama, sendo um órgão erótico, por estar longe da genitália, levaos a conviver com a mama operada e sua mutilação sem interferência no ato sexual.

O desejo sexual por suas companheiras não ficou alterado pela doença, no entanto a sexualidade deles esteve alterada em função dos efeitos colaterais que a companheira apresentou durante o tratamento, influenciando no número de relações sexuais que o casal mantinha.

"a gente percebe assim que em termos de quantidade de relações, e tudo, a gente caímos em uma quantidade muito grande".(GM) 
Acreditamos que as questões de identidade de gênero permearam o modo como eles trataram suas esposas e que a falta de informação a eles foi um fator importante no que se relaciona a entender melhor o que estava acontecendo com suas mulheres.

Em nossa sociedade, as questões de prevenção e saúde ainda são mais do gênero feminino. Os homens manifestaram interesse em saber o que estava acontecendo com suas companheiras, mas se contentavam com as informações transmitidas por elas.

Os homens perceberem tanto as modificações físicas no corpo de suas companheiras como as psicológicas, mas não realizaram o movimento de ir buscar informações com a Equipe de Saúde sobre essas alterações por eles percebidas, contentando-se em manter silêncio sobre o que percebiam ou comentando com a própria companheira.

A desinformação entre os homens foi grande, independentemente do grau de escolaridade e do local em que ocorreu a assistência, visto que mesmo os casais que possuíam planos de saúde, em que o acesso à equipe de saúde é maior não houve informações acerca do enfrentamento das alterações corporais que ocorrem com a doença, em especial na área da sexualidade.

“Não, não. O que eu sabia, é o que ela me contava. Nunca me passou pela cabeça de eu ir. A não ser que ela falasse: vamos comigo! Eu largava tudo o que tinha para fazer e ia. Ela é uma mulher que nunca dependeu de mim, eu é que dependo dela".(GM)

Durante a entrevista, alguns mantiveram uma característica do masculino, sendo receptivos ao estudo, mas mantendo-se reservados acerca de certos acontecimentos que ocorreram com eles, como a perda do emprego, que acarretou em mudança do cotidiano familiar, a dificuldade de ereção que levou ao uso de medicamento orais anti-impotência e o abandono da mulher no momento do 
nascimento dos filhos. No entanto, as mulheres expuseram essas passagens dos fatos sem recriminá-los e como algo que acontece na vida de algumas pessoas que vivenciam um relacionamento a dois.

Entretanto, a maioria, em algum momento, aproveitou o encontro com a pesquisadora, durante a entrevista, para refletir e apresentar as suas angústias e medos sem constrangimento, utilizando esse momento para tirar suas dúvidas sobre a doença e o relacionamento sexual do casal.

Concordamos com Schraiber; Gomes; Couto (2005) que relatam que os estudos de gênero devem incluir o homem, porque o ganho ocorrerá também na saúde feminina, principalmente, em temas em que se consegue a participação masculina, como em casais em que a mulher enfrenta um câncer de mama. 


\section{CONSIDERAÇÕES FINAIS}




\section{CONSIDERAÇÕES FINAIS}

Ao iniciar esse estudo não imaginávamos o caminho que iríamos percorrer, visto que o que conhecemos sobre a sexualidade da mulher que teve um câncer de mama estava relacionado à auto-imagem alterada pela mastectomia.

Compreender esse fenômeno, à luz do discurso dos casais é fundamental, se quisermos ajudar essas mulheres que enfrentam o câncer de mama, pois indiretamente essa situação afeta seus companheiros.

Percebemos que há uma grande dificuldade em incluir o gênero masculino em pesquisas, visto que poucos demonstraram interesse em participar do estudo, não entendendo como a sua participação (deles) poderia ajudar no tratamento da companheira.

Identificamos que sexualidade entre os casais estudados foi construída desde o momento em que eles optaram por ficarem juntos. Como já havia uma construção no relacionamento a dois, mesmo com o diagnóstico de câncer, foi mais fácil a adaptação à nova situação e, conseqüentemente, conseguiram lidar com as alterações físicas e psicológicas que surgiram.

Neste grupo de estudo, verificamos que houve alteração do desejo sexual nas mulheres em decorrência das alterações físicas relacionadas ao tratamento, principalmente durante a quimioterapia e, entre os homens, o desejo não foi alterado, mas o relacionamento sofreu modificações, devido à resposta sexual das mulheres estar diminuída. 
Foi possível, entretanto, observar que, para os casais que apresentavam dificuldades no relacionamento conjugal, o diagnóstico do câncer os aproximou, embora não tenha interferido no relacionamento sexual.

O casal que apresentava alterações no relacionamento sexual, anterior à doença, apontou para o fato de que o homem é quem apresentava uma disfunção sexual e ele sentia dificuldade de procurar ajuda porque tem vergonha de se expor. Este ressalta que a esposa está ativa sexualmente e que seu problema nada tem a ver com o diagnóstico de câncer de mama.

O homem que referiu uma diminuição do desejo sexual, devido aos mitos do câncer, foi orientado pela pesquisadora, no sentido da desmitificação da doença.

Os casais relataram que as alterações marcantes foram durante a quimioterapia, visto que esse tratamento levou a desarranjos gastro-intestinais, desânimo, prostração, ressecamento vaginal, mudança no ciclo menstrual, diminuição da libido e uma leve depressão.

Como estratégias de enfrentamento das alterações percebidas, os casais utilizaram lubrificantes vaginais, camisinha com lubrificante, estímulos de fitas pornográficas, mas, sobretudo souberam esperar o momento do outro. O uso do lubrificante vaginal foi sugerido aos parceiros pelas mulheres.

Neste período, os homens foram mais cuidadosos e evitaram procurar a esposa para o ato sexual, mas estiveram presentes no cuidado físico.

A mulher, no relacionamento sexual, se percebeu sexualmente atraente, quando foi acariciada, abraçada, acarinhada ou recebeu mais atenção, o que os homens souberam oferecer neste período.

As mulheres relataram que houve participação dos companheiros durante o tratamento e que, muitas vezes, eles não foram mais participativos porque elas não 
deixaram, afirmando que o trabalho do homem é mais importante do que acompanhá-las.

A desinformação na área da sexualidade esteve presente neste grupo de estudo, mesmo para as mulheres que freqüentaram o REMA, visto que neste espaço elas tiraram dúvidas, principalmente sobre o tratamento. Os homens tiveram menos informações do que as mulheres, mas também não fizeram o movimento de ir buscar.

Entretanto, ter um amigo ou parente da área da saúde, foi um fator que facilitou no tratamento e nas tomadas de decisão, perante as dúvidas que se apresentaram.

Acreditamos que, se o casal tiver mais informações sobre as alterações que podem vir a ocorrer na área da sexualidade, ele passará esse período com menos dúvidas, desconfortos e ansiedade.

A enfermagem deve ser estimulada a estar orientando o casal ou a mulher durante o tratamento, sobre as alterações físicas e psicológicas, que podem ocorrer na área da sexualidade, diminuindo assim a ansiedade de que esses novos sintomas possam estar relacionados ao tratamento e não ao câncer.

A criação de grupos de apoio é de extrema importância, tanto para homens como para mulheres. Entretanto, as mulheres, por já terem a experiência de freqüentar um grupo, o REMA, conseguem enxergar esse espaço como um local para sanar dúvidas, compartilhar experiências e diminuir as angústias.

Os homens relatam que um grupo informativo seria bom, mas são mais resistentes à idéia de participarem de atividades e compartilharem seus sentimentos em relação à doença da esposa, mesmo afirmando que se sentiram muito sós durante a doença da companheira. 
Os papéis de gênero, em alguns momentos, se mantiveram durante a doença, mas. em outros, foram invertidos, como por exemplo, o homem sendo o cuidador.

Observamos que a dominação masculina não se fez presente, porque os casais vinham construindo uma relação de igualdade no seu relacionamento, com uma evolução constante reproduzindo e modificando os valores do seu habitus .

Achamos que este trabalho é o início de muitos outros que poderão vir a reformular alguns conceitos da sexualidade após um diagnóstico de câncer de mama, trazendo novos conhecimentos de como os casais se reorganizam nesta área.

Este estudo ocorreu com casais que acreditavam que esse era um modo de colaborar com novos conhecimentos acerca de situações vivenciadas por mulheres que tiveram o câncer de mama e que esses novos saberes poderiam levar à diminuição do preconceito e do estigma da doença. Ao chegarmos ao término desse trabalho, esperamos que os resultados aqui encontrados sejam convertidos em estímulo para outros estudos na área da sexualidade, de casais que convivem como o câncer de mama.

Fatores como a queda dos cabelos, como efeito colateral da quimioterapia, e, conseqüentemente, como um fator depreciativo da auto-imagem se mostrou como um item que deve ser pesquisado mais profundamente, principalmente entre casais de crenças religiosas que valorizam o comprimento do cabelo feminino como um símbolo de feminilidade perante Deus.

Assim, esperamos que o enfermeiro que lida com o paciente oncológico utilize o momento do cuidado para estar orientando a mulher e a família, sobre as 
Considerações Finais

alterações de sexualidade que podem vir a ocorrer durante o tratamento do câncer de mama. 
REFERÊNCIAS 


\section{REFERÊNCIAS}

ALMEIDA, A. M. Vivendo a incerteza da doença: a experiência de mulheres com câncer de mama. 1997. 152 f. Tese (Doutorado)-Escola de Enfermagem de Ribeirão Preto. Universidade de São Paulo, Ribeirão Preto, 1997.

et al. Construindo o significado da recorrência da doença: a experiência de mulheres com câncer de mama. Rev Latino-Americana de Enfermagem, Ribeirão Preto, v. 9, n. 5, p. 63-69, 2001.

ANLLO, L. M. Sexual life after breast cancer. Journal of Sex \& Marital Therapy, v. 26, p. 241-248, 2000.

ARANTES, S. L. A participação das mulheres com câncer de mama na escolha do tratamento: um direito a ser conquistado. 2002. $1842 \mathrm{f}$. Tese (Doutorado). Escola de Enfermagem de Ribeirão Preto. Universidade de São Paulo, Ribeirão Preto, 2002.

ARENT, M. A crise do macho. In: ROSO, A. et al. (Org.). Gênero por escrito: saúde, identidade e trabalhos. Porto Alegre: EDIPUCRS, 1999. p.121-122.

ARILHA, M.; RIDENTI, S. G. U.; MEDRADO, B. (Org.). Homens e masculinidade outras palavras. São Paulo: ECOS: Ed. 34, 1998. p. 27.

AYOUB, A. C. et al. Planejando o cuidar na enfermagem oncológica. São Paulo: Lemar, 2000. $84 \mathrm{p}$.

BADINTER, E. XY: sobre a identidade masculina. 2. ed. Rio de Janeiro: Nova Fronteira, 1993. 266 p.

Um amor conquistado: o mito do amor materno. Rio de Janeiro: Nova Fronteira, 1985. $370 \mathrm{p}$. 
BERGAMASSO, R. B. O sofrimento de descobri-se com câncer de mama: como o diagnóstico é experienciado pela mulher. 1999. 119 f. Tese (Doutorado)- Escola de Enfermagem de São Paulo. Universidade de São Paulo, São Paulo, 1999.

BIDDULPH, S. Por que os homens são assim? São Paulo: Fundamento Educacional, 2003. $160 \mathrm{p}$.

BIFFI, R. G. O suporte social do parceiro sexual na reabilitação da mulher com câncer de mama - a perspectiva do casal. 1998. 130 f. Dissertação (Mestrado)Escola de Enfermagem de Ribeirão Preto, Universidade de São Paulo, Ribeirão Preto, 1998.

A dinâmica familiar de um grupo de mulheres com câncer de mama. 2003.178 f. Tese (Doutorado)-Escola de Enfermagem de Ribeirão Preto, Universidade de São Paulo, Ribeirão Preto, 2003.

BONASSA, E. M. A. Enfermagem em quimioterapia. São Paulo: Atheneu, 2000. $284 \mathrm{p}$.

BORDIEU, P. O poder simbólico. 4. ed. Rio de Janeiro: Bertrand Brasil, 2001. cap. 1, p. 7-16.

A dominação masculina revisitada. In: LINS, D. (Org.). A dominação masculina revisitada. Campinas, SP: Papirus, 1998. p. 23.

Razões práticas: sobre a teoria da ação. Campinas, SP: Papirus. 1996. p. 42.

Coisas ditas. São Paulo: Brasiliense, 1990. p. 131.

Novas reflexões sobre a dominação masculina. In: LOPES, M. J. M.; MEYER, D. E.; WALDOW, V. R. (Org.). Gênero e saúde. Porto Alegre: Artes Médicas, 1996. cap. 3, p. 36-38.

BOZON, M. Sociologia da sexualidade. Rio de Janeiro: FGV, 2004. 170 p.

BRASIL. Ministério da Saúde. Instituto Nacional do Câncer. Ações de enfermagem para o controle do câncer. Rio de Janeiro: Pró-Onco, 1995. 346 p. 
BRASIL. Ministério da Saúde. Ações de enfermagem para o controle do câncer: uma proposta de integração ensino-serviço. 2. ed. Rio de Janeiro: INCA, 2003. $376 \mathrm{p}$.

BRASIL. Ministério da Saúde. Instituto Nacional de Câncer. Estimativa 2005: incidência de câncer no Brasil. Rio de Janeiro: INCA, 2004. 94 p.

BRASIL. Ministério da Saúde. Instituto Nacional do Câncer. Câncer de mama. Disponível em: <http:/www.inca.gov.br>. Acesso em: 14 abr. 2003.

BRENTANI, M. M.; COELHO, F. R. G.; KOWALSKI, L. P. Bases da oncologia. 2. ed. São Paulo: Lemar, 2003. 452 p.

CAMARGO, M. C.; MARX, A. G. Reabilitação física no câncer de mama. São Paulo: Rocca, 2000. p. 173.

CERQUEIRA, A. A dinâmica conjugal em situação de câncer de mama. 2004. 103 f. Dissertação (Mestrado)-Programa de Pós-graduação em Psicologia da Universidade Católica de Brasília, Brasília, 2004.

CHAUÍ, M. Repressão sexual: essa nossa (des)conhecida. 7. ed. São Paulo: Brasiliense, 1994. p. 138.

CLAPIS. M. J. Qualidade de vida de mulheres com câncer de mama - uma perspectiva de gênero. 1996. 252 f. Tese (Doutorado)-Escola de Enfermagem de Ribeirão Preto. Universidade de São Paulo, Ribeirão Preto, 1996.

COLLUCCI, C. Cresce câncer da mama antes dos 35 anos. Folha de São Paulo, São Paulo, 5 jun. 2005. Cotidiano, p.1.

CORBELLINI, V. L. Câncer de mama: encontro solitário com o temor do desconhecido. Rev. Gaúcha Enferm., Porto Alegre, v. 22, p. 42-68, jan. 2001.

COSTA, M. Mulher: a conquista da liberdade e do prazer. Rio de Janeiro: Ediouro, 2004, $149 \mathrm{p}$.

DONAHOE, K. Cirurgia plástica e reconstrutiva. In: MEEKER,M. H.; ROTHROCK, J. C. (Org.). Cuidados de enfermagem ao paciente cirúrgico. 10. ed. Rio de Janeiro: Guanabara Koogan, 1997. cap. 23, p. 878-938. 
DOUSSET, M. P. Vivendo durante um câncer: livro para uso dos doentes e seus familiares. Bauru: EDUSC, 1999. 236 p.

DUARTE T. P.; ANDRADE, A. N. Enfrentando a mastectomia: análise dos relatos de mulheres mastectomizadas sobre questões ligadas à sexualidade. Estudos de Psicologia, v. 8, n. 1, p. 155-163, 2003.

ELSEN, I. Desafio da enfermagem no cuidado de famílias. In: ELSEN, I. et al. (Org.). Marcos para a prática de enfermagem com famílias. Florianópolis: UFSC, 1994. p. 69.

FERNANDES, A. F. C. O cotidiano da mulher com câncer de mama. Fortaleza: UFC, 1997. p. 80.

FERREIRA, A. B. H. Novo dicionário Aurélio da língua portuguesa. 9. ed. Rio de Janeiro: Nova Fronteira, 1986. 1168 p.

FOLGUEIRA, M. A. A. K.; BRENTANI, M. M. Receptores de estrógeno e progesterona em câncer de mama. In: BRENTANI, M. M.; COELHO F. G. C.; KOWALSKI, L. P. Bases da Oncologia. 2. ed. São Paulo: Lemar, 2003. cap. 9. p. 147-166.

FONSECA, R. M. G. Mulheres e enfermagem: uma construção generificada do saber. 1996. 202 f. Tese (Livre docência)-Escola de enfermagem de São Paulo, Universidade de São Paulo, São Paulo, 1996.

\section{FOUCAULT, M. História da sexualidade: a vontade de saber. 10. ed. Rio de Janeiro: Graal: 1988. 152 p.}

FREITAS, F. et al. Rotinas em ginecologia. 3. ed. Porto Alegre: Artes Médicas, 2001. $495 \mathrm{p}$.

FUNG, K. W. et al. The impact of mastectomy, breast-conserving treatment and immediate breast reconstruction on the quality of life of Chinese women. AZN J. Surg., v. 71, p. 202-206, 2000.

GARCIA, S. M. Conhecer os homens a partir do gênero e para além do gênero. In: ARILHA, M.; RIDENTI, S. G. U.; MEDRADO, B. (Org.). Homens e masculinidades: outras palavras. São Paulo: ECOS: Ed. 34, 1998. p. 37.

Deleted: FAGUNDES, L. A. et all. Reações psicológicas ao câncer de mama e seu 
GREGERSEN, E. Práticas sexuais: a história da sexualidade humana. Rio de Janeiro: Rocca, 1982. 297 p.

HARCOURT, D.; RUNSEY, N. Psychological aspects of breast reconstruction: a review of the literature. Journal of Advanced Nursing, v. 35, n. 4, p. 477-487, 2001.

HEILBORN, M. L. (Org.). Família e sexualidade. Rio de Janeiro: FGV, 2004. p. 70.

HOLMBERG, S. K. et al. Relations hip issues of women with breast cancer. Cancer Nursing, v. 24, n. 1, p. 53-60, 2001.

HORDEN, A. Intimacy and sexuality for woman with breast cancer. Cancer Nursing, v. 23, n. 3, p. 230-236, 2000.

HUGHES, M. K. Sexuality and the cancer survivor. Cancer Nursing, v. 23, n. 6, p. 477-482, 2000.

KAABEER, N. O que é gênero. In: SHALLAT, L. (Org.). Conceitos de gênero no planejamento e desenvolvimento: uma abordagem básica. [s.l.]: Instituto Nacional de Pesquisas e Capacitação das Nações Unidas para a promoção da mulher, 1995. p.15.

KAPLAN, H. S. Enciclopédia básica de educação sexual. Rio de Janeiro: Record, 1983. $183 \mathrm{p}$.

KOLODNY, R. C.; MASTER, W. H.; JOHNSON, V. E. Manual de medicina sexual. São Paulo: Manole, 1982. 640 p.

LAMBERT, E. Z. A face do amor: a questão da beleza e a libertação da mulher. Rio de Janeiro: Record: Rosa dos Tempos, 1996. p. 270.

LEAL, J. C. A maldição da mulher: de Eva aos dias de hoje. São Paulo: DPL, 2004. $190 \mathrm{p}$.

LEITE, R. C.; OLIVEIRA C.; RIBEIRO L. Câncer de mama: prevenção e tratamento. São Paulo: Ediouro, 2002. p. 232.

LOBO, E. S. A classe operária tem dois sexos: trabalho, dominação e resistência São Paulo: Brasiliense, 1991. p. 286. 
LOPES, G.; MAIA, M. Sexualidade e cultura - a construção dos mitos e tabus

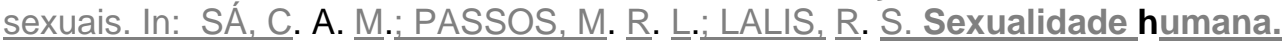
Rio de Janeiro: Revinter, 2000. 184 p.

LUDKE, M.; ANDRE, M. E. D. A. Pesquisa em educação: abordagens qualitativas. São Paulo: EPU, 1986. 123p.

MAMEDE, M. V. Reabilitação de mastectomizadas: um novo enfoque assistencial. 1991. 140 f. Tese (Doutorado)-Escola de Enfermagem de Ribeirão Preto, Universidade de São Paulo, Ribeirão Preto, 1991.

MARTINS FILHO, J. Evolução do Aleitamento materno no Brasil. In: REGO, J.D. (Org.). Aleitamento Materno. São Paulo: Atheneu, 2001. 21-34 p.

MENKE, C. G. et al. Rotinas em mastologia. Porto Alegre: Artes Médicas Sul, 2000. p. 210.

MEYEROWITZ, B. E. et al. Sexuality following breast cancer. Journal of Sex \& Marital Therapy, v. 25, n. 3, p. 237-250, 1999.

MURARO, R. M. A mulher no $3^{\circ}$ milênio. 4. ed. Rio de Janeiro: Rosa dos Tempos, 1995. $204 \mathrm{p}$.

Sexualidade da mulher brasileira: corpo e classe social no Brasil. 3. ed. Petropólis: Vozes, 1983. 501 p.

MURARO, R. M.; BOFF, L. Feminino e masculino: uma nova consciência para o encontro das diferenças. Rio de Janeiro: Sextante, 2002. p. 288.

NUCLEO DE APOIO AO PACIENTE COM CÂNCER (NAPACAN). Manual do paciente com câncer. 3 ed. [s.l.]: Sociedade Brasileira de Cancerologia. 3. ed. [2002?]. 62 p.

NOLASCO, S. O mito da masculinidade. 2. ed. Rio de Janeiro: Rocco, 1993. p 173.

OLIVEIRA, E. M. Gênero, saúde e trabalho: um olhar transversal. In: OLIVEIRA, E. M.; SCAVONE, L. (Org.). Trabalho, saúde e gênero na era da globalização. Goiânia: Ed. AB, 1997. p. 139.

OLIVEIRA, S. R. C. A sexualidade e o homem: psicopatologia, diagnóstico e tratamento dos transtornos sexuais masculinos. São Paulo: Lemos, 2000. 191 p. 
ORGANIZAÇÃO PANAMERICANA DE SAÚDE. Doenças crônico-degenerativas e obesidade: estratégia mundial sobre alimentação saudável, atividade física e saúde. Brasília, 2003. p. 39.

PANOBIANCO, M. S.; MAMEDE, M. V. Complicações e intercorrências associadas ao edema de braço nos três primeiros meses pós-mastectomia. Rev Latino-

Americana de Enfermagem, Ribeirão Preto, v. 10, n. 4, p. 544-51, 2002.

PEREIRA, V. M. Sexualidade e a formação do profissional de enfermagem: o estudo da sexualidade humana nos cursos de enfermagem no estado de São Paulo - 1997. In: GIR, E. et al. (Org.). Sexualidade em temas. Ribeirão Preto: FUNPEC-RP, 2000. cap. 8, p. 103-118.

PITCEATHLY, C.; MAGUIRE, P. The psychological impact of cancer on patients' partners and other key relatives: a review. European Journal of Cancer, v. 39, p. 1517-1524, 2003.

RAMIRES, V. R. O exercício da paternidade hoje. Rio de Janeiro: Record: Rosa dos Tempos, 1997. $121 \mathrm{p}$.

REMEN, R. N. O paciente como ser humano. São Paulo: Summus,1993. cap. 3, p. 99-127.

RIBEIRO, C. A. C. Classe e gênero no Brasil contemporâneo: mobilidade social, casamento e divisão do trabalho doméstico. In: ARAUJO, C.; SCALON, C. (Org.). Gênero, família e trabalho no Brasil. Rio de Janeiro: FGV, 2005. 304 p.

RIBEIRO, E. P. ; GRADIM C. V. C.; SILVA M. A. O auto-exame das mamas. CONGRESSO DA ESCOLA DE FARMÁCIA E ODONTOLOGIA DE ALFENAS, 1., Anais... Alfenas, 1999.

RODRIGUES D. P. Mulher mastectomizada e a sexualidade: análise do processo adaptativo. 1999. 142 f. Dissertação (Mestrado)-Faculdade de Farmácia, Odontologia e Enfermagem, Universidade Federal do Ceará, Fortaleza,1999.

ROGERS, M.; KRISTJANSON, L. J. The impact on sexual functioning of chemotherapy-induced menopause in women with breast cancer. Cancer Nursing, v. 25, n. 1, p. 57-63, 2002.

ROSENTHAL, S. H. Sexo depois dos 40. Rio de Janeiro: Ediouro, 2004. 315 p. 
ROSSI, L.; SANTOS, M. A. Repercussões psicológicas do adoecimento e tratamento em mulheres acometidas pelo câncer de mama. Psicologia Ciência e Profissão, v. 23, n. 4, p. 32-41, 2003.

SCOTT, J. Gênero uma categoria útil de análise histórica. Educação e Realidade, v. 20, n. 2, p. 69-133, jul./dez. 1995.

SCHRAIBER, L. B.; GOMES, R.; COUTO, M. T. Homens e saúde na pauta da Saúde Coletiva. Ciência e Saúde Coletiva. v. 10, n. 1, p. 7-18, 2005.

SEGAL, S. M. Desfazendo mitos: sexualidade e câncer. São Paulo: Ágora, 1994. p. 110.

SILVA, R.M. O conviver com a mastectomia. 1994. 156 f. Tese (Doutorado)-Escola de Enfermagem de Ribeirão Preto, Universidade de São Paulo, Ribeirão Preto, 1994.

SILVA, R. M.; MAMEDE, M. V. Conviver com a mastectomia. Fortaleza: UFC, 1998, $155 \mathrm{p}$.

SMELTZER, S. C.; BARE, B. G. Brunner \& Suddarth tratado de enfermagem médico-cirúrgica. 9. ed. Rio de Janeiro: Guanabara Koogan, 2002. cap. 44, p. 1232.

STRAUSS, A.; CORBIN, J. Basics of qualitative research: techniques and procedures for developing Grounded theory. Califórnia: SAGE, 1990. 270 p.

Basics of qualitative research: techniques and procedures for developing Grounded theory. 2. ed. Califórnia: SAGE, 1998. 310 p.

STRAUSS, A. L. Qualitative analyses for social scientists. Cambridge: Cambridge University, 1987. cap. 1.

STREUBERT, H. J.; CARPENTER, D. R. Qualitative research in nursing: advance the humanistic imperative. Philadelphia: J. B. Lippincott, 1995. cap. 7, p.145-161.

TELES, M. A. A. Breve histórico do feminismo no Brasil. São Paulo: Brasiliense, 1993. p. 181. 
WALDOW, V. R. Cuidado humano: o resgate necessário. Porto Alegre: Sagra Luzzatto, 1999. p. 51

WANDERLEY K. S. Aspectos psicológicos do câncer de mama. In: CARVALHO, M. M.M. J. (Coord.). Introdução à psiconcologia. São Paulo: Psy, 1994. p. 59.

WILLIANS, S.; SEED, J.; MILAU, A. Manual de formação em gênero da Oxfan. Salvador: SOS Corpo Gênero e Cidadania, 1999. 502 p.

WILMOTH, M. C. The aftermath of rest cancer: an altered sexual self. Cancer Nursing, v. 24, n. 24, p. 278-286, 2001.

YALOM, M. História do seio. Lisboa: Teorema, 1997. p. 113.

A história da esposa: da Virgem Maria a Madonna: o papel da mulher casada dos tempos bíblicos até hoje. Rio de Janeiro: Ediouro, 2002.

VALLADARES, R.; BERGAMO, G. O fim dos mitos sobre o câncer. Revista Veja, São Paulo, v. 1905, n. 20, ano 38, p. 78-96, 2005. 487 p.

VIANNA L. C.; MARTINS M.; GEBER S. Ginecologia. 2. ed .Rio de Janeiro: MEDSI, 2001. p. 822

VILAS BOAS, V. A; GRADIM, C. V. C.; DÁZIO, E. M. R. A utilização do exame preventivo de câncer de colo uterino no município de Alfenas-MG. R. Esc. Farm. Odontol. Alfenas, Alfenas, n. 24, jan./dez. 2002.

VILELA, W. V.; ARILHA, M. Sexualidade, gênero e direitos sexuais e reprodutivos. In: BERQUÓ, E. (Org). Sexo \& Vida: panorama da saúde reprodutiva. Campinas, SP: UNICAMP, 2003. p. 95-150. 
ANEXOS e APENNDICES 


\section{ANEXOS}

Anexo1
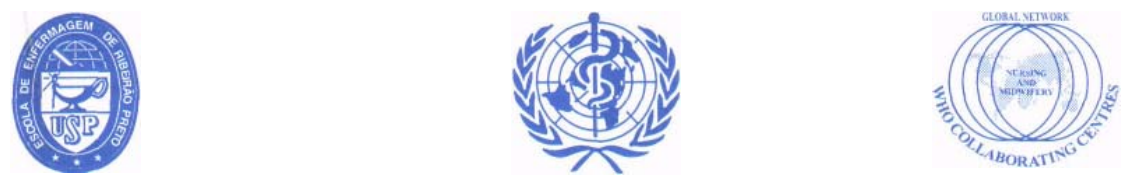

ESCOLA DE ENFERMAGEM DE RIBEIRÃO PRETO - UNIVERSIDADE DE SÃO PAULO

CENTRO COLABORADOR DA ORGANIZAÇÃO MUNDIAL DA SAÚDE PARA

O DESENVOLVIMENTO DA PESQUISA EM ENFERMAGEM

Avenida Bandeirantes, 3900 - Campus Universitário - Ribeirão Preto - CEP 14040-902 - São Paulo - Brasil

FAX: 55 - 016 - 633-3271 / 55 - 016 - 630-2561 / TELEFONES: 55 - 016 - 633-0379 / 602-3382

COMITÉ DE ÉTICA EM PESQUISA DA EERP/USP

Of.CEP-EERP/USP - 142/2002

Ribeirão Preto, 20 de dezembro de 2002.

Prezada Senhora,

Comunicamos que o projeto de pesquisa, abaixo especificado, foi analisado e considerado APROVADO pelo Comitê de Ética em Pesquisa da Escola de Enfermagem de Ribeirão Preto da Universidade de São Paulo, em sua $46^{\mathrm{a}}$ Reunião Ordinária, realizada em 19 de dezembro de 2002.

Protocolo: $n^{\circ} 0314 / 2002$

Projeto: SEXUALIDADE

MASCULINA ENTRE PARCEIROS DE MULHERES MASTECTOMIZADAS

Pesquisadores: Prof ${ }^{\mathrm{a}} \operatorname{Dr}^{\mathrm{a}}$ ANA MARIA DE ALMEIDA

CLÍCIA VALIM CORTES GRADIM

Em atendimento à Resolução 196/96, deverá ser encaminhado ao CEP o relatório final da pesquisa e a publicação de seus resultados, para acompanhamento, bem como comunicada qualquer intercorrência ou a sua interrupção.

Atenciosamente,

Prof $\mathrm{Dr}^{a}$ Maria Suely Nogueira

Vice-Coordenadora do CEP-EERP/USP

Ilma. Sra.Prof ${ }^{a}$ Dr $^{a}$ ANA MARIA DE ALMEIDA

Departamento de Enfermagem Materno-lnfantil e Saúde Pública Enfermagem de Ribeirão Preto da Universidade de ao Paulo 


\section{Anexo 2}
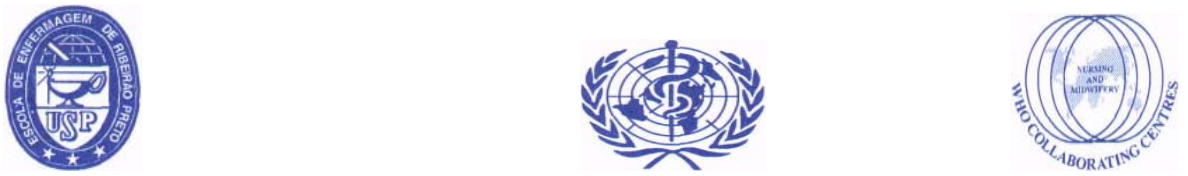

ESCOLA DE ENFERMAGEM DE RIBEIRÃO PRETO - UNIVERSIDADE DE SÃO PAULO

CENTRO COLABORADOR DA ORGANIZAÇÃO MUNDIAL DA SAÚDE PARA

O DESENVOLVIMENTO DA PESQUISA EM ENFERMAGEM

Avenida Bandeirantes, 3900 - Campus Universitário - Ribeirão Preto - CEP 14040-902 - São Paulo - Brasil FAX: 55 -16 - 633-3271 / 55 -16 - 630-2561 - TELEFONES: 55 -16 - 633-0379 / 602-3382

\section{COMITÉ DE ÉTICA EM PESQUISA DA EERP/USP}

Of.CEP-EERP/USP - 0098/2004

Ribeirão Preto, 17 de setembro de 2004

Prezada Senhora,

Comunicamos que o projeto de pesquisa, abaixo especificado, foi analisado $e$ considerado APROVADO pelo Comitê de Ética em Pesquisa da Escola de Enfermagem de Ribeirão Preto da Universidade de São Paulo, em sua $66^{a}$ Reunião Ordinária, realizada em 15 de setembro de 2004.

Protocolo: $\quad n^{\circ} 0314 / 2002$

Projeto: Sexualidade Masculina entre Parceiros de Mulheres Mastectomizadas

Pesquisadores: Ana Maria de Almeida (Orientadora)

Clícia Valim Cortes Gradim (Doutoranda)

Em atendimento à Resolução 196/96, deverá ser encaminhado ao CEP o relatório final da pesquisa e a publicação de seus resultados, para acompanhamento, bem como comunicada qualquer intercorrência ou a sua interrupção.

Atenciosamente,
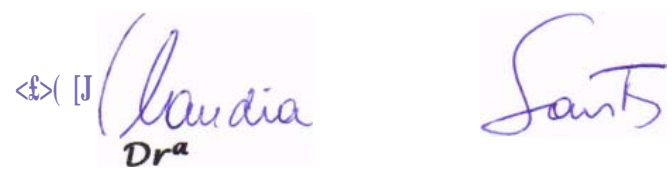

Prof*Coordenadora do CEP-EERP/USP

lima. Sra.

Prof. Or". Ana Maria de Almeida (Orientadora)

Departamento de Enfermagem Matemo-Infantil E Saúde Pública Escola de Enfermagem de Ribeirão Preto - USP 


\section{Apêndice 1}

\section{TERMO DE CONSENTIMENTO LIVRE E ESCLARECIDO}

Pesquisa: Sexualidade de casais que vivenciaram um câncer de mama.

Pesquisadora Responsável: Clícia Valim Côrtes Gradim

Orientadora: Dra. Ana Maria de Almeida

Estamos desenvolvendo um estudo sobre a sexualidade dos parceiros de mulheres com câncer de mama, com o objetivo de conhecer se a sexualidade dos companheiros destas mulheres foi modificada após a doença da esposa.

Para alcançar o objetivo, estamos propondo entrevistas individuais com parceiros das mulheres com câncer de mama que são assistidas no Núcleo de Ensino, Pesquisa e Assistência em Mulheres Mastectomizadas - REMA.

Para isso convidamos você a participar deste estudo que faz parte da primeira etapa da pesquisa, e tem como objetivo identificar quais parceiros que farão parte do estudo. Gostaríamos de esclarecer que sua participação é voluntária e você tem total liberdade para desistir, retirando seu consentimento em qualquer fase ou momento da pesquisa, não tendo, nenhum prejuízo na assistência prestada à sua pessoa, bem como a recusa d participação de seu parceiro. Garantimos que será mantidos o respeito, o sigilo e o anonimato, ou seja, o seu nome ou qualquer dado que possa identificá-la não aparecerá no trabalho. Não haverá nenhum gasto com a pesquisa, bem como não causará riscos e dano físico nem a você nem ao seu companheiro.

Tendo recebido todas as informações acima e ciente dos meus direitos, concordo em participar da pesquisa.

Ribeirão Preto, de 


\section{Apêndice 2}

\section{TERMO DE CONSENTIMENTO LIVRE E ESCLARECIDO}

Pesquisa: Sexualidade de casais que vivenciaram um câncer de mama.

Pesquisadora Responsável: Clícia Valim Côrtes Gradim

Orientadora: Dra. Ana Maria de Almeida

Estamos desenvolvendo um estudo sobre a sexualidade dos parceiros de mulheres mastectomizadas, com o objetivo de conhecer se a sexualidade dos companheiros destas mulheres foi modificada após a doença da esposa.

Para alcançar o objetivo, estamos propondo entrevistas individuais com parceiros das mulheres com câncer de mama que são assistidas no Núcleo de Ensino, Pesquisa e Assistência em Mulheres Mastectomizadas - REMA.

Para isso convidamos você a participar deste trabalho e solicitamos seu consentimento para utilizar o gravador. Gostaríamos de esclarecer que sua participação é voluntária e você tem total liberdade para desistir, retirando seu consentimento em qualquer fase ou momento da pesquisa, não tendo, nenhum prejuízo na assistência prestada à sua pessoa. Garantimos que será mantido o respeito, o sigilo e o anonimato, ou seja, o seu nome ou qualquer dado que possa identificá-lo não aparecerá no trabalho. Não haverá nenhum gasto com a pesquisa, bem como não causará riscos e dano físico nem a você nem à seu companheiro.

Tendo recebido todas as informações acima e ciente dos meus direitos, concordo em participar da pesquisa.

Ribeirão Preto, de

Assinatura do entrevistado-RG

Clícia Valim Côrtes Gradim/ 
Apêndice

\section{Apêndice 3}

\section{ROTEIRO DA ENTREVISTA SEMI-ESTRUTURADA}

IDENTIFICAÇÃO:

Nome:

Idade:

Escolaridade:

Profissão:

Religião

Endereço

Tempo de casado:

PERGUNTA NORTEADORA DA ENTREVISTA:

As atividades sexuais do casal foram alteradas em função do diagnóstico do câncer de mama?

PERGUNTAS COMPLEMENTARES:

- Que sentimentos foram despertados ao receber o diagnóstico do câncer?.

- Qual o significado da mama para você?

- Você percebeu alguma alteração sexual durante o período do tratamento ou posteriormente?

- Vocês receberam informações sobre a área da sexualidade durante o tratamento?

- O casal mantém diálogo sobre o assunto. Fale-me sobre isso.

- Você acha que se existisse um grupo informativo para homens, cujas companheiras tenham tido câncer de mama, para eles tirarem as dúvidas, eles participariam? 
Apêndice 4- Formando categorias e sub-categorias

Quadro 3 - Contextualizando o câncer de mama

\section{Gênero feminino. \\ Eu achei o nódulo. \\ Há uma coisa \\ diferente na mama. \\ Eu apalpei e achei um \\ carocinho. \\ Uma mama estava \\ maior do que a outra. \\ O carocinho tinha \\ aumentado.}
Eu nunca imaginei ouvir aquele resultado.

\section{Códigos}

\section{Gênero masculino}

Sub-categoria

Descobrindo a doença.

$\begin{array}{ll}\text { Para nós foi uma } & \text { Impacto do } \\ \text { surpresa. } & \text { diagnóstico }\end{array}$

Eu fiquei admirado.

Como tivesse sumido o chão.

A gente leva um baque.

Eu fiquei preocupada.

Eu achei que ia morrer.

O seu tempo de validade será menor.

Fusca batesse com FNM.

Queria resolver tudo do dia para noite.

Eu vou pensar em mim primeiro.

Eu não me apavorei.

Me aliviou por outro
Eu me senti fraco. A notícia do câncer foi mais forte que perder a câncer mama. O câncer ele é muito tenebroso.

O problema você tem que enfrentar.

Eu procuro falar o menos possível.
Foi doloroso e chocante.

Foi uma paulada na cabeça.

Fiquei angustiado.

Eu pensei que ela ia morrer.

Eu não aceitava. A minha atitude foi de desespero e revolta.

Sensação de Finitude e de Impotência

Contextualiza ndo o diagnóstico do câncer de mama
Atitudes perante o diagnóstico. 
lado.

A família ficou toda preocupada.

Tanto o marido como os filhos ficaram chateados.

Eles os filhos, ficaram muito ruinzinhos.

O meu dengo aumentou.
Eu fiquei indignado.

Todo mundo fica no pé, até os meninos.

Reação familiar. mama

ndo o
Contextualiza

diagnóstico do câncer de

Todo mundo ficou doente.

A família interagiu.

A família ficou mais unida.

Ela não pode abusar, pegar panelas, coisas quentes.

Arrumei uma pessoa Cuidados para limpar a casa.

Eu não deixo ela andar de ônibus.

Vem uma moça para dar uma geral na casa. Porque quem passa roupa sou eu.

Mudanças de papéis.

Ela fica sentada e eu faço o almoço.

Mudei de trabalho. Dei um jeito de parar de viajar.

Liberando-se para poder Chamei meu patrão e atender a contei. Se precisar sair, esposa. 
Quadro 4 - A mama após o câncer: um olhar

\section{Códigos}

\section{Gênero Feminino}

Gênero masculino Sub-categoria

Categoria

A mama lhe deixa mais mulher.

É parte da beleza da mulher.

Eu gosto de seios bonitos.

A mama é tudo.

É uma beleza na hora do sexo.

A primeira parte que a gente olha.

Uma mulher sem

Símbolo de

Feminilidade (Beleza, erótico e mama é horrível. amamentação)

Na relação é um órgão importante.

A gente se sente mais mulher. Eu gostava demais de amamentar.

Eu a vi amamentando meus dois filhos.

Quando me vi sem a mama, eu chorei.

Foi difícil olhar no espelho.

Foi uma parte dela

Percebendo-se

Mama que se perdeu.

Só me vejo sem a mama na hora do banho.

A sensação é a mesma.

Eu não vejo

O seio operado diferença.

Conhecendo uma ficou melhor do que o outro.

Para mim é um

Quando tirou o seio normal. tampão eu chorei.

Ninguém me falou

A gente sabe que não é dela, ela dessa nova mama. também sabe.

A sensibilidade não existe, eu sinto um frio tremendo.

Existe um tabu meu que eu vou quebrando

Eu me sinto bem devagar. nova mama. com a mama reconstruída. 


\section{Falta fazer o}

mamilo, mas não

me faz falta.

Não tem

necessidade de

ficar mutilada.

Você pode sair

sem essa

sensação de perda.

Vamos fazer uma mastectomia.

Fazer avaliação

para a

reconstrução.

A reconstrução

veio do meu

marido.

A mama ficou

muito dolorida.

Diminui de

tamanho.

Ficou inchada.

\section{Agora está}

diferente da outra.

\section{A sensibilidade} mudou.
Quando ela acordou, ela já estava com o seio.
Decidindo pela reconstrução.
Se apertar (a mama), ela sente dor..

Você vê a mulher mutilada.

Tem que ter cuidado, ela sente dor.

Eu tenho medo de machucar.

Eu toquei, eu mexi porque eu tinha necessidade.

Eu não coloquei a mão porque não tive vontade.
Percebendo

diferenças na

mama operada. Mama
O toque.

Está dolorida.

Passar a mão,

O toque. 
não teve não.

Quando o médico liberou, eu peguei na mama.

Custou ele por a mão na mama.

Ele passa a mão com cuidado.

$\mathrm{Na}$ outra mama ele faz carinho.

Ele coloca a mão na outra mama.

A gente acaricia igual as mamas.
Eu não acariciei porque eu tenho receio.

você a sua mulher mutilada.

Ela deixa tocar, mas eu tenho medo.

Tenho medo de achar alguma coisa.

Ela não deixa acariciar.
Mama

O toque. 
Anexo 6 - Formando categorias e sub-categorias

Quadro 5 - 0 exercício da sexualidade dos cônjuges que vivenciaram o câncer de mama

\section{Códigos}

\section{Gênero feminino.}

\section{Gênero masculino}

Sub-categoria

\section{Categoria}

Eu não o procuro.

Sim, eu o procuro semanalmente.

Você está a fim de fazer sexo, vai falar que está afim.

Eu procuro se eu quero.

Eu não o procuro não, fica na vontade dele.

No início do casamento, eu não o procurava.

Quando eu o procurava a casa caía.

Ele esperou numa boa.

Teve uma pausa prolongada.

Ele me respeitou pra caramba.

Tem maridos que se afastam, eu conversei com o médico.

É uma queixa comum.
Não é porque ela está doente que eu não tenho direitos à vida sexual.

Ela sabe das minhas

\section{Direito sexual.}

Sexualidade. necessidades.
Ela tem muito boa vontade.

Direito sexual.
Eu espero ela me responder sim.

Você tem que esperar o momento dela.

O abandono acaba matando a mulher.

Quando a mulher adoeceu, ele foi embora.

Se o homem abandona a mulher, ele não é homem.
Fatores que influenciaram na vida sexual.

Espera.

Abandono. 
Ela acaba me confortando.

Ela acalmava todo A força da mulher. mundo.

Ela teve força para ajudar outros que estavam na mesma situação.

Eu sou mais frágil que minha esposa.

Ela resolveu os problemas meus, os dela.

Dessa vez eu não vim para ser mãe.

Eu queria ficar bem para cuidar dos filhos.

Eu pensei no meu filho mais novo.

Eu vivi tão pouco tempo com o meu filho.

Ele vai ficar lá perdendo tempo? Não tem necessidade.

Nunca foi porque ele trabalhava.

Eu nunca quis que ele ficasse lá.

Se ele ficasse, ficaria preocupado com o trabalho.

Filhos

Ele me levava e me buscava. 
Foi sempre ele que

me levou e me

buscou.

Na quimio, ele me

levava e me

buscava.

\section{Eu estava disposta}

a te servir.

Eu nunca the

recusei.

$\mathrm{Na}$ hora que ele

vier eu aceito,

mesmo que não

esteja com

vontade.

Se você quiser

arrumar outra

pessoa para sair.

A minha esposa me liberou para arrumar outra mulher.
O cuidado em

manter a vida Sexualidade
Não sei se a $\quad$ A mulher perde a necessidade sexual ânsia de fazer do homem é maior sexo.

do que a da mulher.

Se a gente não se preocupa.

Se a gente não se esforça, ele pode
Elas (as mulheres) gosta de servir o melhor possível.

Não estou passando fome. Eu posso ficar sem comer.

O desinteresse sexual da mulher leva o homem a
O cuidado em

Papéis de Gênero manter a vida sexual. 
ter um procurar outra

relacionamento lá mulher.

fora.

Eu procurava fazer a minha parte.

Teve outra mulher, ele já aprontou muito comigo.

Eu acho que houve mudança na minha vida sexual.

Eu estou muito fria.

Eu acho que mudou.

Eu fiquei bem mais fria.

A primeira
dificuldade na área
sexual foi na
quimioterapia.

Eu tive

ressecamento vaginal.

Durante a quimioterapia a menstruação

parou.

O ressecamento eu preveni usando um lubrificante.

A gente usou um creme no negócio para umedecer mais.

Eu senti a diferença quando comecei a tomar o tamoxifeno.

vezes dói. na lubrificação vaginal.

Ela queixou que estava áspero, ardendo.

A gente usa um produto de lubrificação.

\section{Está ressecado?} Vamos comprar uns cremes. procura
mulher.

Eu nunca arrumei outra mulher, nunca traí.

\section{Durante o} tratamento ela não esteve disposta para o sexo.

Fica sem tesão por causa do tratamento.

Ela ficou Alterada.

Sexualidade.
Traição

Ela teve dificuldade

\section{Papéis de Gênero}


O médico deu um gel para usar no relacionamento. Eu não deixei de fazer sexo de jeito nenhum.

Durante a quimioterapia, o meu desejo diminuiu.

Durante a quimioterapia, eu tinha mais vontade de ter relação sexual. Meu desejo era maior.

Eu até tinha desejo mas não ficava aquela lubrificação certa.

Umas três semanas depois a gente começou a fazer sexo.

Eu me lembro que demorou bastante.

A gente foi
voltando a ter
relações sexuais
devagarinho.
Eu não invento
desculpas para não
transar e eu falo
para ele.

A minha sexualidade não ficou afetada.

Do meu lado não mudou nada.

A gente leva como pode levar.

A minha sexualidade não foi alterada.

A nossa atração, o nosso magnetismo, nunca se perdeu, nunca parou.

O desejo não afetou nada em mim.

Se eu pensar no que ela passou, eu perco todo o desejo.

Havia carícias, mas eu deixei por conta dela.

Em torno de um mês, quando ela se Reinício sentiu melhor.

Ficamos mais de um ano sem ter relação.

Nós sempre nos demos bem, conversando não gosto disso, não gosto daquilo.
Não alterada.

\section{Desejo Sexual. Sexualidade.}


Diálogo a gente sempre teve.

Durante a doença a gente conversava muito. $\mathrm{Na}$ área sexual não. a sexualidade
Eu estou mais

velha e ele também. O dia que a gente faz (sexo) faz bem feito.

Eu já senti que está mudando e ele falou: Você sentiu que está mudando?

Eu acho que nós estamos envelhecendo juntos.

O caminho é esse envelhecer juntos.

Deixar de deitar no ombro dele, do lado esquerdo faz muita falta.
Lá em casa é tudo também.

Não, eu sempre fui

Não precisa conversar, a gente

Envelhecer.

Sexualidade. muito conversado, quietão, a gente sempre se entendeu. se dá bem e eu tenho vergonha.

Você faz menos, mas faz a mesma coisa.

Diálogo. sa tão não percebe.
A gente faz a posição mais confortável para ela.

A gente procura uma posição que não machuque o braço.

Não houve mudanças após a cirurgia.

\section{Posições e \\ Adaptações.}


Eu pedia para usar camisinha porque ela tem lubrificante.

Eu voltei a utilizar essa posição (a mulher por cima).

É uma posição boa, porque o homem não faz pressão.

A questão de como vai segurar, não apertar, não fazer força na região da mama no abraço e apertar.

A gente acabou se adaptando, mas acrescentou o cuidado.

Às vezes a gente falava, essa posição é melhor. Esse jeito é melhor. Eu não me envergonho não, troco de roupa na frente.

Eu nunca pensei, vou tirar o sutiã e ele vai ver.

A gente toma banho junto.

Eu fico nua perto do marido, porque eu acho que não tirei a mama. O dia que eu percebi o cabelo caindo eu chorei.

$$
\begin{aligned}
& \text { desesperado, falta } \\
& \text { alguma coisa. }
\end{aligned}
$$

Para mim é como se nela, eu lavava.
A gente usa um

produto de

A gente toma

A gente assistia fita

Não mudava, eu sempre por cima.

\section{Posições e}

Adaptações.$$
\text { A gente fica triste }
$$

Ficar nu? A gente

fica.

A gente toma banho junto.

Eu dava banho

Ela sempre me impôs essa situação.

Queda dos cabelos.
Nudez

Sexualidade. 
cabelo caiu, passava

o pente e caía

aquele monte.

Ele (o cabelo) caiu.

Ele chegava de manhã e acabava rolando ali mesmo.

Procuramos mudar o horário.

Não me falaram que ia parar a menstruação. Não me orientaram e eu fiquei preocupada.

O médico nunca tocou no assunto sexualidade. A gente tem muita dúvida.

A gente fica pensando o que pode e o que não pode.

O que eu tive que perguntar foi para vocês no REMA.

Eu acho que meu marido não iria.

Eu acho difícil o homem querer ir.

Com o meu marido eu acho que funcionaria. nada tivesse acontecido, eu não sinto a diferença.

\section{Espaço Físico.}

Não eu não recebi, o médico nunca se preocupou em dar nenhuma orientação sobre 0

relacionamento.

Eu sempre tive vontade de perguntar.

Falta de Informação.

Sexualidade

Orientações nesse

sentido, não.

As dúvidas que a gente tinha, ela tirava no REMA.

Pode ser necessário difícil é achar quem vai. Homem não tem espírito familiar.

Eu acho difícil, pegar um homem sozinho já é duro.

Grupo de homens?

Grupo de Homens. Sexualidade Acho que funcionaria sim.

Devia existir um REMA para os homens. 